\title{
norden
}

\section{Framing a Nordic IPBES-like study}

Introductory Study including Scoping for a Nordic Assessment of

Biodiversity and Ecosystem Services, based on IPBES methods and procedures

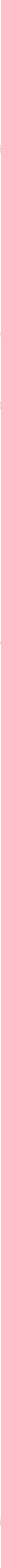







\section{Framing a Nordic IPBES-like study}

Introductory Study including Scoping for a Nordic Assessment of Biodiversity and Ecosystem Services, based on IPBES methods and procedures

Maria Schultz, Maija Häggblom, Cecilia Lindblad, Eva Roth, Sigurdur Thrainsson, Petteri Vihervaara and Nina Vik 


\section{Framing a Nordic IPBES-like study}

Introductory Study including Scoping for a Nordic Assessment of Biodiversity and Ecosystem Services, based on IPBES methods and procedures

Maria Schultz, Maija Häggblom, Cecilia Lindblad, Eva Roth, Sigurdur Thrainsson,

Petteri Vihervaara and Nina Vik

ISBN 978-92-893-4564-4 (PRINT)

ISBN 978-92-893-4565-1 (PDF)

ISBN 978-92-893-4566-8 (EPUB)

http://dx.doi.org/10.6027/TN2016-525

TemaNord 2016:525

ISSN 0908-6692

(C) Nordic Council of Ministers 2016

Layout: Hanne Lebech

Cover photo: Norden.org - Johannes Jansson, Silje Bergum Kinsten and Yadid Levy

Print: Rosendahls-Schultz Grafisk

Copies: 100

Printed in Denmark

This publication has been published with financial support by the Nordic Council of Ministers. However, the contents of this publication do not necessarily reflect the views, policies or recommendations of the Nordic Council of Ministers.

www.norden.org/nordpub

Nordic co-operation

Nordic co-operation is one of the world's most extensive forms of regional collaboration, involving Denmark, Finland, Iceland, Norway, Sweden, and the Faroe Islands, Greenland, and Åland.

Nordic co-operation has firm traditions in politics, the economy, and culture. It plays an important role in European and international collaboration, and aims at creating a strong Nordic community in a strong Europe.

Nordic co-operation seeks to safeguard Nordic and regional interests and principles in the global community. Common Nordic values help the region solidify its position as one of the world's most innovative and competitive.

Nordic Council of Ministers

Ved Stranden 18

DK-1061 Copenhagen K

Phone (+45) 33960200

\section{www.norden.org}




\section{Contents}

Framing a Nordic IPBES-like study ................................................................................. 7

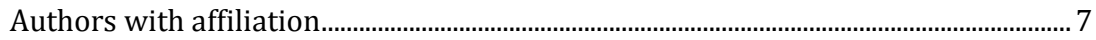

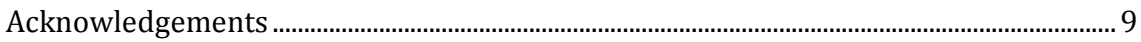

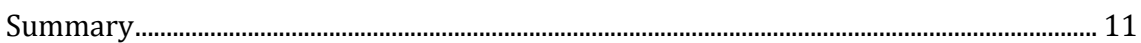

A. Background to this Introductory Study including Scoping................................... 11

B. Scope, Geographical Boundary, Rationale, Utility and Assumptions ................... 13

C. The Knowledge Base ............................................................................................................ 14

D. Organisation of Work, Time Plan and Budget.......................................................... 15

E. Conclusion of the Introductory Study including Scoping, and Way Forward ... 15

Background and introduction .............................................................................................. 17

Rising anthropogenic pressures on the world's ecosystems .................................... 17

1. SECTION I. Introductory Study including Scoping - Process, Method and

Discussion ...................................................................................................................... 29

$1.1 \quad$ Background, Process and Method …………….................................................... 29

1.2 Result of Introductory Study including Scoping............................................... 34

1.3 Discussion - Introductory Study including Scoping......................................... 35

1.4 Conclusions - Introductory Study including Scoping ...................................... 39

2. Section II. Introductory Study and Project Plan - including chapter outline ......... 41

$2.1 \quad$ Introduction ........................................................................................................ 41

2.2 Nordic Assessment - Scope, geographic boundary, rationale, utility and assumptions ............................................................................................................. 42

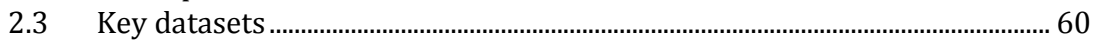

2.4 Citizen science and Indigenous and Local Knowledge systems..................... 63

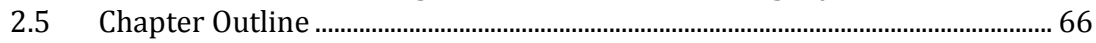

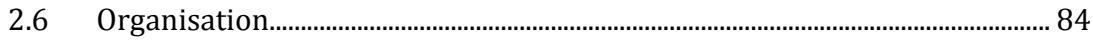

$2.7 \quad$ Budget..................................................................................................................... 98

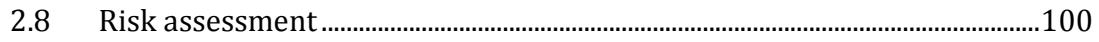

References...........................................................................................................................103

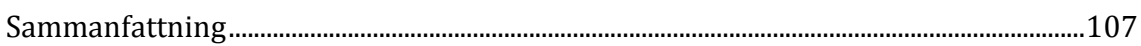

Bakgrund .......................................................................................................................107

Omfattning, geografisk avgränsning, logisk grund, nytta och antaganden ...........108

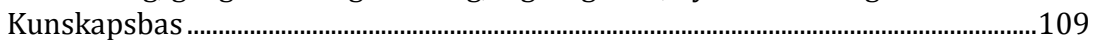

Arbetsorganisation, tidplan och budget ..................................................................110

Slutsats av förstudien, och vägen framåt..................................................................111 
Annex 1. Indigenous and Local Knowledge

Summary of report from Assignment to NAPTEK on Indigenous and Local

Knowledge in a Nordic Assessment.

Results from the ILK study.

Annex 2. Examples of processes, literature and data sources (more information available in Excel files, available upon request from SEPA)

Annex 3. Examples of National bills and commitments, Regional and other Agreements (more information available in Excel files, available upon request from SEPA).

Annex 4. Examples of potential Strategic Partners and Roster of Experts (more information available in Excel files, available upon request from SEPA)

Annex 5. Potential Nordic Hubs, contributing to sub-assessments of the Nordic Assessment of Biodiversity and Ecosystem Services (more information available in Excel files, available upon request from SEPA) ......................................................157

Annex 6. Examples of possible funding sources..............................................................161

Annex 7. IPBES processes......................................................................................................165

Annex 8. Aichi Biodiversity Targets ……………..............................................................183

Annex 9. Abbreviations and Glossary ...............................................................................187

Abbreviations .....................................................................................................................18

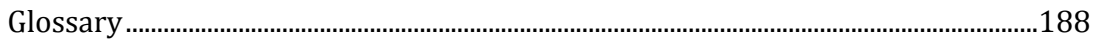




\section{Framing a Nordic IPBES-like study}

Introductory Study including Scoping for a Nordic Assessment of Biodiversity and Ecosystem Services, based on IPBES methods and procedures.

\section{Authors with affiliation}

- Maria Schultz, Project leader, Swedish Environmental Protection Agency (normally at Stockholm Resilience Centre).

Project group members selected by individual Nordic countries:

- Maija Häggblom, Department of Social Affairs, Health and Environment, Government of Åland.

- Cecilia Lindblad, Senior Adviser, Research and Assessment Department, Swedish Environmental Protection Agency, Sweden.

- Eva Roth, Associate Professor, Department of Environmental and Business Economics, University of Southern Denmark.

- Sigurdur Thrainsson, Head of Division, Ministry for the Environment and Natural Resources, Department of Land and Natural Heritage, Government of Iceland.

- Petteri Vihervaara, Adjunct Professor, Finnish Environment Institute (SYKE), Finland.

- Nina Vik, Senior Adviser, Global Biodiversity Section, Norwegian Environment Agency, Norway.

With contributions from Torbjörn Ebenhard, Erik Andersson, Håkan Tunón and many others. 



\section{Acknowledgements}

Many people have contributed to the scoping (but do not necessarily agree with all parts of it). We would like to thank in particular the reviewers Inge Thaulow, Special Advisor on international environmental affairs, Government of Greenland; Tom Christensen, Aarhus University; Marie Stenseke from Gothenburg University and co-chair of IPBES Multidiciplinary Expert Panel; Jari Niemelä, Professor, Dean, Faculty of Biological and Environmental Sciences Dept of Environmental Sciences, University of Helsinki; Ivar Baste, Senior Advisor, Norwegian Environment Agency and member of IPBES Bureau. We would also like to express special thanks to contributors such as Tom Barry, Executive Secretary, Conservation of Arctic Flora and Fauna (CAFF), Arctic Council Working Group, Torbjörn Ebenhard and Håkan Tunón from the Swedish Biodiversity Centre; Erik Andersson from Stockholm Resilience Centre; Mette Gervin Damsgaard, Ministry of the Environment Denmark; Bengt-Gunnar Jonsson, Mid-Sweden University; Mark Marissink, Swedish Environmental Protection Agency; and Laila Rehnfeldt from the Sami Parliament of Sweden; also Inkeri Ahonen, Government of Åland; Gunnar Austrheim, Norwegian University of Science and Technology; Trausti Baldursson, Icelandic Institute of Natural History; Lene Buhl-Mortensen, Institute for Marine Research; Daniele Crimella, Stockholm Resilience Centre; Marie Kvarnström, Swedish Biodiversity Centre; Berit Köhler, Norwegian Institute for Nature Research; Svein Mathiesen, Professor, International Centre for Reindeer Husbandry; Pernilla Malmer, Swedish Biodiversity Centre; Viveca Mellegård, Stockholm Resilience Centre; Ashley Perl, Stockholm Resilience Centre; and members of the Swedish Scientific Council for Biodiversity and Ecosystem Services. 



\section{Summary}

\section{A. Background to this Introductory Study including Scoping}

The 2030 Agenda for Sustainable Development recognises that natural resource depletion and adverse impacts from environmental degradation, including loss of biodiversity, add to and exacerbate the list of challenges which humanity faces. Biodiversity is well recognised in the Sustainable Development Goals, not just in Target 15 on Ecosystem and Biodiversity and Target 14 on Oceans, but integrated across all 17 goals and 169 targets, emphasising that biodiversity is fundamental to human wellbeing (UN, 2015).

According to the Global Biodiversity Outlook 3 (CBD 2010), species at risk of extinction are, on average, moving closer to extinction. Nearly a quarter of plant species are estimated to be threatened with extinction. Crop and livestock genetic diversity continues to decline in agricultural systems, as well as traditional knowledge, innovations and practices associated with biodiversity and ecosystem services (CBD, 2010); (CBD, 2014).

In order to address these challenges, adequate local, national and international policies need to be adopted and implemented. To achieve this, decision makers need credible and independent information from scientists, as well as other knowledge systems that take into account the complex relationships between biodiversity, ecosystem services and people. To meet these needs the "Intergovernmental Science-Policy Platform on Biodiversity and Ecosystem Services" (IPBES) was established in April 2012, as an independent intergovernmental body open to all member countries of the United Nations. Its purpose is to assess the state of the planet's biodiversity, its ecosystems and essential services they provide for human well-being. IPBES provides a mechanism, recognised by both the scientific and policy communities, to synthesise, review, assess and critically evaluate relevant information and knowledge generated worldwide by governments, academia, scientific organisations, non-governmental organisations, indigenous peoples and local communities. 
At a Nordic meeting in Stockholm 2014, it was proposed that a Nordic Assessment on Biodiversity and Ecosystem Services should be conducted. The assessment would be inspired and informed by IPBES, and the best way to prepare for such an assessment was judged to be through a thorough introductory study, including scoping. A proposal prepared by the Swedish Environmental Protection Agency (SEPA) was sent to the Nordic Council of Ministers, which approved DKK 450,000 for the "Scoping study Nordic Assessment to feed into IPBES", to be performed during 2015. The project group consisted of a group of representatives from the Nordic countries, selected by each Nordic country's government agencies. Consultations took place through two questionnaires, a Nordic meeting and country consultations. A study related to indigenous and local knowledge was performed in conjunction with this introductory study, including scoping, and was financed by the Swedish Environmental Protection Agency and assigned to the NAPTEK programme at Swedish Biodiversity Centre. It resulted in the "Report from the project: Indigenous and Local Knowledge in a Scoping Study for a Nordic IPBES Assessment" (Tunón et al., 2015) and an integrated approach to the issue in the Nordic introductory study including scoping.

This document is the result of the Introductory Study including Scoping for a Nordic Assessment of Biodiversity and Ecosystem Services based on IPBES methods and procedures. It is divided into: Section I, which includes a description of process and method and a discussion; and Section II, which includes the introductory study and suggested project plan for a full Nordic Assessment of Biodiversity and Ecosystem Services based on IPBES methods and procedures. This study has developed a methodology for how an assessment can be planned and performed in a sub-regional setting such as the Nordic countries, but still based on IPBES methods and procedures. It has identified actors that potentially can contribute to the full assessment, data and knowledge sources and gaps, and also identified key questions for a full Nordic Assessment. This document can also be used for proposals for the full Nordic Assessment. This version is an abridged version to be published as a TemaNord report; the full working document can be accessed via SEPA or the project leader, Maria Schultz at Stockholm Resilience Centre. 


\section{B. Scope, Geographical Boundary, Rationale, Utility and Assumptions}

The objective of the Nordic Assessment of Biodiversity and Ecosystem Services based on IPBES methods and procedures should be to strengthen the science-policy interface for biodiversity and ecosystem services for conservation and sustainable use of biodiversity, long-term human wellbeing and sustainable development at a Nordic level, as well as to feed in results to the IPBES assessment of Europe and Central Asia (ECA).

The overall scope of the Nordic Assessment should be to assess issues of relevance in a Nordic context, such as common natural resource use, for example marine areas, mountain areas, agriculture and land use activities that affect the habitats of species across borders, or ecosystem services; common drivers in Nordic countries, such as land use change, that could affect habitats, biodiversity and ecosystems in the whole region; common cultural and behavioural aspects, such as outdoor nature activities; common similarities regarding responses, such as governance aspects specific to the Nordic region, such as the fiscal system; and governance system interactions, such as how one country's governance might affect the whole region, or how Nordic governance structures of the commons could be better linked.

The Nordic region comprises Denmark, Finland, Iceland, Norway, Sweden, the Faroe Islands, Greenland and Åland. It is important to keep in mind that although there are many similarities across Nordic countries, they are highly diverse with respect to natural resource use. This can be illustrated through a number of examples. For instance, Denmark is mostly characterised by agriculture, with over $65 \%$ of its area allocated to agriculture, whereas in Iceland only $1 \%$ of the land area is cultivated; in Finland and Sweden forests take up 57\% and 54\% of the surface area, respectively, compared to Denmark where forest cover is only $9 \%$ (Kettunen, 2012). Finland and Sweden together account for $12.8 \%$ of world production of wood pulp, which is a major export item for these two countries (Nordic Council of Ministers, 2014). In Iceland, the Faroe Islands and Greenland fisheries are the dominant industry, both with respect to production and exports - in the Faroe Islands almost $89 \%$ of export value stems from fishing and in Greenland 63\%; in Iceland, it is close to $39 \%$, compared to Denmark and Norway with about 3-4\% and 6-7\% respectively (Nordic Council of Ministers, 2014). 
The Nordic Assessment should use the IPBES conceptual framework, IPBES guidelines and methodology and the outline of IPBES regional and subregional assessments as closely as possible. The assessment should consider different scales such as local, national and Nordic, and the links to international scales. For some aspects, national or local border division in accordance with political and management systems are appropriate. However, for other aspects, biogeographical regions might be more appropriate, to capture cross-border and interconnected issues relevant to biodiversity and ecosystem services. The Nordic Assessment also needs to work in synergy with other assessments such as the EU initiatives MAES (Mapping and Assessment of Ecosystems and their Services) and ESMERALDA (Enhancing ecoSysteM sERvices mApping for poLicy and Decision mAking).

\section{The Knowledge Base}

The Nordic Assessment should use existing knowledge and data held by global, regional, Nordic and national institutions, such as scientific literature, and other information, including citizen science, indigenous and local knowledge. Information should be gathered from published literature, including grey literature, in accordance with guidelines of the IPBES Platform, and also through, for example, national academies of science, national research institutes, scientific societies and other research communities, government environmental agencies and statistical agencies. The consideration of specific Nordic knowledge and metadata should be discussed early in the assessment process. It will be of importance to assess the added value of such an effort and to avoid unnecessary duplication of existing or on-going work.

The Chapter Outline suggests following the IPBES Regional and Sub-regional Assessments Structure, which comprises: Chapter 1: Setting the scene; Chapter 2: Ecosystem services and human well-being - (Nature's benefits to people and Good quality of life); Chapter 3: Status, trends and future dynamics of biodiversity and ecosystems underpinning nature's benefits to people; Chapter 4: Direct and indirect drivers of change in the context of different perspectives of human well-being (quality of life); Chapter 5: Integrated and cross-scale analysis of interactions of nature and human society; and Chapter 6: Options for governance, institutional arrangements and private and public decision making across scales and sectors. 


\section{Organisation of Work, Time Plan and Budget}

A secretariat with part-time staff (applied for in a proposal to the Nordic Council of Ministers) at the Swedish Environmental Protection Agency could facilitate organising the work of the Nordic Assessment from early 2016. If more funds are available, one full-time position would be preferred. The project should be overseen by a Steering Committee, which could consist of representatives from national agencies or ministries, selected by the Nordic governments, and should decide on any strategic issues that arise during the project. An Expert Committee should be formed, consisting of scientists and other knowledge holders, based on nominations and approved by the Steering Committee. Nominations of authors should follow the IPBES rules of procedure. The Nordic Assessment could be organised in several sub-assessments with lead institutions/hubs in the Nordic countries, supporting selected authors, which could correspond to the specified main focus issues. The suggestion for the organisation of the Nordic Assessment is described in detail in Section II of this study. The assessment is planned to take place between 2016 and 2018, and the minimum budget is DKK 450,000 per year, excluding contributions from scientists and other knowledge holders.

\section{E. Conclusion of the Introductory Study including Scoping, and Way Forward}

This Introductory Study including Scoping for a Nordic Assessment of Biodiversity and Ecosystem Services based on IPBES methods and procedures, has shown a potential path towards establishing a Nordic Assessment using a pragmatic approach by considering the structure of decision-making bodies in a Nordic context, and the limitations of funding.

There are still three major questions to answer:

- The introductory study has not specified the focus for the Nordic Assessment of Biodiversity and Ecosystem Services. The choice is between an overall and general assessment in line with the generic scoping documents for the regional and sub-regional assessments of biodiversity and ecosystem services under IPBES; or focusing on a topic, such as the link between biodiversity, ecosystems, and ecosystem services they provide, and "valuation of ecosystem services" for mainstreaming and sustainable use; or on a specific ecosystem, such as marine, coastal and wetland ecosystems or 
forests. This will have to be decided at the beginning of the assessment.

- The process for deciding on the scope has to be defined. A pragmatic way would be to create a board representing the Nordic government authorities, and explore the possibility of a start-up workshop under the auspices of the Nordic Council of Ministers.

- Finding funding for broad participation in the work carried out in the Nordic Assessment is a challenge.

Furthermore, the feasibility of a Nordic Assessment is dependent on the buy-in and commitment from the Nordic countries governments, with respect to both funding and use of the assessment.

There are still challenges to be solved for the establishment of a Nordic Assessment of Biodiversity and Ecosystem Services based on IPBES methods and procedures, but if established it may contribute to meeting the urgent need to halt the loss of biodiversity, and to increasing the understanding of biodiversity, ecosystems and the links to human well-being. 


\title{
Background and introduction
}

\author{
Rising anthropogenic pressures on the world's \\ ecosystems
}

The Anthropocene (a term commonly used to define the massive, global impact of humans on the planet's biophysical processes affecting, for example, the climate and ecosystems) has generated global environmental changes with potential thresholds and tipping points, currently challenging future well-being of the human population on Earth (Rockström et al., 2009). The Planetary Boundaries framework identifies a set of nine planetary boundaries within which humanity can continue to develop and thrive for generations to come. However, crossing these boundaries could generate abrupt and irreversible environmental changes (Rockström et al., 2009). Four of the boundaries have now been crossed as a result of human activity: climate change, loss of biosphere integrity, land-system change and altered biogeochemical cycles (phosphorus and nitrogen) (W. Steffen et al., 2015). Oxfam has taken the planetary boundary idea and added social boundaries, and argued that just as the planet provides biophysical limits, the world has critical social foundations below which people should not live, based on human rights, poverty alleviation and equity aspects (Raworth, 2012).

The 2030 Agenda for Sustainable Development recognises that natural resource depletion and adverse impacts of environmental degradation, including loss of biodiversity, add to and exacerbate the list of challenges which humanity faces. Biodiversity is well recognised in the Sustainable Development Goals, not just in Target 15 on Ecosystem and Biodiversity and Target 14 on Oceans, but integrated across the 17 goals and 169 targets, acknowledging that biodiversity is fundamental to human well-being (UN, 2015). 


\section{Ecosystems and good quality of life - interlinked social-ecological systems}

With long term sustainability in mind, human development must be reconnected to operate within the capacity of the biosphere and essential ecosystem services (Folke et al., 2011). Biodiversity provides the basis for ecosystem functions and services, which also underpins human well-being. For instance, biodiversity can promote ecosystem-based adaptations to climate change, and nature-based solutions to sustainable development. However, biodiversity and ecosystem services are declining at an unprecedented rate.

Biological diversity means the variability among living organisms from different ecosystems; such as, inter alia, terrestrial, marine and other aquatic ecosystems; and the ecological complexes of which they are part; which includes diversity within species, between species and of ecosystems. ${ }^{1}$

The term ecosystem services describes the ecosystems' direct and indirect contributions to human well-being. More visible ecosystem services, such as the production of food and fibres (goods), both affect and depend on other services, such as soil formation and nutrient and water regulation. Cultural ecosystem services contribute through inspiration, recreation, beauty and spiritual values to our well-being. (Schultz, 2013)

According to the Global Biodiversity Outlook 3 (CBD 2010), species at risk of extinction are, on average, moving closer to extinction. Nearly a quarter of plant species are estimated to be threatened with extinction. Crop and livestock genetic diversity continue to decline in agricultural systems, as well as traditional knowledge, innovations and practices associated with biodiversity and ecosystem services. Since the agreement of the Strategic Plan on Biodiversity under the Convention on Biological Diversity (CBD) in 2010, encouraging steps have been taken around the world to tackle biodiversity loss. Nevertheless, it is clear that the current trajectory will not be sufficient to meet most of the Aichi Biodiversity Targets of the CBD Strategic Plan by the commitment deadlines ${ }^{2}$ (CBD, 2010)(CBD, 2014).

\footnotetext{
${ }^{1}$ Convention on Biological Diversity, Article 2. Use of Terms.

${ }^{2}$ The Strategic Plan for Biodiversity 2011-2020 represents a universally agreed framework for action on biodiversity and a foundation for sustainable development for all stakeholders, including agencies across the United Nations system. The 2050 Vision of the Strategic Plan is for biodiversity to be valued, conserved, restored and wisely used, maintaining ecosystem services, sustaining a healthy planet and delivering benefits essential for all people. The 20 internationally agreed time-bound targets of the Strategic Plan, mainly for 2020 , are organised under five goals to meet the 2050 vision.
} 
The Earth's biological resources are vital to the economic and social development of humanity. Policy and decision makers need to be aware of the importance of biodiversity for human well-being. The educational task of explaining the links between healthy ecosystems and opportunities they provide is crucial in times of unprecedented global social, environmental and climatic change. There is a need to explore, understand and express the importance of biodiversity in interlinked social-ecological systems.

\section{Knowledge for policy and management}

In order to address the above challenges, adequate local, national and international policies need to be adopted and implemented. To achieve this, decision makers need credible and independent information from scientists, as well as from other knowledge systems, that take into account the complex relationships between biodiversity, ecosystem services and people. They also need effective methods to interpret this information in order to make informed decisions. The scientific community must also understand the needs of decision makers in order to provide them with the relevant information. In essence, the dialogue regarding biodiversity and ecosystem services between the scientific community, governments, practitioners, citizens, including indigenous and local communities, and other actors needs to be strengthened.

To meet these needs, a new platform was established 2012 by the international community - the "Intergovernmental Science-Policy Platform on Biodiversity and Ecosystem Services" (IPBES) - an independent intergovernmental body open to all member countries of the United Nations. IPBES now has 124 members. The development of IPBES started in 2005 through the Millennium Ecosystem Assessment (MA) follow-up process and the consultative process on an International Mechanism of Scientific Expertise on Biodiversity (IMoSEB). IPBES is to biodiversity and ecosystem services what IPCC (Intergovernmental Panel on Climate Change) is to climate. The members are committed to building IPBES as the leading intergovernmental body for assessing the state of the planet's biodiversity, its ecosystems, and essential services they provide for human wellbeing. Delegates of the Plenary of IPBES have elected an IPBES Chair, a Bureau and a Multidisciplinary Expert Panel (MEP). For goals, functions, objective and deliverables of IPBES, see Annex 7 Box 1. For the IPBES conceptual framework, see Figure 5. 
IPBES provides a highly structured social process for advancing science-policy practices, and also assessment processes, which are characterised as being credible, legitimate and relevant. To achieve these characteristics, an IPBES assessment typically goes through several structured stages: 1) the scoping phase, 2) the critical evaluation of the state of knowledge by selected experts, including synthesising the key findings and their confidence levels for policy-makers; 3) two rounds of peer review, one of which includes a review by policy makers; and 4) approval of the policy and relevant key findings. Relevant information to be assessed includes published literature generated worldwide by governments, academia, scientific organisations, non-governmental organisations, indigenous peoples and local communities. This involves a credible group of experts who conduct assessments of such information and knowledge in a transparent way. IPBES is unique in that it aims to strengthen the capacity of the effective use of science, and other knowledge systems, in decisionmaking at all levels. IPBES also aims to address the needs of multilateral environmental agreements related to biodiversity and ecosystem services, as well as building on existing processes to ensure synergy in each other's work. Besides thematic assessments, such as an assessment of pollination, the IPBES has decided to conduct regional and sub-regional assessments of biodiversity and ecosystem services, which aim to contribute to the development of the regions and to feed into a global assessment by 2018 . See further information at: http://ipbes.net/

\section{Nordic Scoping}

The Nordic countries have collaborated in IPBES-related work with support from the Nordic Council of Ministers. With this introductory and scoping study, Nordic country participants have explored the potential of a sub-regional assessment - a Nordic Assessment, that could give the issue more weight within the region's countries, and feed into the regional assessment for Europe and Central Asia, and ultimately into the Global IPBES Assessment.

\section{Brief facts - The Nordic Region and biodiversity and ecosystem services.}

Information and statistics, such as the Nordic statistical yearbook, and facts about the Nordic region and Nordic cooperation can be found at the website www.norden.org. See Table 1 for data on land use and population density 
in the Nordic countries. The Nordic region comprises Denmark, Finland, Iceland, Norway, Sweden, the Faroe Islands, Greenland and Åland.

The Faroe Islands are formally part of the Kingdom of Denmark, but enjoy extensive autonomy. The Faroe Islands are not a member of the European Union (EU), but have entered into a fisheries and trading agreement with the EU. Greenland is part of the Kingdom of Denmark but has a high degree of self-governance. Greenland is not a member of the EU, but also has a special fisheries agreement with EU, and has been accepted as one of the overseas countries or territories with a special association with the EU. Åland is part of the Republic of Finland, but has a high degree of self-governance, its own devolved parliament and its own legislation in many areas (e.g. environment, trade and industry). For autonomous regions and self-governing regions see Figure 7. Iceland and Norway are not members of the EU, but take part in European economic co-operation through the EEA Agreement ${ }^{3}$ (www.norden.org).

The geographical boundaries with maps of the Nordic region are described in Section II B "Geographic boundary of the assessment".

\begin{tabular}{|c|c|c|c|c|c|c|c|c|}
\hline $\begin{array}{l}\text { Land use and } \\
\text { density. } 2013\end{array}$ & Denmark & $\begin{array}{l}\text { Faroe } \\
\text { Islands }\end{array}$ & Greenland & Finland & Åland & Iceland & Norway & Sweden \\
\hline Total area, sq km & 43,571 & 1,396 & $2,166,086$ & 338,432 & 1,580 & 103,492 & 323,771 & 447,420 \\
\hline Total area & 100.00 & 100.00 & 100.00 & 100.00 & 100.00 & 100.00 & 100.00 & 100.00 \\
\hline $\begin{array}{l}\text { Arable land and gar- } \\
\text { dens }\end{array}$ & 58.1 & 0.0 & 0.0 & 6.8 & 8.9 & 1.2 & 2.5 & 5.8 \\
\hline $\begin{array}{l}\text { Meadows and pas- } \\
\text { tures }\end{array}$ & 8.2 & 0.0 & 0.0 & 0.1 & 3.4 & 16.9 & 0.5 & 1.0 \\
\hline Forests & 12.2 & 0.0 & 0.0 & 67.3 & 59.3 & 1.8 & 38.7 & 63.5 \\
\hline Other land area & 20.0 & 99.4 & 18.9 & 15.5 & 26.8 & 66.7 & 51.7 & 21.1 \\
\hline Lakes & 1.5 & 0.6 & 0.0 & 10.2 & 1.7 & 2.3 & 5.7 & 9.0 \\
\hline Icecap areas & - & - & 81.1 & - & - & 10.2 & 0.9 & 0.1 \\
\hline Population & $5,627,235$ & 48,228 & 56,282 & $5,451,270$ & 28,666 & 325,671 & $5,109,056$ & $9,644,864$ \\
\hline $\begin{array}{l}\text { Inhabitants per sq } \\
\mathrm{km} \text { land area }\end{array}$ & 130.5 & 34.6 & 0.1 & 17.9 & 18.5 & 3.6 & 16.9 & 23.7 \\
\hline
\end{tabular}

Source: Nordic Statistical Yearbook 2014, Nordic Council of Ministers, Copenhagen 2014.

${ }^{3}$ For more information about the Nordic region see http://www.norden.org/en/fakta-om-norden-1 
In Appendix 1, there are examples of relevant literature for a Nordic Assessment of Biodiversity and Ecosystem Services. One example is the recent Nordic TEEB (The Economics of Ecosystems and Biodiversity) (Kettunen et al., 2012), which aimed to bring together existing information on the socio-economic role, significance of biodiversity and ecosystem services for the Nordic countries (i.e. Denmark, Finland, Iceland, Norway and Sweden). Regarding some of the socioeconomic value of Nordic nature, see Box 1. Based on available existing information, the study identified the range of ecosystem services maintained by healthy, functioning ecosystems and the present status, trends and socio-economic importance of these services. The study also explored key opportunities and priorities for future policy action, which highlighted the importance of integrating the true value of nature into decision-making processes, and also included possible areas for Nordic cooperation. A range of illustrative case examples were identified and documented (Kettunen et al., 2012).

The study explains that the Nordic countries belong to the Palearctic region with five biogeographical zones present in the area: arctic (Norway, Iceland, Greenland), alpine (Finland, Sweden, Norway), boreal (Finland, Sweden, Norway), atlantic (Norway, Denmark) and continentalnemoral (Sweden, Denmark), and that a boreo-nemoral zone (or hemiboreal vegetation zone) marks the transition between the temperate deciduous forests of the nemoral zone and the coniferous forests of the boreal zone (Kettunen et al., 2012).

The study also indicates that the nature of land cover in the Nordic countries varies from broad-leaved forests in the south of the region, to Arctic tundra in the north, and from boreal forests adapted to continental climate in the east, to the high slopes of the fjords in the west characterised by high annual precipitation. According to the study, Greenland is dominated by glaciers but has supporting ecosystems such as tundra and marine ecosystems with diverse fauna and flora. In Finland and Sweden, forests cover $57 \%$ and $54 \%$ of the surface area, respectively ( $28 \%$ and $46 \%$ of coniferous forests, and $27 \%$ and $4 \%$ of mixed forests), whereas in Denmark forest cover is only $9 \%$, and in Norway forests cover $32 \%$ of the land $(18 \%$ coniferous and $13 \%$ broad-leaved forests). Iceland is dominated by moors and heathlands (35\% of the land area), which also account for $14 \%$ of land cover in Norway. Peat bogs are relatively common, covering around 6-7\% of all Nordic countries, except Denmark. Bare rocks cover $23 \%$ of Iceland, and 7\% of Norway (Kettunen et al., 2012).

The study indicated that agriculture in Nordic countries is subject to climatic constraints, since winter is not suitable for farming and summer is quite short. It also emphasised that there are great differences between 
Nordic countries. For instance, in Denmark over $65 \%$ of the land area is devoted to agriculture; mainly with large farms, on average 60 hectares (ha), and with intensive farming. Iceland, in comparison, only has $1 \%$ of its area cultivated, with most of that being grassland. Sweden and Finland perhaps represent the average, with $5-7 \%$ of their land area covered by agricultural land (average farm size 37 ha). In Norway, agriculture accounts for $2 \%$ of land cover (the average Norwegian farm is only 20 ha). According to the report livestock production is most common in Norway and Iceland, almost all farms in Iceland having livestock (cattle or sheep). Furthermore, in Norway, $60 \%$ of farmers specialise in animal husbandry (with $40 \%$ of those specialising in dairy). (Kettunen et al., 2012). ${ }^{4}$ Regarding the status of biodiversity see Table 2 .

Table 2: Status of biodiversity in the Nordic countries. Source: Nordic TEEB, 2012 (That used EEA SEBI (Streamlining European 2010 Biodiversity Indicators)

\begin{tabular}{lrrrrrr} 
& Denmark & Finland & Greenland & Iceland & Norway & Sweden \\
Number of known species & 30,000 & 45,000 & 9,400 & 9,300 & 40,000 & 50,000 \\
Number of assessed species & 6,442 & 21,400 & 115 & 1,519 & 18,500 & 20,800 \\
Red-listed species (CR, EN, VU)" & 1,471 & 2,247 & 36 & 234 & 3,886 & 3,052 \\
\hline
\end{tabular}

Note: ' Data has been updated based on Rassi et al. 2010.

" Critically endangered (CR), Endangered (EN) and Vulnerable (VU).) It should be noted that according to the Greenland Red List it should be 21 species, but if Near Threatened (NT) are included it would be 36 .

Source: Kettunen et al., 2012.

On the CBD website under "Country profiles", 5 information is available on "Biodiversity Facts and Measures to Enhance Implementation of the Convention." It covers status and trends in biodiversity, including benefits from biodiversity and ecosystem services; main pressures and drivers of change to biodiversity (direct and indirect); implementation of the National Biodiversity Strategies and Action Plans (NBSAPs); actions taken to achieve the 2020 Aichi Biodiversity Targets; and mechanisms for monitoring and reviewing implementation. An earlier project financed by the Nordic Council of Ministers, "Nordic Nature - trends towards 2010"5 a Nordic communication project on biological diversity, should also be

\footnotetext{
${ }^{4}$ Some of the data from the Nordic TEEB are not the exact number as in the Nordic statistical yearbook, but similar, differences might be due to source and difference in year measured.

${ }^{5} \mathrm{http}: / /$ www.syke.fi/en-us/Research_Development/Research_and_development_projects/Projects/ Nordic_nature_trends_towards_2010
} 
mentioned. The project published fact sheets on status, trends in biological diversity, and threats to it, as well as success stories and best practices in protecting biodiversity.

The Nordic EU Member States' information can also be found in the "Biodiversity Information System for Europe (BISE)"6 with data and information on biodiversity supporting the implementation of the EU strategy and the Aichi targets in Europe, and EU biodiversity factsheets ${ }^{7}$ for EU Member States.

\section{Box 1. Examples of value of Nordic nature in Nordic TEEB}

Examples of insights regarding the socioeconomic value of Nordic nature according to the Nordic TEEB's Summary for Policy Makers (Kettunen et al., 2013):

- Fishing in Nordic countries is important both as an industry and as a hobby, creating a high demand for sustainable management of fisheries resources. In Finland, Sweden and Norway, 44\%, 30\% and 50\% of the population, respectively, reported having engaged in some kind of fishing activity in the past year.

- The socioeconomic importance of hunting in Nordic countries comes from a combination of revenue providing activity, household subsistence value, as well as cultural and recreational significance. Around one million Nordic people go hunting every year - equivalent to almost $5 \%$ of the total Nordic population.

- Recreational activities in nature are extremely popular in Nordic countries. A typical adult Finn undertakes some kind of outdoor activity on average three times a week. In Sweden, 36-56\% of people reportedly use forests for walking at least twenty times a year. In Norway, hiking in forests or mountains is practised more than twice a month by almost half of the population (i.e. around 2.4 million people). Finally, in Denmark approximately $70 \%$ of the population visit green areas several times a week. Furthermore, outdoor life can have significant impacts on regional and national economies.

- The estimated economic value of berries picked for markets ranges between EUR 500,000/year in Norway, to over EUR 30 million/year in Sweden (in 2005). In addition to berries traded at organised markets, a significant amount of berries are sold via direct markets.

${ }^{6} \mathrm{http}: / /$ biodiversity.europa.eu/info

7 http://biodiversity.europa.eu/countries/eu_country_profiles 
- In Finland, the estimated value of carbon sequestration from Finnish forest trees is EUR 1,876 million, and the value of the mineral soil carbon stock is thought to be EUR 136 million. In Sweden, the annual carbon sequestering value of forest cover is estimated to be between EUR $\sim 3.3$ and $\sim 5.2$ billion based on the estimated consumption value of EUR $\sim 1.2-\sim 2$ billion and investment value of EUR $\sim 2-\sim 3.2$ billion.

- Altogether 134 wild Nordic plant species have been identified with medicinal or aromatic properties.

\section{The Arctic}

(Section on the Arctic produced by Tom Barry, Executive Secretary, Conservation of Arctic Flora and Fauna (CAFF) Arctic Council Working Group)

In 2013, the Conservation of Arctic Flora and Fauna (CAFF), the biodiversity working group of the Arctic Council, released the Arctic Biodiversity Assessment (ABA) (CAFF, ABA 2013a). This report contained the best available science informed by traditional ecological knowledge on the status and trends of Arctic biodiversity and accompanying policy recommendations (CAFF, ABA 2013b) for biodiversity conservation (Figure 1: ABA boundary). The assessment explored potentially dramatic consequences of climate change and other factors that could adversely affect species and their habitats in the Arctic, providing critical information to policy makers. The ABA found that large tracts of the Arctic remain relatively undisturbed, providing a unique opportunity for proactive action to minimise or even prevent future problems that would be costly, or impossible, to reverse.

The Arctic Council ministers agreed to implement the 17 recommendations articulated in the Arctic Biodiversity Assessment, Report for Policy Makers (CAFF, ABA 2013b). At the April 2015 Arctic Council Ministerial meeting, the Arctic states were presented with an 8-year implementation plan, Actions for Biodiversity 2013-2021 (CAFF, 2015a). This action plan was informed by discussions with Arctic Council countries, indigenous organisations, observer organisations, and countries. Actions for Biodiversity 2013-2021 will act as the key guide to Arctic Council biodiversity conservation in the coming years.

Although actions for implementing ABA recommendations are aimed primarily at the Arctic Council, member states and permanent participants, the success in conserving Arctic biodiversity depends on actions by non-Arctic states, regional and local authorities, industry, and all who live, 
work, and travel in the Arctic. ABA recommendations, therefore, also provide a guide for biodiversity conservation action for authorities and organisations beyond the Arctic Council.

One of the three themes of the ABA focused on the importance of mainstreaming biodiversity by making it integral to other policy fields. For instance, by ensuring biodiversity objectives are considered in development standards, plans and operations. The ABA recommended that the range of services provided by Arctic biodiversity should be evaluated in order to determine the costs associated with biodiversity loss, the value of effective conservation, as well as to assess change and support improved decision making. As a first step towards mainstreaming Arctic biodiversity and ecosystem services into policy and decision-making processes, the Arctic Economics of Ecosystems and Biodiversity (TEEB) Scoping Study (CAFF, 2015b) ${ }^{8}$ was delivered to the 2015 Arctic Council Ministerial. This scoping study made more people aware of how Arctic natural values might be recognised, and how they could be used to improve policies and decision making linked to key issues facing the Arctic.

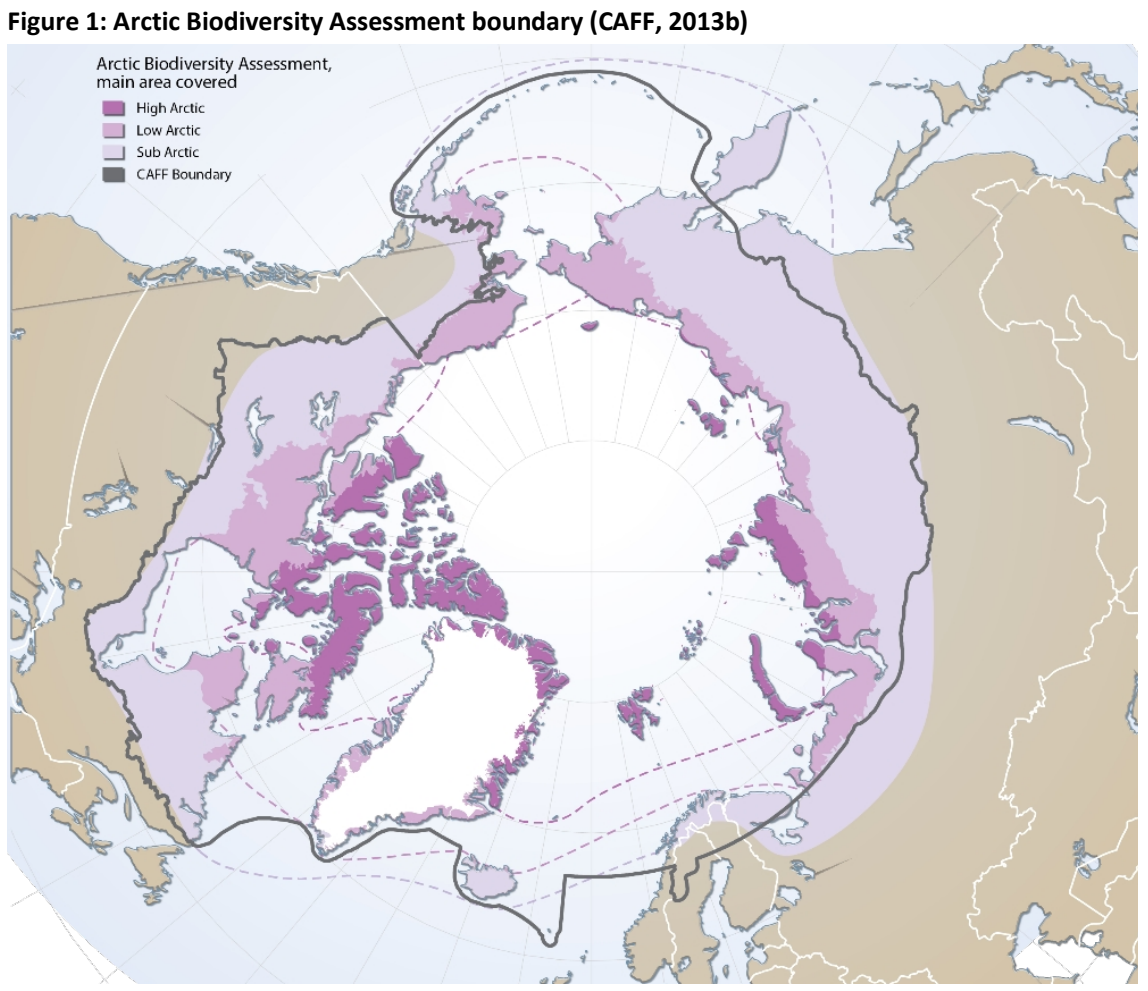

8 Developed in partnership with the TEEB office, UNEP, WWF and GRID Arendal. 
Going further into the report, we can see how scientific findings led to policy recommendations and subsequently to informed policy actions. For example, ABA key finding no. 3 states that many Arctic migratory species are threatened by overharvest and habitat alteration outside the Arctic, especially birds along the East Asian flyway (CAFF 2013b). An additional key finding states that challenges facing Arctic biodiversity are interconnected, requiring comprehensive solutions and international cooperation (CAFF 2013b). These findings informed ABA recommendation no. 8: "Reduce stressors on migratory species range-wide, including habitat degradation and overharvesting on wintering and staging areas and along flyways and other migration routes." The Actions for Biodiversity 2013-2021 response was the creation of the Arctic Migratory Birds Initiative (AMBI). 



\section{SECTION I. Introductory Study including Scoping - Process, Method and Discussion}

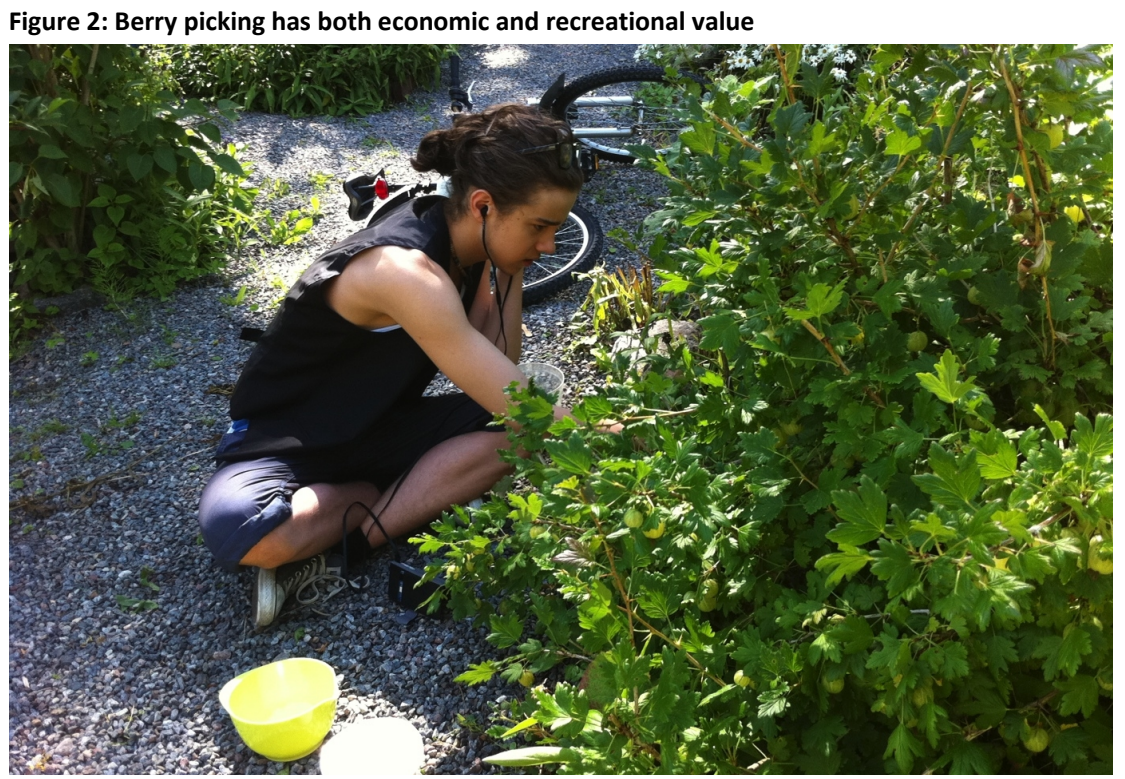

Note: Berry picking is a source of revenue in the Nordic countries, and for many Nordic citizens an appreciated recreational activity. Picture from allotment garden in a suburban area of Stockholm. Allotment gardens also contribute ecosystem services such as pollination.

Source: Photo: Maria Schultz.

\subsection{Background, Process and Method}

According to the Global Biodiversity Outlook 3 (Convention on Biological Diversity, CBD, 2010) species that have been assessed for extinction risk are, on average, moving closer to extinction. Nearly a quarter of plant species are estimated to be threatened with extinction. Crop and livestock 
genetic diversity continues to decline in agricultural systems, as well as traditional knowledge, innovations and practices associated with biodiversity and ecosystem services. (CBD, 2010; CBD, 2014)

Policy and decision makers need to be aware of the importance of biodiversity for human well-being. The educational task of explaining the links between healthy ecosystems and opportunities they provide is crucial in these times of unprecedented global social, environmental and climatic change. To contribute towards meeting these needs, the "Intergovernmental Science-Policy Platform on Biodiversity and Ecosystem Services" (IPBES) was established 2012. For further background regarding IPBES see above "Background and introduction" section of this document.

During a Nordic meeting on IPBES in Stockholm 2014, it was suggested that the possibility of a Nordic Assessment of Biodiversity and Ecosystem Services based on IPBES methods and procedures should be explored. It was decided that the best way to prepare for such an assessment would be through a thorough scoping study. The Swedish Environmental Protection Agency (SEPA) sent a proposal to the Terrestrial Ecosystem Group of the Nordic Council of Ministers, which approved DKK 450,000 for the "Scoping Study Nordic Assessment to feed into IPBES". Project goals for the study were: to lay the foundation for a Nordic sub-regional assessment that can feed into the IPBES process; to assist Nordic countries in reporting requirements and preparation for IPBES and other international forums; to disseminate IPBES methods within the Nordic countries; to engage Nordic scientists and other knowledge holders in IPBES processes; to establish a successful Nordic working group for carrying out a sub-regional assessment and other IPBES-related cooperation; and to demonstrate successful cooperation between countries on these issues. The scoping study was to deliver a project plan for the full Nordic Assessment. Expected outcomes, in short, were to: develop the methodology (to make a Nordic instrumental model for a IPBES-like assessment); identify actors that can contribute to the full assessment; identify data and knowledge sources and gaps; find key questions for the full Nordic Assessment; and be able to use the final product for proposals for a Full Nordic Assessment, including a budget.

The project group, selected by Nordic countries government agencies, met about twice a month through telephone conferences in 2015, and in one dialogue meeting, which also included actors other than the project group, including scientists and representatives from indigenous and local knowledge holders. Consultations took place through two questionnaires (a longer questionnaire for face to face meetings, and a shorter questionnaire that was sent out to actors in the Nordic countries). Through this 
process the project group tried to find a focus for the most policy relevant questions and issues in a Nordic context. The questionnaire was sent out to around 200 Nordic recipients, but only 19 responded. They indicated a need for further clarification of terminology, and most respondents advocated a transdisciplinary approach when conducting the assessment in order to capture and reflect as much complexity as possible, such as historical, political and legal perspectives, natural and social sciences, knowledge of trade, human psychology and welfare, as well as multiple knowledge systems. The longer questionnaire was used at the Nordic meeting with the project group and other actors, attended by 18 participants, and at country meetings and consultations such as a meeting with the Swedish Scientific Council on Biodiversity and Ecosystem Services (Vetenskapliga rådet för biologisk mångfald och ekosystemtjänster). The discussions are incorporated systematically into Section II of this document. For further information and results, see the full working document available through SEPA.

A study related to indigenous and local knowledge (ILK) was performed within this project, and was financed by the Swedish Environmental Protection Agency. It was assigned to the NAPTEK programme (Swedish National Programme on Local and Traditional Knowledge related to Conservation and Sustainable Use of Biodiversity) at the Swedish Biodiversity Centre. In order to fully consider the perspectives of the ILK actors and the particular context of the IPBES in a Nordic setting, the assignment dealt with four connected activities: 1) a Nordic dialogue workshop for ILK actors; 2) an ILK questionnaire focusing on how to achieve full and effective ILK participation in practice; 3) a project piloting local ILK workshops implemented by the Snowchange Cooperative (an ILK non-governmental organisation (NGO) in Finland and; 4) an interview and literature study on citizen science in the Nordic countries and its potential contribution to a full Nordic Assessment of Biodiversity and Ecosystem Services. For a summary of the study, see Annex 1. For terms of reference and results of the conducted dialogue under the assignment, as well as the questionnaire related to the NAPTEK study, see the full working document of this study and the full report from the ILK project: "Report from the project: Indigenous and Local Knowledge in a Scoping Study for a Nordic IPBES Assessment" (Tunón et al., 2015). Results from all the above activities are incorporated into this Introductory Study and Project Plan, Section II. 
Figure 3: A Nordic Indigenous and Local Knowledge (ILK) dialogue workshop was held as part of the ILK scoping study within the Nordic study

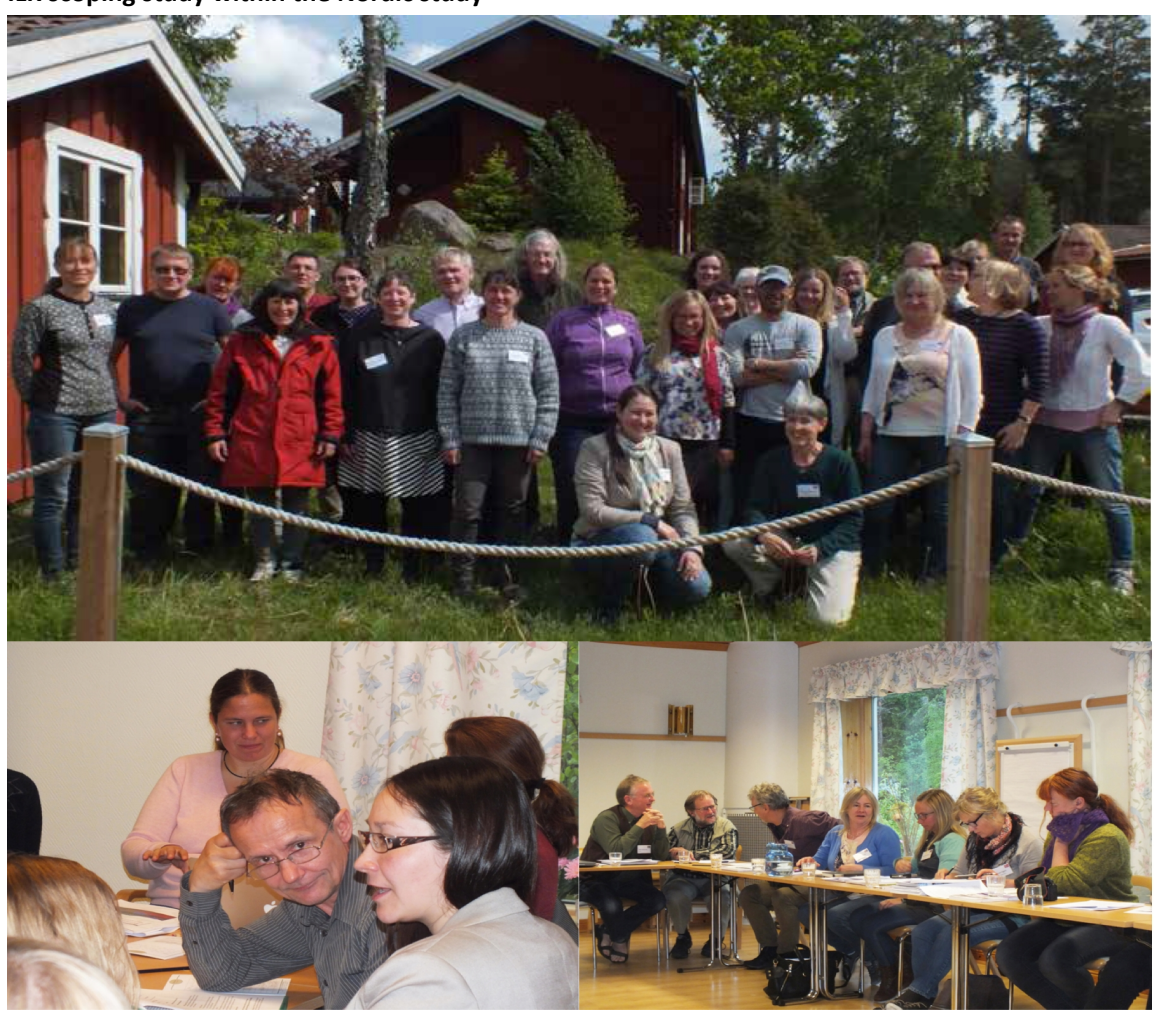

Note: The 30 participants were indigenous peoples - Saami people and Inuit - as well as representatives of other local knowledge systems in the Nordic countries: Denmark, Finland, Iceland, Norway, and Sweden and also the autonomous areas of the Faroe Islands, Greenland, and Åland. The workshop demonstrated that ILK is vital for assessment and for sustainable use of biodiversity and ecosystems.

Source: Photo: Staff at Odalgården.

The process of this study added Nordic specific aspects to the agreed IPBES documents. The outline for this introductory study and project plan is based on the following IPBES related documents:

- Generic scoping report for the regional and sub-regional assessments of biodiversity and ecosystem services, IPBES/3/18, Annex III.

- Scoping for a regional assessment on biodiversity and ecosystem services for Europe and Central Asia, IPBES/3/18, Annex VII.

- Other guidance under IPBES, such as the guide regarding diverse conceptualisation of multiple values of nature and its benefits; and 
policy support tools; methodologies for scenario analysis; and rules of procedures for IPBES.

The project leader and each country node gathered data related to literature, data sources, strategic partners and potential funding sources, and documented this in an Excel meta-database, of which a shorter version is presented here as Appendices I-V to Section II.

As mentioned previously, IPBES developed from the Millennium Ecosystem Assessment and International Mechanism of Scientific Expertise on Biodiversity IMoSEB. It should be said that a number of linked socialecological system assessments have been developed over the years. These have influenced the development of IPBES general scoping documents, as well as this scoping of the Nordic Assessment of Biodiversity and Ecosystem Services. In Annex 2, "International - Examples of relevant processes, literature, and data sources" some of the main assessments, tools and indicators are included for an overview.

\subsubsection{Project Group for the Nordic Introductory study including scoping}

A project group was selected by government agencies in the Nordic countries: Denmark (DK), Finland (FI), Iceland (IS), Norway (NO), Sweden (SE), Greenland (GL) and Åland (AX). The Faroe Islands (FO) were invited but were unable to participate. Greenland's (GL) representative monitored the process as a reviewer. The representatives are presented below:

- Denmark (DK): Eva Roth, Senior Lecturer, cand.polit./Associate Professor, Department of Environmental and Business Economics, University of Southern Denmark; and Mette Gervin Damsgaard, Naturstyrelsen/Ministry of Environment Denmark.

- As reviewer only - Greenland (GL): Inge Thaulow, Special Advisor on international environmental affairs, Government of Greenland.

- Finland (FI): Petteri Vihervaara, Adjunct Professor, PhD, Senior Research Scientist, Research Programme Manager (Ecosystem Services), Finnish Environment Institute (SYKE), Natural Environment Centre.

- Åland ( $A X)$ : Inkeri Ahonen and Maija Häggblom, Nature Conservation Officers, Department of Social Affairs, Health and Environment, Government of Åland. 
- Iceland (IS): Sigurdur Thrainsson, Head of Division, Ministry for the Environment and Natural Resources, Department of Land and Natural Heritage.

- Norway (NO): Nina Vik, Senior Adviser, Global Biodiversity Section, Norwegian Environment Agency.

- Sweden (SE): Cecilia Lindblad, Senior Adviser, Research and Assessment Department, Swedish Environmental Protection Agency.

- Project leader: Maria Schultz, Swedish Environmental Protection Agency, (Stockholm Resilience Centre).

\subsection{Result of Introductory Study including Scoping}

The project goals for the study are described in the project proposal to the Nordic Council of Ministers. These project goals have been more or less reached. The study has laid the foundation for a Nordic sub-regional assessment that can feed into the IPBES process, although the focus needs to be discussed further. Results have been documented in Section II, which includes findings from the introductory study and suggestions for a project plan for a full Nordic Assessment. Regarding assistance to Nordic countries in reporting requirements for IPBES and other international forums, this has been achieved to some extent, but depends on whether a full Nordic Assessment will be conducted. The questionnaires, meetings and discussions with knowledge holders at the Nordic level, among university staff, practitioners and policy makers, have contributed to disseminating IPBES methods within the Nordic countries. There has been some level of success in informing and engaging Nordic scientists and other knowledge holders about IPBES, and in establishing Nordic collaboration. If a full Nordic Assessment is performed, this will be strengthened.

The more detailed expected outcomes have been fulfilled regarding: developing the methodology (to make a Nordic instrumental model IPBESlike assessment); identifying actors that can contribute to the full assessment; data, knowledge sources and gaps; finding key questions for the full Nordic Assessment; and being able to use the final product for proposals for a full Nordic Assessment, including a budget for the full assessment. 


\subsection{Discussion - Introductory Study including Scoping}

The scoping study was a "test case" to analyse whether these kinds of assessments are feasible, constructive and provide added value to other national processes. Some of the main challenges are discussed here.

\subsubsection{Scope and Focus}

In this scoping process, we have not fully managed to find the focus for the potential Nordic Assessment of Biodiversity and Ecosystem Services. Possible delimitation has been discussed in terms of biomes or ecosystems, and in terms of importance of mainstreaming, such as valuation of ecosystem services, but also common cultural and behavioural aspects, such as nature outdoor activities. A common denominator for judging what is most important in a Nordic context has been common natural resources, common resource use, common cultural and behaviour aspects as well as common governance aspects. A question that has come up during the process regarding the focus of the assessment has been whether the focus should be on biodiversity in itself, including intrinsic values, or on ecosystem services and the utility approach. It was argued that a very anthropocentric view, valuing biodiversity and ecosystem services only provided they provide economic benefits and "well-being," would lead to a utility trap, which might be one of the root causes of the loss of biodiversity. In the final project plan, we now try to grasp both that biodiversity has relevance to the delivery of ecosystem services and that the values related to biodiversity are also intrinsic in nature.

Other issues discussed have considered what baseline to use, and which scenario and time perspective to use, i.e. forest values are not easily covered over just a few decades. The suggested time-frames under IPBES seem to be based on policy considerations.

Geographic boundaries were another issue for consideration, since biodiversity does not respect human governance borders (neither in the ocean nor on land), and therefore it might be relevant for the Nordic Assessment to use biogeographical regions and/or watersheds. The Nordic region also includes strong climatic gradients translating into distinct regions and ecosystems - the project plan recognises examples of boreal and arctic landscapes.

It is important to keep in mind that the Nordic countries, although similar, are highly diverse. 
Denmark is characterised by $65 \%$ agriculture land cover, especially by large farms (average farm size of $60 \mathrm{ha}$ ) and intensive agriculture. Conversely in Iceland, only $1 \%$ of the area is cultivated and most of that is grassland. In Finland and Sweden forests take up 57\% and 54\% of the surface area, respectively. Denmark, in comparison, has only $9 \%$ forest cover, while in Norway, forests cover $32 \%$ of the land (Kettunen, 2012).

Finland and Sweden together represent $12.8 \%$ of the world's production of wood pulp, a major export item for these two countries. In Iceland, the Faroe Islands and Greenland, fisheries are the dominant industry, both with respect to production and exports. In the Faroe Islands, almost $89 \%$ of export value stems from fishing and in Greenland 63\% (according to Statistics of Greenland it is approximately 90\%, Grønlands Statistik, 2013). ${ }^{9}$ In Iceland, export value is close to $39 \%$ and, about $3-4 \%$ and $6-7 \%$ in Denmark and Norway respectively (Nordic Council of Ministers, 2014).

\subsubsection{Terminology}

Another issue raised during the scoping study was terminology and the importance of language, for example related to the vocabulary of nature's benefits, ecosystem services and ecosystem functions; and human wellbeing vis-a-vis the terminology "good quality of life" etc. Questions raised concerned what we consider to be "well-being"; a new car or a walk in a natural forest? Translation into native languages also proved to be difficult. To understand what "ecosystem services" are, it was considered that there is first a need to know what an ecosystem is, and what the relationship with biodiversity components is. The terminology "ecosystem services" was considered by some to represent too much of a utilitarian view of the relationship between humans and nature.

An extensive glossary has been developed, see Annex 9, in an attempt to tackle some terminology-related issues. It is important to emphasise that language depends on values, and this is something to discuss further in the (potential) full assessment. Words need to be discussed and defined in the specific context of use and preferably be based on the perception of the citizens in the region, depending on the context of the actual place of use and how they are understood among different actors.

${ }^{9}$ http://www.stat.gl/dialog/main.asp?lang=da\&version=201301\&sc=SA\&co lcode=p 


\subsubsection{Citizen Science and Indigenous and Local Knowledge}

This study has started to explore how citizen science and ILK can contribute together with science in a possible Nordic Assessment, building on perspectives developed in the report on ILK related to the Nordic Assessment by NAPTEK, see Annex 1 . The discussion needs to continue. In particular, how in practice knowledge systems together can provide an enriched picture, and definitions of citizen science and indigenous and local knowledge. Advancements are made under the IPBES task force on ILK and research such as the Multiple Evidence Base Approach (Tengö et al., 2014).

\subsubsection{Data}

The scoping called for building some kind of Nordic biodiversity and ecosystem services meta-database, identifying core knowledge resources across the region. Some data has been gathered in the scoping process. The consideration for building a specific Nordic database, including its maintenance, has to be considered early in the assessment process. Since datasets are infinite, ranging from species lists of birds at single sites, to national forest inventories and historical documents of land use; the critical thing is how to decide and define what constitutes a relevant "key" dataset. What is actually useable for an assessment to be finalised within a few years? This has to be considered throughout the potential assessment phase.

\subsubsection{Outreach}

During the introductory and scoping process, a need has been expressed for finding innovative ways to present data and to increase the capacity of decision makers to grasp the importance of biodiversity and ecosystem services - such as through interactive websites and maps, deliberative workshops, etc. The target group regarding the use of the assessment has been deemed to be broad. Regarding the government level, it has been stressed that not just Ministries of Environment should be addressed, but also Finance and Foreign Affairs, and sector authorities such as for Agriculture, Forestry and Marine issues. 


\subsubsection{Budget and funding}

Funding is a key challenge regarding performance of the Nordic Assessment, similar to many IPBES Assessments. The real challenge in the Nordic countries is to find enough people able to devote sufficient time - i.e. a large number of persons and organisations are expected to work with funding from self-found sources. This means that the project needs to offer very strong incentives for people to participate, i.e. needs that are compatible with those of scientists or other knowledge holders. The need for full cost recovery for participation and contributions from scientists and indigenous and local knowledge holders has been stressed. How to deal with this is not clear, and it is not covered in the budget. Funds have been applied for from Nordic Council of Minsters for the full assessment. An additional solution is to find research teams, and themes for funding proposals, to contribute to the assessment in a structured manner. Examples of potential funding sources are listed in Annex 6. The governments in the Nordic countries will also be approached on potential funding.

\subsubsection{Organisation}

Nordic countries do not have an IPBES organisation, like a governance body such as an IPBES plenary, but this study has suggested a structure adapted to Nordic options. The project group was not selected through a nomination process, but by government authorities. The suggested organisation of the potential Nordic assessment could, for example, have an entity similar to the Multidisciplinary Expert Panel in the form of an Expert Committee that has to be selected through a nomination process. See further information under Organisational Structure and Rules of Procedure in Section II.

\section{Risks}

The risks related to funding and data have been discussed during the process and have already been mentioned. Another risk is that the assessment might be a source of conflict, since national interests may differ. 


\subsection{Conclusions - Introductory Study including Scoping}

This study has shown a path towards establishing a Nordic Assessment of Biodiversity and Ecosystem Services based on IPBES methods and procedures. However, there are still three major questions to answer:

- The introductory study has not specified the focus for a Nordic Assessment of Biodiversity and Ecosystem Services. The choice is between an overall and general assessment in line with the generic scoping documents for the regional and sub-regional assessments of biodiversity and ecosystem services under IPBES; or focusing on a topic such as the link between biodiversity, ecosystems, and ecosystem services they provide, and "valuation of ecosystem services" for mainstreaming and sustainable use; or on a specific ecosystem such as marine, coastal and wetland ecosystems or forests. This will have to be decided at the beginning of the assessment.

- The process for deciding on the scope has to be defined. A pragmatic way would be to create a board representing the Nordic government authorities, and explore the possibility of a start-up workshop under the auspices of the Nordic Council of Ministers.

- Securing funding for broad participation in the work carried out in the Nordic Assessment is a challenge.

Furthermore, the feasibility of a Nordic Assessment is dependent on buyin and commitment from the Nordic countries' governments, with respect to both funding and use of the assessment.

There are still challenges to be solved for the establishment of a Nordic Assessment of Biodiversity and Ecosystem Services based on IPBES methods and procedures, but it may, if established, contribute to meeting the urgent need to halt biodiversity loss, and to increasing the understanding of biodiversity, ecosystems and the links to human well-being. 



\section{Section II. Introductory Study and Project Plan - including chapter outline}

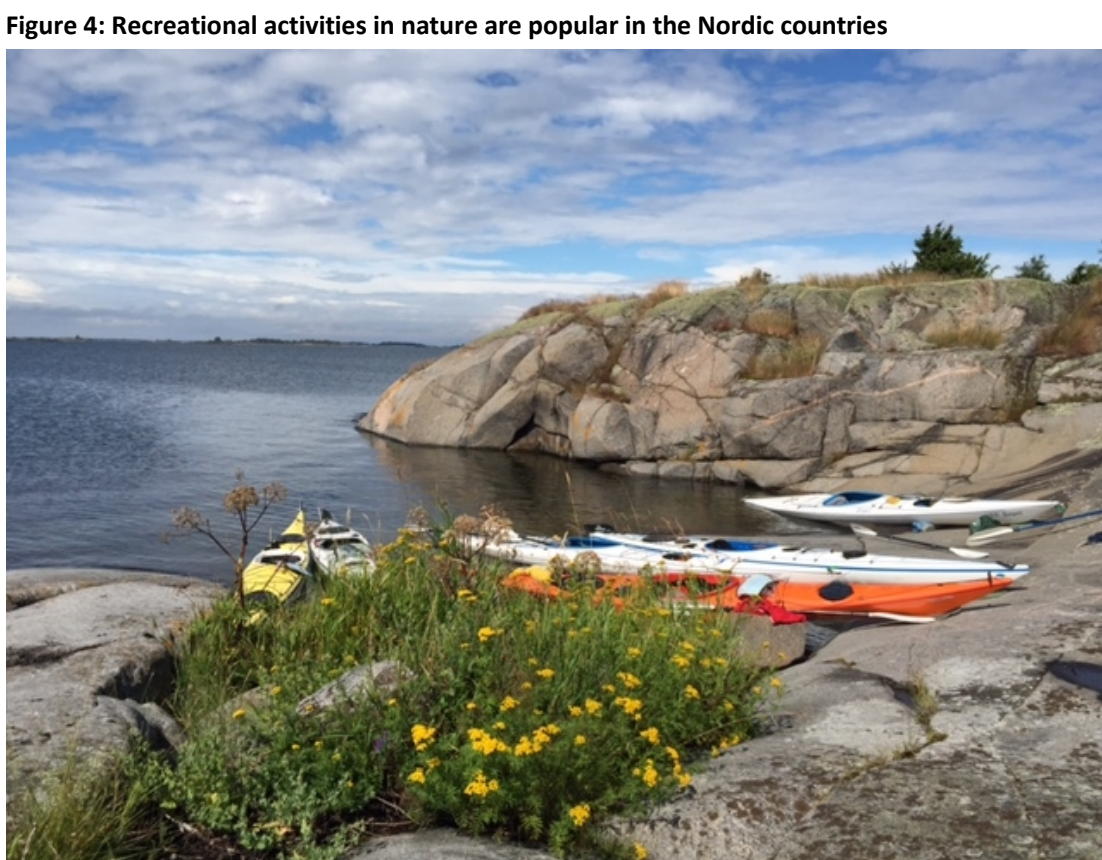

Note: Kayaking in Saint Anna Archipelago, in Sweden, that comprises more than six thousand islands and you are free to paddle and camp wherever you like except on some islands in times of bird reserve restrictions.

Source: Photo: Maria Schultz.

\subsection{Introduction}

The findings and project plan for a Nordic Assessment, presented in this section, have been developed through literature studies, and in consultations with scientific and other knowledge holder experts, policymakers and practitioners through meetings, seminars and questionnaires. For further information, see Background and Introduction and Section I. 


\subsection{Nordic Assessment - Scope, geographic boundary, rationale, utility and assumptions}

\subsubsection{A. Scope}

The Nordic Assessment should follow the IPBES conceptual framework that includes six interlinked elements constituting a social-ecological system that operates at various scales in time and space: nature; nature's benefits to people; anthropogenic assets; institutions and governance systems and other indirect drivers of change; direct drivers of change; and good quality of life. The framework (Díaz et al., 2015) ${ }^{10}$ is graphically depicted in Figure 5.

The objectives of the Nordic Assessment processes should be to strengthen the science-policy interface for biodiversity and ecosystem services as well as the conservation and sustainable use of biodiversity, long-term human well-being and sustainable development at a Nordic level, and to feed results into the IPBES assessment of Europe and Central Asia (ECA).

The overall scope of the Nordic Assessment should be to assess issues of relevance in a Nordic context, for instance common natural resource use, such as marine areas, mountain areas, agriculture and land use activities that affect cross-border habitats of species, or ecosystem services; common drivers in Nordic countries, such as land use change that might affect habitats, biodiversity and ecosystems in the whole region; common cultural or behavioural aspects, such as nature outdoor activities; common similarities regarding responses, such as governance aspects in the Nordic region, e.g. fiscal issues; how governance systems in one country might affect the whole region; or governance structures that need to be better linked due to the governance of the commons in the Nordic region.

\footnotetext{
${ }^{10}$ Report of the second session of the Plenary of the Intergovernmental Science-Policy Platform on Biodiversity and Ecosystem Services, IPBES/2/17, 9 January 2014.
} 
Figure 5: Analytical conceptual framework

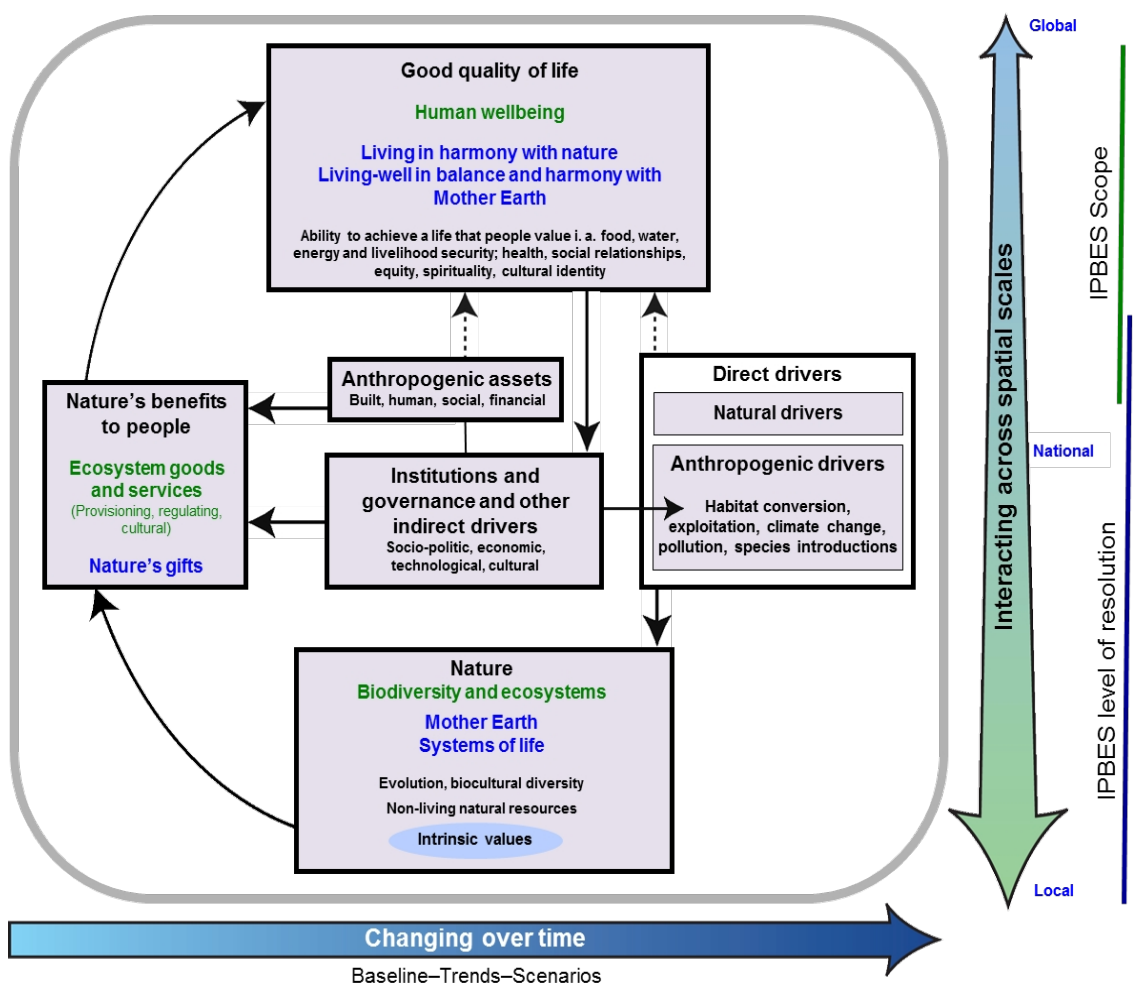

Note: Figure 5 demonstrates the main elements and relationships for conservation and sustainable use of bio-diversity and ecosystem services, human well being and sustainable development. Similar conceptualizations in other knowledge systems include "living in harmony with nature" and "Mother Earth", among others. In the main panel, delimited in grey, "nature", "nature's benefits to people" and "good quality of life" (indicated as black headings) are inclusive of all these world views; text in green denotes the concepts of science; and text in blue denotes those of other knowledge systems. Solid arrows in the main panel denote influence between elements; the dotted arrows denote links that are acknowledged as important, but are not the main focus of the Platform. The thick coloured arrows below and to the right of the central panel indicate different scales of time and space, respectively. Even if the figure cannot be changed, the Nordic Assessment should address more processes and dependencies than expressed with the arrows in the conceptual framework of IPBES, taking into account that ecosystem services are often produced in the interlinked social-ecological systems.

Source: Díaz et al., 2015. 
Box 2. Options for Scope and Focus of the Nordic Assessment of Biodiversity and Ecosystem Services based on IPBES methods and procedures

A challenge during the work with the scoping of the Nordic Assessment has been to narrow the scope and focus of the assessment to an accomplishable level. The point of departure is based on what is considered to be of most importance in a Nordic context, such as aspects related to common natural resources, common resource use, common cultural and behaviour aspects and common governance aspects.

The assessment may focus on a number of essential nature types, ecosystems, or ecosystem services, or drivers. Examples discussed have been tourism and recreation; forestry, including industrial to mountain forests (fjällnära skog); various agricultural activities; reindeer husbandry; aquaculture; fishery; marine areas and coastal zones; urban areas and urban sprawl. Also, marshlands (fens) and natural pastures of the fennoscandic type might be among those most important because they depend on the development trend in forestry and agriculture towards larger units and more intensive production.

The Nordic Assessment might find a focus for several sub-assessments, that might correspond to the main specified focus issues. Lead institutions or hubs in the Nordic countries, that could contribute to selected authors, could also contribute in finding financing for these separate parts of the assessment.

The suggested chapter structure should preferably be used for potential sub-assessments, such as:

- Issues that the Nordic countries and regions find most important in terms of mainstreaming, such as valuation of ecosystem services, or common cultural/behavioural aspects, such as outdoor nature activities. And common natural resource use, such as marine areas, and land use activities that also affect cross-border habitats of species, and ultimately ecosystem services. (Chapter 2).

- Biodiversity and the links to delivery of ecosystem services (Chapter 3).

- Common drivers in Nordic countries, such as land use change that might affect habitats, biodiversity and ecosystems in the whole region. Effects of energy production and infrastructure, and invasive alien species might be aspects to include here. (Chapter 4).

- Integrated, and cross-scale analysis, including cross-border effects, using e.g. biogeographically and watersheds as borders. (Chapter 5).

- Common responses such as governance aspects specific for the Nordic region, e.g. related to sustainable use, the fiscal system, and how a governance system in one country might affect the whole region; which links back to the 
first question on common natural resource use. Outreach via innovative interactive maps and tools to aid in decision-making should also be focused on. (Chapter 6).

A clear scope and focus of the Nordic Assessment has not been reached. The Nordic Assessment project has to discuss this issue in more detail right at the beginning of the Nordic Assessment. The process for deciding upon scope also has to be defined. Will it be the Nordic governments, the Nordic Council of Ministers or another entity that has the mandate to do this?

The Nordic Assessment should address the following policy-relevant questions specifically (for further information see section V. Nordic Assessment - Chapter Outline):

- How do biodiversity and ecosystem services contribute (and what are the interdependences among them) to the economy, livelihoods, food security, and human well-being in the Nordic region? How might loss of these affect the economy, livelihoods and well-being in the region? How can loss be avoided? The assessment should focus on these questions, related to the Ecosystem Services Box in the conceptual framework, corresponding to Chapter 2: Ecosystem Services and Human Well-being (Nature's benefits to people and good quality of life).

- What are the status, trends and potential future dynamics of biodiversity and ecosystem services that affect their contribution to the economy, livelihoods and well-being in the region? Which spatial patterns and structures do we see and what are the implications? What temporal dynamics do we see and across what scales? What and where are the potential future losses? What are the linkages between ecological functions and the ecosystem services obtained, and how do they interact in interdependent bundles? The assessment, guided by these questions, should focus on biodiversity and ecological functions and their effect on ecosystem services, corresponding to Chapter 3: Status, trends and future dynamics of biodiversity and ecosystems underpinning nature's benefits to people.

- What are the threats (including macro-economic drivers), trends and pressures driving change in the status and trends of biodiversity and ecosystem services in the Nordic region? What are the effects of production, consumption and economic development 
on biodiversity and ecosystem services? The assessment should analyse direct and indirect drivers, as well as how indirect drivers affect direct drivers. This corresponds to Chapter 4: Direct and indirect drivers of change in the context of different perspectives of human well-being (quality of life).

- What are the various paths towards sustainable development? The questions to be analysed correspond to Chapter 5: Integrated and cross-scale analysis of interactions of nature and human society.

- What are the options for governance, institutional arrangements and private and public decision-making across scales and sectors? What are the actual and potential impacts of different policies and interventions on biodiversity and ecosystem services? What are the legitimacy and effectiveness ${ }^{11}$ of responses? ${ }^{12}$ How can loss of biodiversity and ecosystem services (such as those underpinning ecosystem-based adaptation to climate change and nature-based solutions to sustainable development) be prevented, and their sustainable use or restoration be encouraged through policy and economic instruments, including investments, regulations and management regimes? What sustainable use practices of biological resources are there? How does customary use of biological resources contribute to continuous ecosystem functioning? How can sectoral policies and new policy instruments make use of opportunities arising from the contribution of biodiversity and ecosystem services to human well-being? What are the opportunities for ecological infrastructures and ecological technologies? What other solutions are there? These questions correspond to Chapter 6: Options for governance, institutional arrangements and private and public decision-making across scales and sectors.

- What gaps in knowledge need to be addressed in order to better understand and assess drivers, impacts and responses of biodiversity, ecosystem functions and services at the regional level? What knowledge is underutilised and could contribute additional values if brought into policy decisions? What learning processes and

\footnotetext{
${ }^{11}$ In relation to biodiversity financing including policy and economic instruments, Vatn has suggested that for successful assessment of different biodiversity financing mechanisms we need to consider both "process legitimacy" and "outcome legitimacy". The latter consists of three parts; effectiveness (what is the effect on biodiversity?), efficiency (are we reaching the goal in a cost-effective way?), and equity (effect on distribution).Vatn et al., Can markets protect biodiversity? An evaluation of different financial mechanisms. Norad Report 19/2011 Discussion. Also published as Noragric Report No. 60 (June 2011).

12 Including the Strategic Plan for Biodiversity 2011-2020 and its Aichi Biodiversity Targets and the national biodiversity strategies and action plans developed under the Convention on Biological Diversity.
} 
teaching are needed to continuously learn about biodiversity and ecosystem services, and adapt to governance in a collaborative learning process between actors? It is important to use an analytical approach - to continuously test methods and unintentional biases.

The scope described above is very wide, as it encompasses biodiversity in its entirety. For each of the questions, the Nordic Assessment needs to concentrate on clearly specified subject matters. Narrowing the scope is problematic, and the process must be transparent and involve a wide selection of stakeholders. See more in Box 2: Options for Scope and Focus of the Nordic Assessment.

National environmental targets, and other commitments such as the CBD Aichi targets (see Annex 8), and the Sustainable Development Goals, should guide the selection of biodiversity components and ecosystem services included in the assessment. The Assessment needs to focus on the added value of a Nordic Assessment, compared to country assessments. The regulatory and subsidiary systems show both similarities and differences between the different countries. The Nordic countries also share a common history and future, as well as common ecosystem services that need to be co-managed. But it is important to keep in mind that although there are many similarities across Nordic countries, they are highly diverse with respect to natural resources and their uses.

From the perspective of indigenous peoples and local communities, there are similarities and differences in customary uses of both similar and different ecosystems, which contributes to a varied picture.

\section{Box 3. MAES and ESMERALDA}

The Directorate-General for Environment is the European Commission department responsible for EU policy on the environment. DG Environment has set up a Working Group for Mapping and Assessment of Eco-systems and their Services (MAES) to specifically implement EU Biodiversity Strategy to 2020 Target 2, Action 5, that foresees that: "Member States, with the assistance of the Commission, will map and assess the state of ecosystems and their services in their national territory by 2014 , assess the economic value of such services, and promote the integration of these values into accounting and reporting systems at EU and national levels by 2020". The ESMERALDA project (funded by Horizon 2020) is aimed at supporting EU Member States in the MAES process.

"ESMERALDA (Enhancing ecoSysteM sERvices mApping for poLicy and Decision mAking) project (2015-2018) aims to deliver a flexible methodology to provide the building blocks for pan-European and regional assessments. The 
work will ensure the timely delivery to EU member states in relation to Action 5 of the BD Strategy, supporting the needs of assessments in relation to the requirements for planning, agriculture, climate, water and nature policy. This methodology will build on existing ES projects and databases (e.g. MAES, OpenNESS, OPERAs, national studies), the Millennium Assessment (MA) and TEEB. ESMERALDA will identify relevant stakeholders and take stock of their requirements at EU, national and regional levels."

For further information see:

- MAES: http://ec.europa.eu/environment/nature/knowledge/ecosystem assessment/index_en.htm; http://biodiversity.europa.eu/maes

- ESMERALDA project: http://www.esmeralda-project.eu/

- EU Biodiversity Strategy http://ec.europa.eu/environment/nature/biodiversity/comm2006/2020.htm

The Nordic study should consider throughout the assessment relevant commitments under Multilateral Environmental Agreements (MEAs), such as the CBD; and other relevant international commitments, such as the Sustainable Development Goals; as well as developments under regional agreements, such as OSPAR ${ }^{13}$ and HELCOM. ${ }^{14}$ Some EU tools, such as status reports under the Habitats, Birds, Water Framework and Marine Strategy Framework Directives may be useful, even if they may prove less relevant for Norway and Iceland.

The Nordic Assessment needs to work in synergy with and build on other assessments and reports, such as GEO-6, that have a more general focus; the EU MAES and ESMERALDA, see Box 3; Global Biodiversity Outlook; and the Nordic country's own related assessments and reports, such as national CBD reports, and national TEEB studies, see Annex 2.

Both scientific and indigenous and local knowledge should be considered in the Nordic Assessment, in accordance with IPBES rules and procedures. (For further information see the Rules of Procedure section, and regarding IPBES and indigenous and local knowledge systems see Box 5 in Annex 7).

The Nordic Assessment should, as far as possible, work closely with and use material from the IPBES relevant task forces, expert groups and

${ }^{13}$ http://www.ospar.org/
${ }^{14}$ http://www.helcom.fi/ 
the ECA, such as the guide to the production and integration of assessments (see IPBES/3/INF/4 and updated version, ${ }^{15}$ see also Annex 7, Box 2 "Guide on the production and integration of assessments").

\subsubsection{B. Geographic boundary of the assessment}

Figure 6: Nordic region

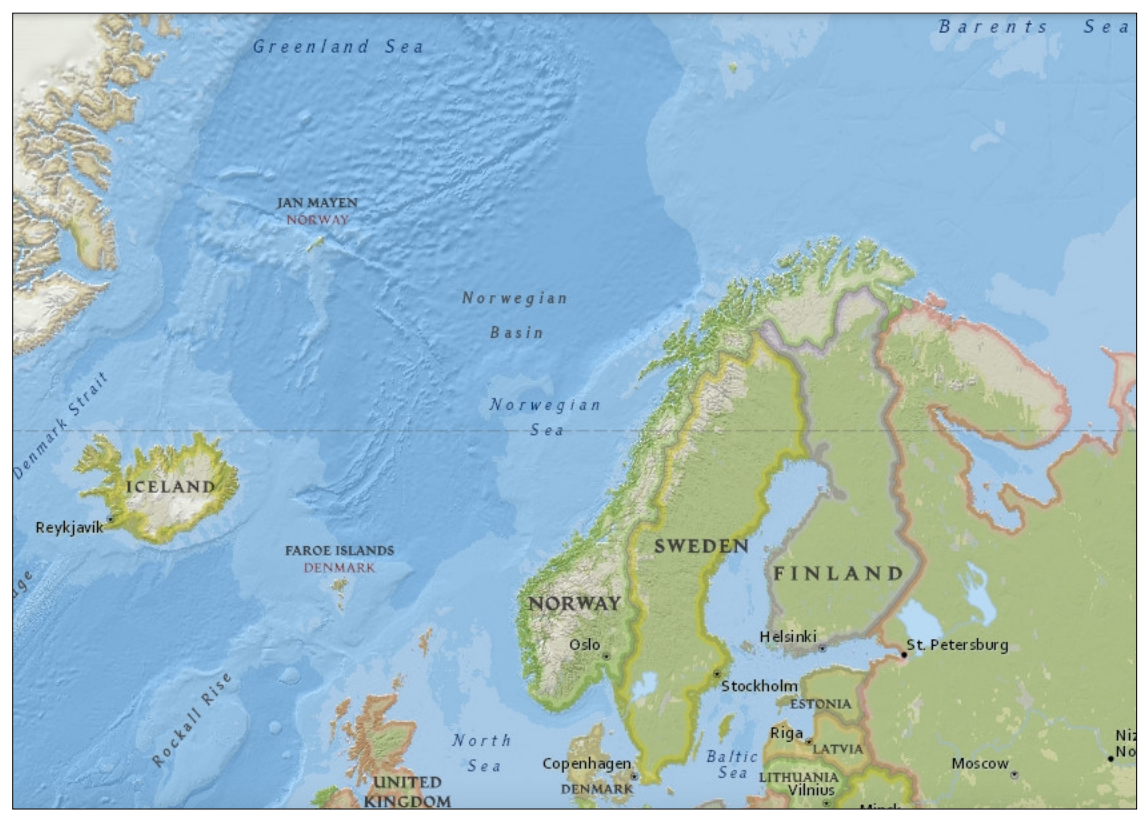

Note: The map shows the geographic location of the Nordic region and main seas. The Nordic region in this definition consists of the five countries of Denmark, Finland, Iceland, Norway and Sweden, as well as Svalbard, the Faroe Islands, Greenland and the Åland Islands.

Source: Map from National Geographic's MapMaker Interactive.

All the Nordic Countries, except Iceland, are members of IPBES. The Nordic countries are part of the IPBES specified sub-region Central and Western Europe, in the IPBES-specified Region Europe and Central Asia. The Nordic region includes Denmark, Finland, Iceland, Norway, Sweden and the Faroe Islands, Greenland and Åland, see Figures 6 and 7.

\footnotetext{
15 The guide includes guidance on dealing with scale, indicators, uncertainty terms, use of key methodologies (scenario analysis, consideration of value), how to address policy support tools and methodologies, and on the identification of capacity needs, gaps in knowledge and data, and protocols with regard to the integration of diverse knowledge systems.
} 
The Nordic region with Svalbard, Greenland and the Faroe Islands has Arctic areas within its territories (see Figure 8). The Arctic portal ${ }^{16}$ has interesting material and maps of the Arctic region. Conservation of Arctic Flora and Fauna (CAFF), the biodiversity working group of the Arctic Council, has recently produced an Arctic Biodiversity report ${ }^{17}$ of interest for the Nordic Assessment.

The Nordic Assessment should include marine areas of the Baltic Sea, Barents Sea, Norwegian Sea, Greater North Sea, Arctic Sea, and Greenland Sea. The inclusion of marine areas, both within and outside national jurisdiction, in the Nordic Assessment is important in order to be able to assess status of, trends in and threats to marine and coastal biodiversity, ecosystems, ecosystem services, and costs and benefits of utilising ecosystem goods and services in marine areas. Coastal seas are defined as areas within national jurisdiction up to the outer limit of the exclusive economic zone (EEZ), ${ }^{18}$ and open ocean or high seas are defined as beyond national jurisdiction.

In the Baltic Sea there are no waters beyond national jurisdiction, i.e. only national zone $<12$ nautical miles (nm) and EEZ $<200 \mathrm{~nm}$. In the Baltic Sea, no country has a distance of more than $200 \mathrm{~nm}$ from its baseline without overlap. In the Nordic region's vicinity there are, outside the Arctic, which is important to note, just two "holes" in the EEZ coverage with areas beyond national jurisdiction (ABNJ), see Figures 9 and 10 from OSPAR, everything else is EEZ. ${ }^{19}$

The Nordic Assessment should feed into the IPBES regional assessment for Europe and Central Asia as well as the IPBES Global assessment, and should be designed to avoid overlap with other assessment processes, such as the World Ocean Assessment. ${ }^{20}$ Furthermore, there is a need to consider relevant developments under regional agreements, such as OSPAR ${ }^{21}$ and HELCOM. ${ }^{22}$

Due to the character of biodiversity and ecosystems, it is important to complement governance according to public administration borders (for the obvious reason of legislation and governance systems, it is important

\footnotetext{
16 http://www.arcticportal.org/

$17 \mathrm{http} / /$ www.arcticbiodiversity.is/

${ }^{18}$ An exclusive economic zone (EEZ) is a sea zone prescribed by the United Nations Convention on the Law of the Sea over which a state has special rights regarding the exploration and use of marine resources, including energy production from water and wind. (Part V - Exclusive Economic Zone, Article 56. Law of the Sea. United Nations. Retrieved 28.8.2011.)

${ }_{19}$ e-mail correspondence with the Swedish Agency for Marine and Water Management (SwAM)

$20 \mathrm{http}: / /$ www.worldoceanassessment.org/

${ }^{21}$ OSPAR is the mechanism by which 15 Governments \& the EU cooperate to protect the marine environment of the North-East Atlantic.

22 http://www.helcom.fi/
} 
to take into consideration the form of states, county administrative boards or municipalities) with landscape planning (see for example Sweden's Regional Landscape Strategies or Marine Spatial Planning), watershed planning (as in the EU Water Framework Directive) ${ }^{23}$ or biogeographical regional planning. The biogeographical level makes it easier to conserve species and habitat types under similar natural conditions, and across a suite of countries, irrespective of political and administrative boundaries. ${ }^{24}$

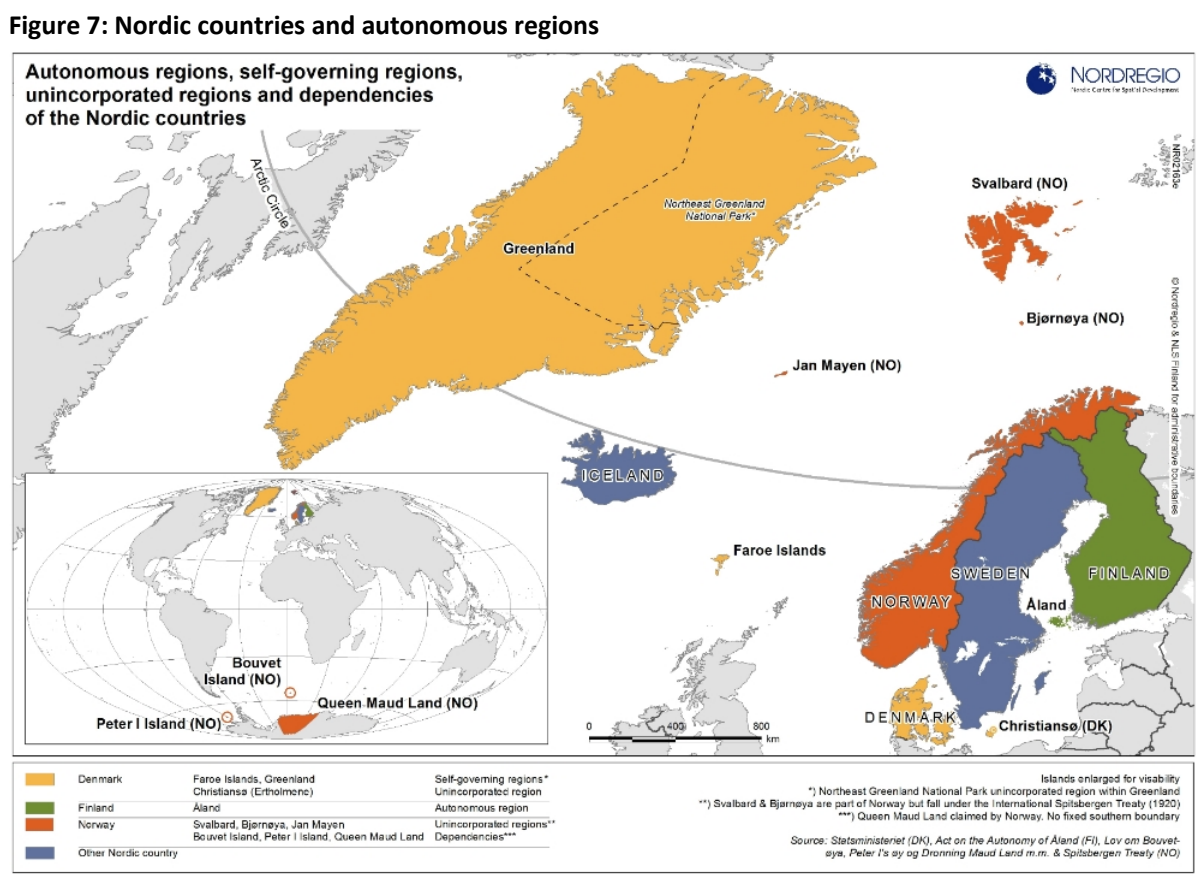

Source: Nordregio. Map ID: 10146e, Designer/Cartographer Linus Rispling, Data source, Statsministeriet (DK), Act on the Autonomy of Åland (FI), Lov om Bou-vetøya, Peter l's $\varnothing y$ og Dronning Maud Land m.m. \& Spitsbergen Treaty (NO), Published 25 June 2015. 
Figure 8: Arctic Boundaries and Definitions

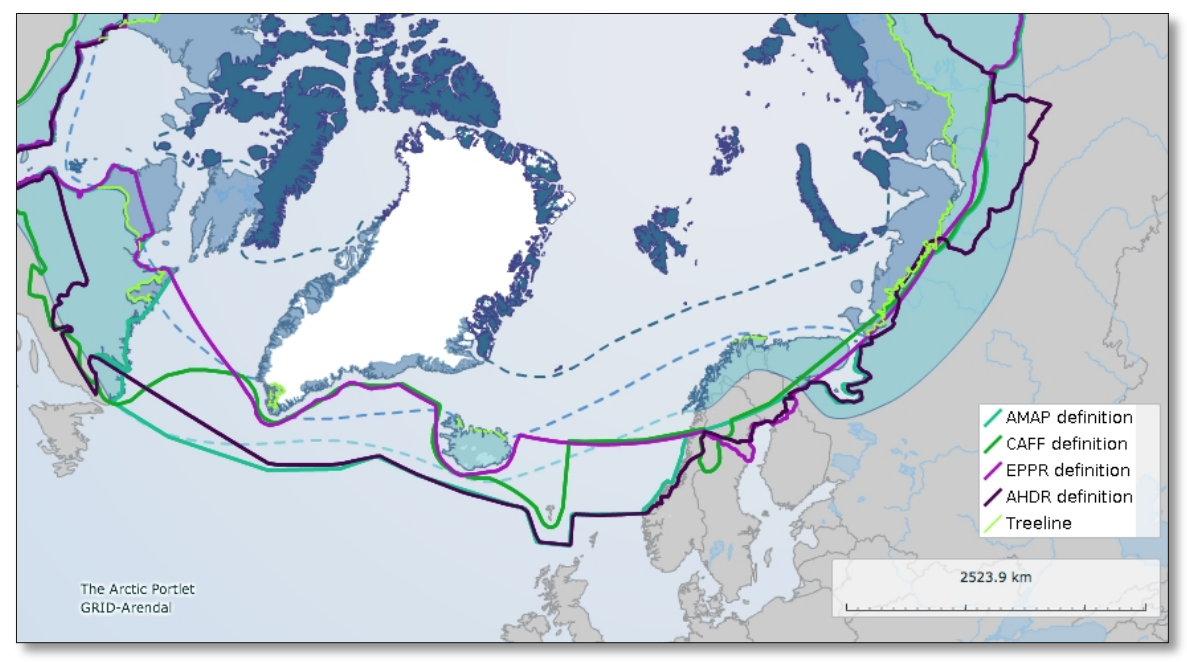

Note: Arctic Monitoring and Assessment Programme (AMAP); the Conservation of Arctic Flora and Fauna (CAFF); the Emergency Prevention, Preparedness and Response Working Group (EPPR); Arctic Human Development Report (AHDR).

Source: Arctic Portal. 
Figure 9: The North-East Atlantic, according to OSPAR commission

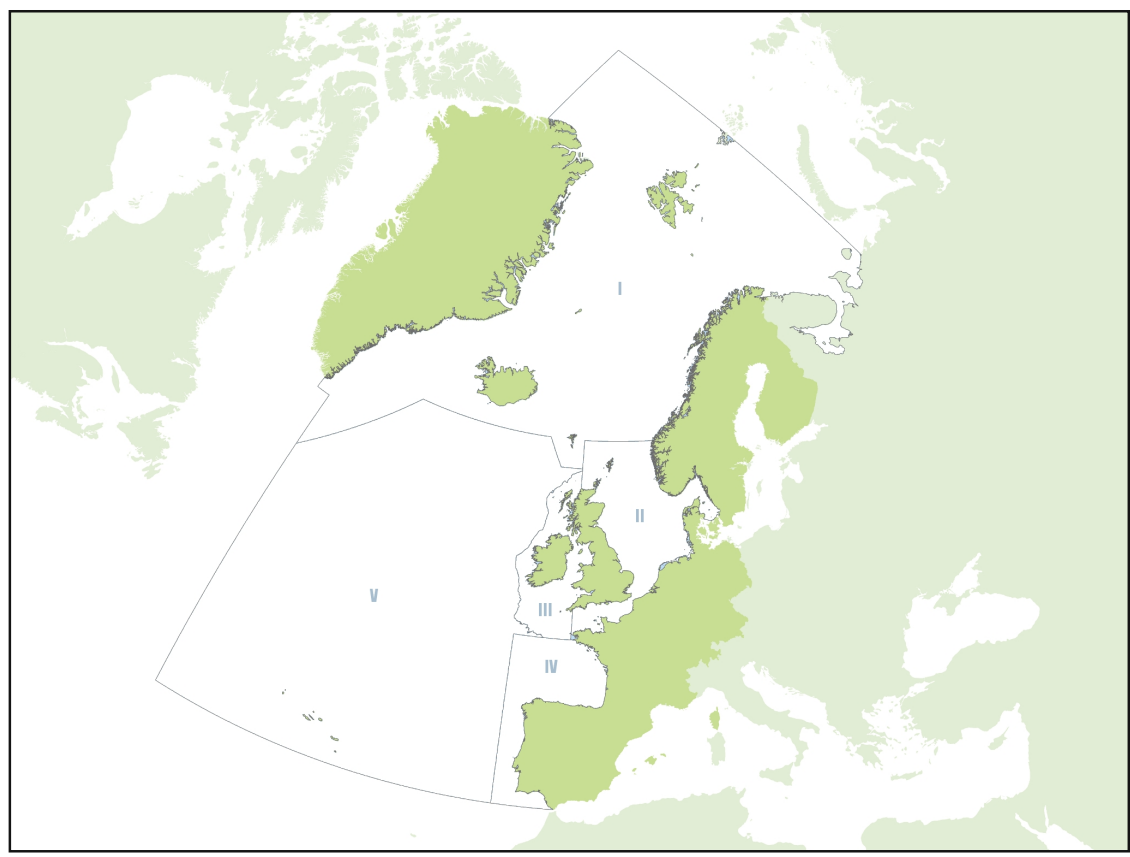

Note: Region I: Arctic Waters, the most northerly OSPAR region, is characterised by harsh climate and ice coverage, but the ecosystems of this region are rich, and human activities, such as fishing and offshore petroleum production, remain significant. Region II: Greater North Sea with offshore activities related to the exploitation of oil and gas reserves, maritime traffic are very important, the coastal zone is used intensively for recreation, and it is surrounded by densely populated, highly industrialised countries. The other regions on the map would not be covered by the Nordic Assessment of Biodiversity and Ecosystem Services: Region III: Celtic Seas; Region IV: Bay of Biscay and Iberian Coast; and Region V: Wider Atlantic.

Source: OSPAR. 


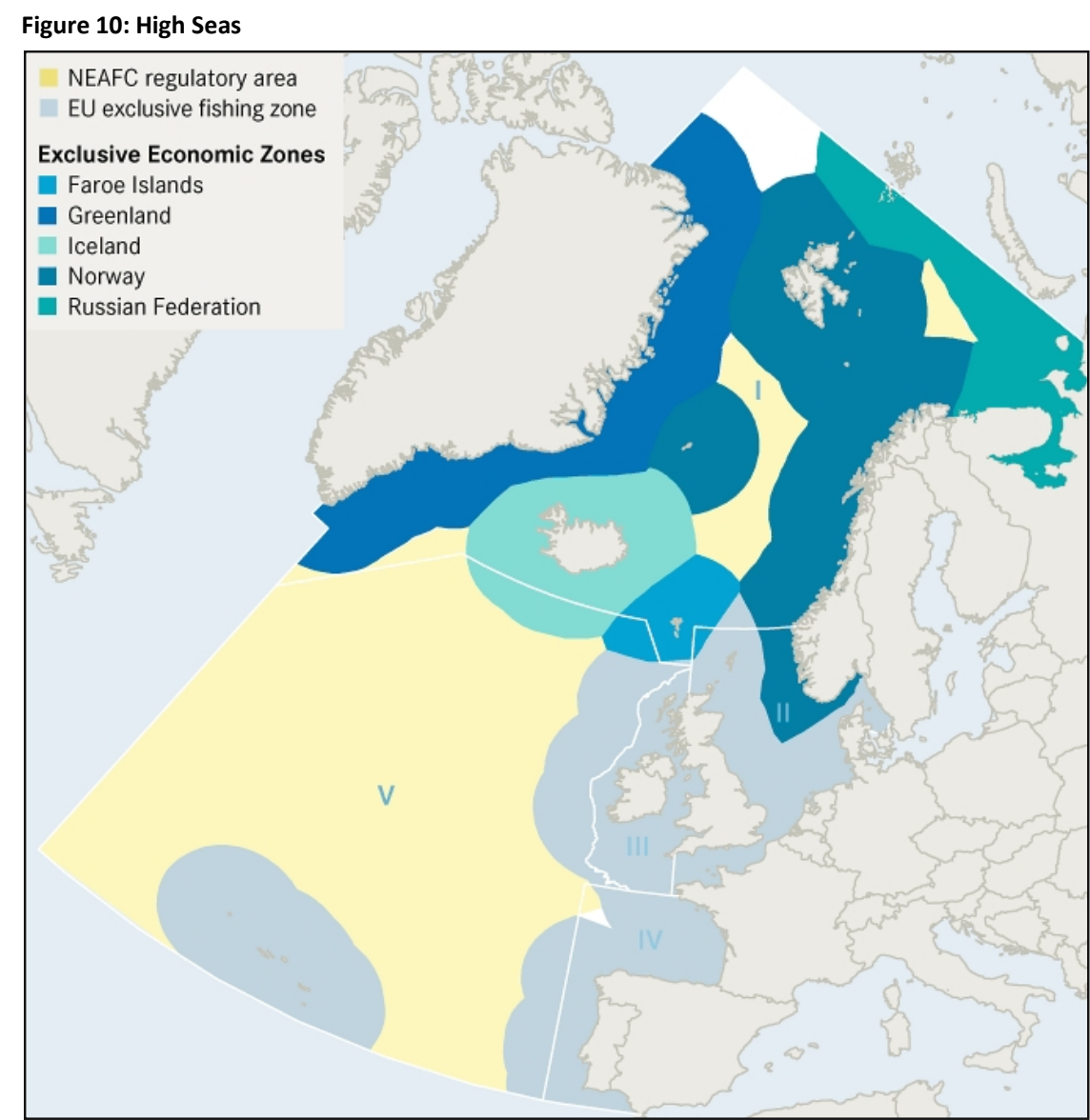

Note: (waters outside of national jurisdiction) are shown in yellow, the North East Atlantic Fisheries Commission (NEAFC) regulatory area. Grey areas are the EU-exclusive fishing zone. Ice-bound areas beyond national jurisdiction are shown in white.

Source: OSPAR Commission Quality Status Report 2010, (2010), Fisheries management zones in the OSPAR area (http://qsr2010.ospar.org/en/media/chapter_pdf/QSR_Ch08_EN.pdf).

An example of this is the biogeographical regions related to the Habitats Directive, see Figure 11. The European Union has nine biogeographical regions, with distinct vegetation, climate and geographic characteristics. Under the Habitats Directive, "Natura 2000" sites are selected on the basis of national lists proposed by the member states. For each biogeographical region the Commission adopts a list of Sites of Community Importance (SCI), which then become part of the network, and the SCIs are designated at the national level as Special Areas of Conservation (SAC). ${ }^{25}$ 
These biogeographical regions could potentially be applied to the Nordic Assessment since they are based on natural conditions. The boreal region might need better resolution; at least south boreal, middle boreal and north boreal. The Nordic TEEB study (Kettunen et al., 2012) indicates that biogeographically, the Nordic countries belong to the Palearctic region, with five biogeographical zones present in the area: arctic (Norway, Iceland, Greenland), alpine (Finland, Sweden, Norway), boreal (Finland, Sweden, Norway), atlantic (Norway, Denmark) and continental - nemoral (Sweden, Denmark), and that a boreo-nemoral zone (or hemi-boreal vegetation zone) marks the transition between the temperate deciduous forests of the nemoral zone and the coniferous forests of the boreal zone.

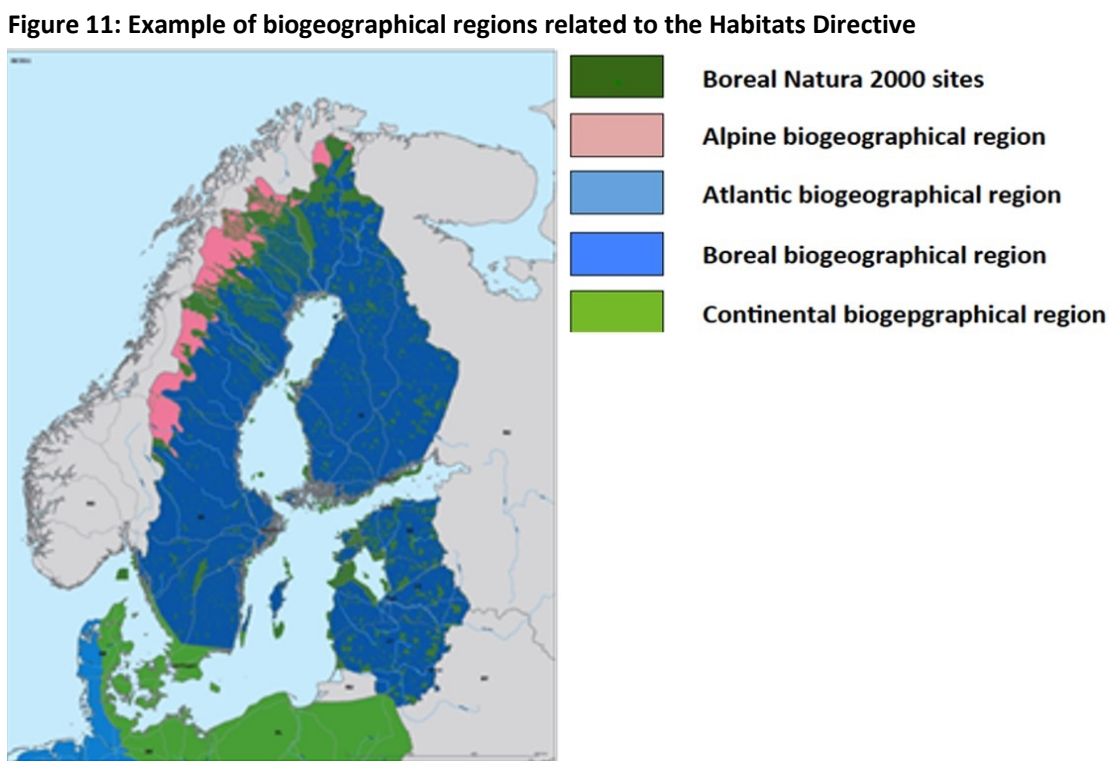

Source: EEA.

To illustrate the geographic variation within the Nordic countries, other gradients could also be used, and described in relation to the status of and trends in biodiversity:

- The climate gradient from southern nemoral zones, to northern high arctic zones.

- The aquatic gradient from the marine environment of the Atlantic Ocean, to the almost limnic conditions of the northern Baltic Sea. 
Further to that, indigenous peoples' and local communities' knowledge systems and governance practices do not follow borders; Nordic examples are the Sámi people in Norway, Finland and Sweden, the transhumance summer farmers in Norway and Sweden, as well as coastal fishing communities in the different countries with common traditions and fishing areas.

\subsubsection{Rationale}

Biodiversity and ecosystem services provide the basis for economies, livelihoods and good quality of life for people throughout the world.

Implementation of international commitments (such as the CBD's Aichi Biodiversity Targets, the post-2015 agenda and Sustainable Development Goals and regional policies, such as for the EU countries, the EU Biodiversity Strategy 2020) and national commitments require a strong knowledge base and strengthened interplay between scientists, policymakers and practitioners including a diversity of indigenous and local knowledge holders, that the Nordic Assessment would be well placed to contribute to. See Annex 3 for examples of the Nordic countries' laws and commitments. National Biodiversity Strategies and Action Plans are, for example, important vehicles for implementing the Aichi Biodiversity Targets and adapting them to regional and national conditions.

The Nordic Assessment would itself be a vehicle for implementation of the IPBES Platform's functions, as they relate to capacity-building, identification of knowledge gaps, knowledge generation and development of policy support tools. Furthermore, such assessments are critical to furthering the platform's operational principle of ensuring the full use of national, sub-regional, regional, and local knowledge as appropriate, including a bottom-up approach that ensures the contribution of practitioners and indigenous and local knowledge holders are taken into account and used as appropriate. Different ways of understanding, observing and using biodiversity, ecosystem services and functions can contribute to new insights in the IPBES process.

The assessment should address a number of international and regional issues of high priority embodied in global and regional agreements, in national policy and in societal expectations. Important priorities include issues covered by the four thematic assessments in the work programme of the IPBES Platform (pollinators, pollination and food production; land degradation and restoration; sustainable use and conservation of biodiversity and strengthening capacities and tools; and invasive alien 
species), in addition to sustainable agriculture, forestry, fisheries and biodiversity in areas sensitive to climate change.

The assessment of opportunities for mainstreaming, as well as obstacles and risks, through sector policies and new policy instruments (such as certification, labelling, offsetting, green infrastructure, national accounting or indicators, payment for environmental services schemes and social valuation) will be facilitated by Europe's and the Nordic countries' longstanding policy experience. This puts the region in an excellent position to assess policy impacts with a view to learning lessons and resolving issues relating to trade-offs and associated costs, including costs of policy inaction. The Nordic countries share a long history, and their political systems are quite similar, which makes a Nordic Assessment relevant and appropriate. One example is that there is a well developed fiscal system and a possibility of working with green incentives, such as taxes, fees and subsidies. One other similarity - for Sweden, Norway and Finland, and the Danish coastline - is the right of common access (allemansrätten), which provides better opportunities for the public to interact with nature. However, the extent of the right of common access varies from country to country, and in certain regions within a country there are different common access rights, such as between Åland and Finland. In contrast to most parts of the world, the landscape outside settled areas is accessible and people do not rely as heavily on protected areas for outdoor recreation as they do in many other countries.

The Nordic countries also have a long tradition of mutual co-operation, for example through the Nordic Council of Ministers and the Nordic Council, which is a Nordic co-operation that involves Denmark, Finland, Iceland, Norway and Sweden as well as the three autonomous areas, the Faroe Islands, Greenland and the Åland Islands. An assessment of the Nordic region will allow for the exploration of several transboundary issues, including water quality and quantity, fisheries, climate change, air pollution and migratory species. As discussed above in relation to biogeographical regions, the Nordic countries are nested social ecological systems. The Nordic Assessment should raise awareness of shared environmental issues and contribute to the better articulation of policy across the entire region.

\subsubsection{Utility}

The Nordic Assessment should, as far as possible, provide users with a credible, legitimate, authoritative, holistic and comprehensive analysis of the current state of scientific and other knowledge related to biodiversity 
and ecosystem services. Furthermore, this regional assessment will be relevant to the European Union's on-going efforts to map and assess the state of ecosystems and their services in national territory (MAES) which is of importance for the Nordic EU countries.

The assessment should build on multiple knowledge systems, as outlined in the Multiple Evidence Base approach ${ }^{26}$ (between academia, indigenous and local knowledge, citizen science, etc.), to gain better understanding of the links between biodiversity, ecosystem services and human well-being.

The assessment will also help identify capacity-building needs across the Nordic region. It should identify current gaps in capacity and knowledge and ways of addressing them at relevant levels.

The assessment should analyse options and policy support tools for sustainable management of biodiversity and ecosystem services under alternative scenarios and present success stories, best practice, and lessons learned. It should explore options for effective management and policy interventions at appropriate levels of governance.

The Nordic Assessment should support the Nordic countries and parties in implementing global, regional and sub-regional agreements (see Annex 3). It should address the CBD's Strategic Plan for Biodiversity 2011-2020 and its Aichi Biodiversity Targets at regional scales. The assessment could also support the implementation of national legislation at national and subnational levels.

It would strive towards providing clear methods and resources (data information and knowledge; strategic partner list; mechanisms for including indigenous and local knowledge) for national and local government to support sustainable development and improve human well-being by maintaining and improving ecosystem services.

The assessment should inform a broad audience, such as a range of stakeholders in the public sectors, private sectors and civil society. Outcomes of the Nordic Assessment should be presented as outlined in a communication strategy with detailed information including easy-tounderstand infographics, maps and geographical information systems' outcomes. Examples of available information are listed in Annex 2. The outputs should also include a summary for policymakers, highlighting

${ }^{26}$ A Multiple Evidence Base approach emphasises the complementarity of knowledge systems, without assigning any one knowledge system as the dominant one. See Tengö et al. 2014, Ambio 43, 579-591, http://dx.doi.org/10.1007/s13280-014-0501-3 
key policy-relevant findings. The information should be widely disseminated, including making use of new information and communications technologies. ${ }^{27}$

The Nordic Assessment should continuously feed into the official IPBES regional assessment for Europe and Central Asia, including support for the ILK processes and approaches linked to them. As well as delivering data and conclusions on biodiversity and ecosystem services, it may also make a contribution to the methodology of carrying out a regional assessment.

\section{E. Assumptions}

The assumptions underlying the Nordic Assessment include the availability of the necessary expertise and dependence on voluntary contributions to the initiative, including financial resources. It is assumed that sufficient, direct and in-kind funding, as well as technical support, will be available for the preparation and implementation of the assessment, but this is a risk, see further under "Risk Assessment".

The author expert groups for the Nordic Assessment should, in accordance with the IPBES procedures, reflect the need for disciplinary and geographic balance within the region. They should interact with each other, with similar groups undertaking global, thematic and methodological assessments in order to ensure conceptual and methodological coherence. They should also work as closely as possible with the IPBES-relevant task forces, expert groups and the ECA.

Experts involved in the Nordic Assessment should consist of both scientific and ILK holders and work closely with national centres of expertise, such as NAPTEK (a national programme on local and traditional knowledge related to the conservation and sustainable use of biological diversity at the Swedish Biodiversity Centre), the Sami Parliaments, Inuit organisations (e.g. the Inuit Circumpolar Council) and other relevant ILK organisations, and interact with the "Task Force on Indigenous and Local Knowledge Systems under IPBES" regarding exchange of experiences from methods and approaches to connecting across knowledge systems, and ensure that multiple sources of knowledge are drawn upon.

The Nordic Assessment should draw on and, when possible and appropriate, contribute to on-going and planned national and regional assessments, including those undertaken by TEEB and the MAES initiative,

\footnotetext{
${ }^{27}$ Examples to learn from are the Finnish website for ecosystem services: www.biodiversity.fi/ ecosystemservices/home, the Arctic Portals website for interactive maps http://portal.inter-map.com, and HELCOMs mapservice http://maps.helcom.fi/website/mapservice/index.html
} 
to value some services and integrate them into accounting systems by 2020 (accounting does not imply monetary valuation but can be in the form of aggregated indicators). In terms of environmental protection and sustainable use of ecosystem services, there is substantial sub-regional variation in the Nordic region. Attention should be given to different political and economic historical developments within and across the Nordic region. Differences in terms of economic and political development offer opportunity to transfer lessons between countries and subnational levels. For EU Member States, policy opportunities offered by a common governance system are of particular interest. Opportunities for policies and institutional arrangements for the recovery of degraded terrestrial and aquatic ecosystems, and for managing transboundary ecosystems, are particularly interesting.

\subsection{Key datasets}

The Nordic Assessment should draw on a wide variety of datasets addressing all specific components of the conceptual framework, see Figure 5. It should assess the state of knowledge relevant to the Nordic context.

The Assessment should be based on existing data, scientific literature, and other information, including citizen science, and indigenous and local knowledge. It should be gathered from the published literature, including grey literature according to IPBES guidelines. The amount of primary research that should be analysed has to be judged case by case, and depends on available resources, and the hierarchy of meta-analyses, systematic reviews, traditional literature reviews, and primary publications. Whether the source is trustworthy regarding reviews and synthesis, or if there is a need to compile the information from primary publications should also be determined. Contributions should be supported, as far as possible, with references from peer-reviewed and internationally available literature and with copies of any unpublished material cited, along with clear indications of how to access the latter. For material available in electronic format only, the location where such material may be accessed should be cited. Contributed material may be edited, merged and, if necessary, amended in the course of developing the overall draft text.28

Choice of time periods and validation methodologies for time series datasets should be rigorous and transparent. Discussion on how data may

28 Text refers to IPBES/3/18. 
influence values and conceptions in the final assessment should be included. It is a risk that the availability of data sources guides the assessment focus. It is important to try to identify gaps in knowledge and to understand what is unknown. It is important to present existing natural science knowledge and social and economic research, equally.

The Nordic Assessment would need to liaise with the IPBES task force on knowledge and data, and use the common framework on data standards developed in order to facilitate comparisons, especially concerning the use of common methodologies, measures and indicators, see Box 3 in Annex 7 on Data and information management plan under IPBES. A plan for how to handle data for the Nordic Assessment will be needed. The principles described in Box 3 in Annex 7, as well as the initial deliverables of the general data and information plan implementation, will offer guidance on this.

The Nordic Assessment needs to ensure the collection and archiving of corresponding metadata, and whenever possible, corresponding underlying data, through an interoperable sharing process to ensure comparability between assessments across regions. The data plan also needs to cover issues such as ownership of compiled data. Although it is a metadatabase, it might be necessary to have different types of options for access and use, and to establish some kind of agreement and different levels of logins, depending on metadata stored. The data plan needs to include a strategy for the use of data and knowledge that is not publicly available, such as local or traditional knowledge that cannot be shared outside the group of knowledge holders, or medical/psychological data collected with prior informed consent restricting the use of data, as well as for quality management. Whenever possible, the sets of metadata should contain information on the geographical location and temporal reference of the underlying data as well as the scientific and ILK protocol with which they were collected.

There is a need for a process to include ILK from different landscapes, biotopes and biological resources of the Nordic countries. This could be done through general and thematic dialogue workshops (sub-regional, national and local), in order to obtain ILK data, if resources are available. In cases where community-based monitoring is practised by holders of ILK, such as PISUNA and the Snowchange Deatnu Oral History Project, these sources should be welcome, based on free, prior and informed consent, to contribute to the Nordic Assessment.

It is important that the assessment employs methods to use soft data, fuzzy datasets and qualitative data in a reliable way. A particular challenge is to couple data of varying quality and resolution from different 
sources, for instance in building and using scenarios for evaluations and predictions. The application of scenarios covering large geographical areas and long time spans usually demands the availability of high quality datasets containing comparable data types.

Under IPBES Deliverable 3(c): Policy support tools and methodologies for scenario analysis and modelling of biodiversity and ecosystem services, are developed, for further information see Annex 7, Box 4 on "IPBES Scenario analysis and modelling". The Nordic Assessment should use spatiallyexplicit mapping and modelling methods. Existing remote sensing and biodiversity databases should be used to derive harmonised biodiversity variables of all the countries, when possible. The use of modern monitoring techniques for enhancing implementation of the Essential Biodiversity Variables (EBV) concept in ecosystem assessments (e.g. for CBD and IPBES) has been recently suggested (Skidmore et al., 2015; Vihervaara et al., 2015).

The Nordic Assessment would contribute to communicating data in a user-friendly manner for policy makers and other users, via innovative ways of communicating, such as interactive maps, etc. An interesting example of this is the Finnish Biodiversity and Ecosystem Service Indicators Portal. ${ }^{29}$

IPBES is working on a Catalogue of Assessments on Biodiversity and Ecosystem Services, ${ }^{30}$ which is a valuable source for the Nordic Assessment and may be aided by input from the potential Nordic Assessment.

Strategic partnerships with data holders should be developed and links to on-going knowledge generation initiatives and activities established.

The Nordic Assessment could use existing data and information held by global, regional, Nordic and national institutions and organisations, such as national academies of science, national research institutes, scientific societies and other research communities, research networks and projects, ${ }^{31}$ government environmental agencies and statistical offices and other bodies, such as the European Union MAES initiative, and ESMERALDA, ${ }^{32}$ the Copernicus programme of the European Space Agency, European Environment Agency, the Joint Research Centre, Eurostat, the Economic Cooperation Organisation, Global Biodiversity Information Facility, the Encyclopaedia of Life, the Group on Earth Observations Biodi-

\footnotetext{
${ }^{29}$ www.biodiversity.fi and www.biodiversity.fi/ecosystemservices

30 http://catalog.ipbes.net/

${ }^{31}$ Relevant research projects and networks include Biodiversity Multi-Source Monitoring System - from Space to Species, Multi-scale Service for Monitoring NATURA 2000 Habitats of European Community Interest, Future Earth, European Biodiversity Observation Network, Operationalisation of Natural Capital and Ecosystem Services, Ecosystem Science for Policy and Practice, the Ecosystem Services Partnership and A Long-Term Biodiversity, Ecosystem and Awareness Research Network.

32 http://www.esmeralda-project.eu/
} 
versity Observation Network and the International Union for Conservation of Nature, and Nordic-specific sources. During the Nordic introductory and scoping study, a simple Excel metadatabase with information on the main literature and sources identified for the Nordic Assessment forming annexes to this project plan has been constructed, see Annex 2 .

Since datasets are infinite, ranging from species lists of birds at single sites, to national forest inventories, and historical documents of land use etc., it is critical to decide and define what constitutes a relevant "key" dataset. The final delimitation of the assessment will determine the data needs and model framework, as well as eliciting existing research and data gaps.

\subsection{Citizen science and Indigenous and Local Knowledge systems}

The Nordic countries have a diversity of local cultures: local communities with customary uses of specific biological resources, often with artisanal techniques. In the Nordic countries there are two different indigenous peoples: the Sami and the Inuit. Farmers in marginal areas, pastoralists, fishermen, hunters and allotment growers are examples of other groups to be taken into account in the Nordic Assessment. Their knowledge is vital in order to develop, adopt and implement adequate local, national and international policies to arrest the current unprecedented decline in biodiversity and ecosystem services. The study performed by NAPTEK, linked to this introductory scoping study for the Nordic Assessment of Biodiversity and Ecosystem Services, had the task of assessing how to include both indigenous and local knowledge and citizen science in the potential Nordic Assessment.

The terminology indigenous and local knowledge (ILK) is a terminology used under IPBES. The classical definition of traditional ecological knowledge by Fikret Berkes (Berkes, 1993) is also a possible definition of indigenous and local knowledge (ILK) in a Nordic context: "a cumulative body of knowledge, practice and beliefs, evolving by adaptive processes and handed down through generations by cultural transmission, about the relationship of living beings (including humans) with one another and with their environment" (Tunón et al., 2015).

According to the Nordic ILK study (Tunón et al., 2015): citizen science is defined in the Oxford English Dictionary as "scientific work undertaken by members of the general public, often in collaboration with or under the 
direction of professional scientists and scientific institutions". The California Academy of Sciences offers the following definition: "Citizen science is a global movement through which scientists and non-scientists alike make observations, collect data, and help answer some of our planet's most pressing questions."

Citizen science and ILK are different entities. ILK, according to UNESCO's definition, "refers to the understandings, skills and philosophies developed by societies with long histories of interaction with their natural surroundings. For rural and indigenous peoples, local knowledge informs decision-making about fundamental aspects of day-to-day life. This knowledge is integral to a cultural complex that also encompasses language, systems of classification, resource use practices, social interactions, ritual and spirituality." The knowledge documented through citizen science, on the other hand, is typically in the form of distinct, closely defined data, from individual observations by interested citizens who have little or no connection with land management, which are then merged and analysed within a scientific framework (Tunón et al., 2015).

The outputs related to IPBES work programme deliverable 1 (c), procedures, approaches for participatory processes for working with ILK systems, is described in the document IPBES $4 / 7$ as forming a package that contributes towards the IPBES Platform's operating principle of recognition and respect for the contribution of ILK to conservation and sustainable use of biodiversity and ecosystems and include the following:

A. The approaches set out key principles that underpin all aspects of the Platform's work with ILK.

B. The procedures focus on bringing ILK into the Platform's assessments. They provide practical actions that enable the approaches to be implemented and that guide the appropriate inclusion of ILK from indigenous peoples, local communities and experts in assessment processes and outcomes.

C. The roster and network of ILK holders, from indigenous peoples and local communities, and ILK experts help identify individuals and organisations that may contribute to bringing such knowledge into the Platform's work.

D. The participatory mechanism provides an interface that facilitates participation of indigenous peoples and local communities in the Platform's processes and functions.33 
The capacity to perform these tasks could be strengthened through training, knowledge-sharing and collaborations between subregions and countries where needed.

The Task force on Indigenous and Local Knowledge systems under IPBES will provide guidance and procedures for the analysis and use of ILK under IPBES, see Box 1 and also Box 5 on Indigenous and local knowledge systems, in Annex 7. It is important to follow and adapt the work with the Nordic Assessment to advancements under the task force.

A Nordic network and supporting hub for ILK could be established to ensure sub-regional relevance and connection to ILK holders in the Nordic Assessment. ILK representatives need to be part of the assessment process from its design and throughout, including analysis and recommendations, such as outlined in the Multiple Evidence Base approach. ${ }^{34}$ The working procedure for a Nordic Assessment of Biodiversity and Ecosystem Services needs to be an iterative process, with sufficient time and opportunities for all ILK representatives to verify correctness and conclusions. It is important to give ILK representatives opportunities to reflect and comment upon other sections of the assessment, in the same way that researchers and governmental officials should be involved in the process. The role of ILK in the Nordic Assessment needs to be clearly stated, as well as the expected outcome of the participatory processes. It is important to ensure that holders of knowledge are obtaining meaningful outcomes from the process, in relation to their livelihood realities.

An important factor in order to achieve effective knowledge integration is the use of local languages and local consultations. In the consultation process within the ILK part of the Scoping Study, many ILK representatives mentioned linguistic barriers in participation of the work. There is a need for a series of Nordic, national and local dialogue workshops to be held in local languages, in order to obtain an initiated understanding of the reality of the different local communities and a diversity of inputs regarding the use of ecosystem services as well as their local status and trends.

In order to achieve full and effective participation from ILK representatives in a Nordic Assessment, it is necessary to take into consideration that each customary use has seasonal peaks when participation in exter-

${ }^{34}$ A Multiple Evidence Base approach emphasizes the complementarity of knowledge systems, without assigning any one knowledge system as the dominant one. See Tengö et al. 2014, Ambio 43, 579-591, http://link.springer.com/article/10.1007\%2Fs13280-014-0501-3 
nal processes is difficult or even impossible. It is therefore vital to correlate the consultation processes with the respective seasonal practices. In general, the summer months are not suitable for meetings.

It is important to consider the difference between ILK documented in a research project and the living knowledge in local communities. It is therefore important to have active consultation processes, which may be complemented by a review of the recorded data already available.

The IPBES process might also benefit from including experts in local cultures from historical associations or similar NGOs.

Within the Nordic countries, there are also several databases based on citizen science initiatives that could contribute highly relevant data on biodiversity and ecosystem services for a Nordic Assessment. This would also contribute a space for engaging with Nordic citizens expertise and commitment to biodiversity and ecosystem services. A Nordic Assessment should take advantage of databases and networks such as Artdatabanken, Artsobservasjoner, Floraväktarna and "Fugle og Naturbasen",35 for its data gathering, capacity building, communication and outreach activities. The examples above concern mainly "Nature". Related to "Nature's benefits to people" and "quality of life" there are also indirect drivers and policy options, and many others as well, such as outdoor recreation organisations, local development groups etc.

Community-based monitoring initiatives, where the local communities initiate or are part of projects regarding monitoring of local biological resources should be welcomed, based on free, prior and informed consent of the participating communities, to contribute to the Nordic Assessment. Examples are the PISUNA project in Greenland and the Snowchange Deatnu Oral History Project in Finland.

\subsection{Chapter Outline}

This chapter outline is quite detailed, due to the fact that this is an introductory study and some information and analysis is already presented now, and it should be said that the authors need to be able to work in a flexible manner and develop the texts under each chapter in conjunction with developments under IPBES and the Nordic societies.

${ }^{35} \mathrm{http} / / /$ www.fugleognatur.dk/ 


\subsubsection{Summary for policymakers}

The Nordic assessment needs a comprehensive summary for policymakers.

\section{Chapter 1: Setting the scene}

Chapter 1 should present the policy-relevant questions identified for the Nordic region in the Scope and how the Nordic Assessment reflects the IPBES conceptual framework. This includes the implementation of the Strategic Plan for Biodiversity and its Aichi Biodiversity Targets, see Annex 8 , and the Nordic region and countries' specific policy questions. It should present Nordic aspects of priority regarding the thematic challenges identified by the IPBES, such as land degradation and restoration, invasive alien species, and sustainable use of biodiversity. It should also outline the methodologies and approaches used in the assessment, including its approach to the use of different knowledge systems, and outline how the assessment identifies and addresses uncertainties and gaps in data and knowledge. It should identify relevant stakeholders, for which the regional assessment could be useful, and their respective priorities.

The assessment should focus on themes of most importance in a Nordic context and focus on commonalities, but also describe differences. As an introduction, this chapter should highlight the specific nature of the Nordic countries in terms of environmental policy, public planning and management. The Nordic context can be described in terms of social, cultural, legal, as well as abiotic and biotic environmental aspects. It is important to point out commonalities across the Nordic countries or in parts of the Nordic countries, such as common seas with the Baltic Sea; but also similar characteristics and aspects, such as outdoor life; and also aspects related to indigenous peoples, such as the Sami people and the Inuit. For further information, see section on Background and Introduction and Section I above.

The chapter should also make it clear that the ecological footprint of the Nordic countries extend beyond the subregion, and that we are equally concerned with conservation and sustainable use of biodiversity occurring outside the Nordic countries, which are affected by our way of life. A full assessment of this ecological footprint will not be possible in the assessment, but reasoning and cases can be included.

\section{Chapter 2: Ecosystem Services and Human Well-being - (Nature's benefits to people and Good quality of life)}

Chapter 2 reflects the conceptual framework boxes, Ecosystem Services ("Nature's benefits to people"), Human Well-being ("Good quality of life"), and fluxes between them. 
The chapter should begin with an exploration of the concepts "human well-being" and "good quality of life". The terms ecosystems services, nature's benefits, or nature's gifts also need to be described, as well as the history behind the concepts. Nature and humans co-produce ecosystem services or benefits, which is not very clear in the conceptual framework. This intertwined relationship is well described in Folke et al. (2011, p.40):

"In a globalised society, there are no ecosystems without people and no people that do not depend on ecosystem functioning. They are intertwined and thus, ecosystem services are generated by social-ecological systems. Socialecological systems are dynamic and connected from the local to the global, in complex webs of interactions subject to gradual and abrupt changes. Dynamic and complex social-ecological systems require strategies that build resilience rather than attempting to control for optimal production and shortterm gain in environments assumed to be relatively stable. The shift from people and nature as separated parts to interdependent social-ecological systems provides exciting opportunities for societal development in tune with the biosphere; a global sustainability agenda for humanity."

The terminology ecosystem services was more or less invented to indicate that it is not just goods that the ecosystem produces but also a variety of functions humans are dependent on.

The chapter should assess the relationships and impacts of changes regarding nature's benefits to people with regard to food security, energy security, livelihood security and health security and identify aspects of biodiversity and ecosystem functions and services that are critical to social relationships, spirituality and cultural identity. It should also address issues of equity, including intergenerational equity.

The assessment should address innovation and nature-based solutions and how they are and can influence the job market in the region.

The chapter should include the notion of biocultural diversity - the diversity of life in all of its manifestations: biological, cultural, and linguistic, which are interrelated (and co-evolved) within a complex social-ecological adaptive system and that have developed over time through mutual adaptation between humans and the environment at the local level, possibly of a co-evolutionary nature (Maffi, 2010).

The chapter should examine the multiple values of biodiversity and ecosystem services, and the assessment should consider strategies for valuing ecosystem services in qualitative, quantitative, and monetary terms. There is a need also to study the underlying values and attitudes, other than utilitarian values, related to biodiversity and ecosystem services. Do, and if so how do, the utilitarian values relate to root causes of biodiversity loss? In the process of developing the scoping the intrinsic 
value of biodiversity was valued as important. The valuation of ecosystem services is linked to the values held by the persons and society that value them - values are not absolute, but rather are assigned by people, and different people will recognise different values of biodiversity components. Values also change along a gradient of organisational scale - an individual person, a group of stakeholders, and a national government may view the value of a particular component of biodiversity quite differently. The concept of the value of biodiversity and ecosystem services hence needs to be explored and problematised, and an assessment of such values should relate the values to the relevant context as well as identifying persons and organisations that assigned the value. See Figure 12 for examples of different kinds of assessments of values.

Figure 12: Different kinds of assessment are appropriate for different kinds of values

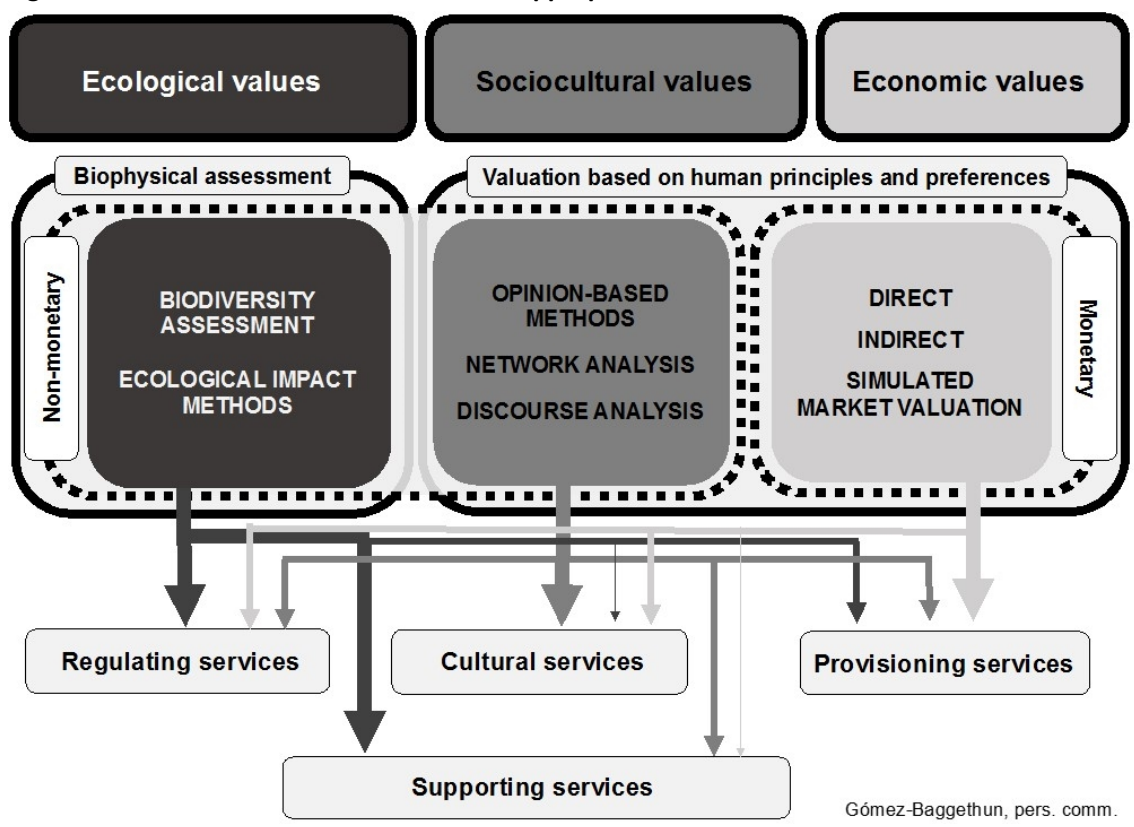

Note: Figure courtesy of E. Goméz-Baggethun.

Source: Gómez-Baggethun et al., 2016.

The chapter should assess the values of ecosystem services, including the interrelationship between biodiversity, ecosystem services and society; the geographical difference between the production and use of ecosystem services; and as the status, trends and future dynamics of ecosystem services. This should not be limited to services that are currently highly valued, but also attempt to consider changes and uncertainties in how they 
will be valued in the future. In relation to this, the insurance value (or resilience value), multifunctionality and contingency value of ecosystems are of interest. The "insurance value" refers to the ability of ecosystems and biodiversity to provide ecosystem services in times of change. This value can be very high for ecosystem services that are difficult to replace, and many assumptions are required to make a valuation.

This chapter should also assess the multifunctionality of landscapes and bundles of ecosystem services (Huitric et al., 2009), see Figure 13. Ecosystems have the ability to produce multiple ecosystems simultaneously. Maximising the production of a single service, e.g. production of a monoculture crop, can have negative impacts on other services. In Figure 13 below, a filled petal in a flower diagram represents the maximum production of a service. The flower diagram illustrates synergies and tradeoffs between different services. It is also important to understand the underlying ecosystem functions or services that one service is dependent on - for example, apple production is dependent on pollination.

Figure 13: Multifunctional landscapes and bundles of ecosystem services

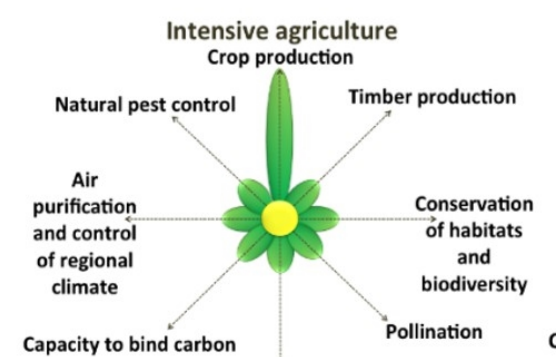

Capacity to bind carbon

Water purification and control of water flows

Natural ecosystems Crop production

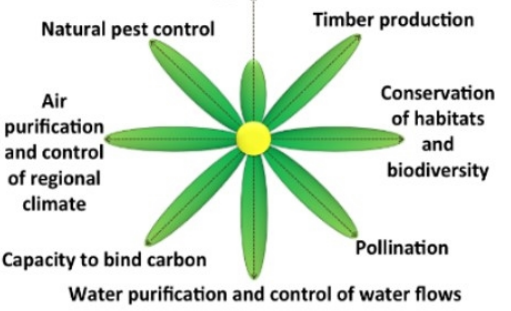

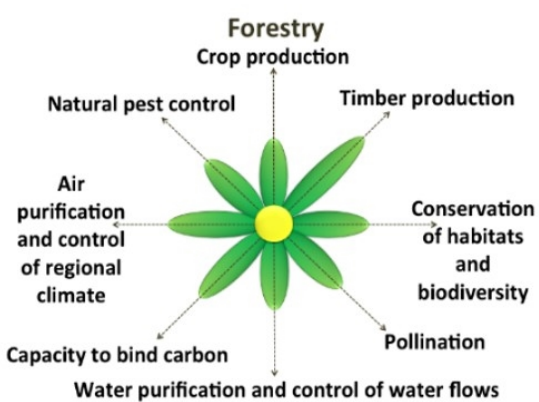

Water purification and control of water flows

Note: An illustration of variations in the provision of ecosystem services in ecosystem service bundles with different land uses.

Source: Adapted from Foley et al., 2005 and original illustration by C. Cliffstock. 
Nordic countries have undertaken several studies regarding valuation of ecosystem services. One example is the Official Norwegian Report NOU 2013: Natural benefits - on the values of ecosystem services, published by: Norwegian Ministry of the Environment. The Norwegian Expert Commission on Values of Ecosystem Services was appointed in October 2011. In summary, the Commission's mandate was to assess: 1) To what extent the concepts and conclusions from the TEEB project are relevant to Norway; 2) The state and development of Norwegian ecosystems and ecosystem services; 3) Methods to demonstrate the importance of the ecosystems and ecosystem services; and 4) Whether the framework conditions under which private and public decision-makers act adequately convey the importance and scarcity of ecosystems and ecosystem services. ${ }^{36}$

Another example is the Swedish Government Inquiry SOU 2013:68, which demonstrated that ecosystem services can be valued by identifying important ecosystem services and users, and by mapping the ecosystem services, see Figure 14. The inquiry found that this work may in itself provide an important basis for decisions. Furthermore, measuring the value of ecosystem services in monetary terms can sometimes help make them visible and ensure that benefits of biodiversity and ecosystem services are effectively taken into account in decision making. The inquiry stressed that monetary valuation is less reliable, or even inappropriate, in complex situations that involve a variety of ecosystem services, or where there are different ethical convictions regarding what values it is possible or appropriate to express monetarily, and that this applies especially to the supporting and regulating ecosystem services that determine the long-term capacity of ecosystems to generate human well-being (e.g. soil formation, water regulation, or pollination). It further stated that uncertainty about ecological relationships and potential threshold effects needs to be described and communicated in a comprehensible manner. ${ }^{37}$

\footnotetext{
36 https://www.regjeringen.no/contentassets/c7ffd2c437bf4dcb9880ceeb8b03b3d5/ en-gb/pdfs/nou201320130010000engpdfs.pdf

${ }^{37}$ Making the value of ecosystem services visible - Proposals to enhance well-being through biodiversity and ecosystem services, Summary of SOU 2013:68 Stockholm 2013.
} 


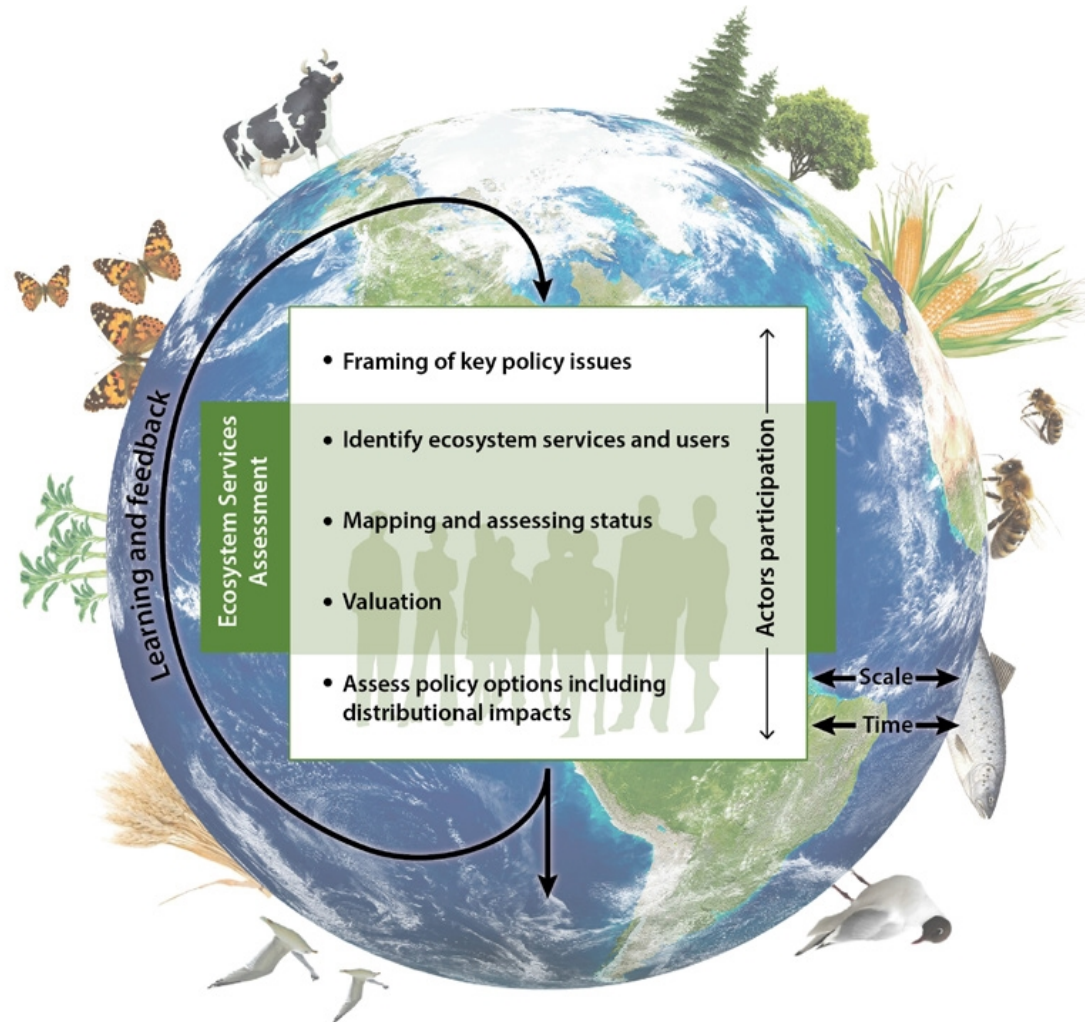

Note: The valuation of ecosystem services can be done by identifying important ecosystem services and users, and by mapping the ecosystem services.

Kilde: Making the value of ecosystem services visible - Proposals to enhance well-being through biodiversity and ecosystem services, Summary of SOU 2013:68 Stockholm 2013.

Illustration: J. Lokrantz/Azote.

In Finland, the report "Towards A Sustainable and Genuinely Green Economy - The value and social significance of ecosystem services in Finland" (TEEB for Finland), synthesis and roadmap, (Jäppinen \& Heliölä, 2015), presents the results of a research project, financed by the Finnish Ministry of the Environment. This project aimed to initiate a systematic national process for the integration of ecosystem services and related biodiversity (i.e. natural capital) into all levels of decision-making. TEEB for Finland was carried out according to the models of previous international TEEB studies (e.g. TEEB Nordic) and alongside the EU's MAES project. The study has produced information and knowledge for the implementation of the Finnish National Biodiversity Strategy and Action Plan (NBSAP) 20132020, "Saving Nature for People", for reporting of national actions con- 
nected to the Convention of Biological Diversity (CBD) Strategic Plan for Biodiversity 2011-2020, the EU's Biodiversity Strategy 2020, and their obligations regarding ecosystem services and natural capital.

Figure 15: Schematic picture of the guide regarding diverse conceptualisation of multiple values of nature and its benefits, including biodiversity and ecosystem functions and services

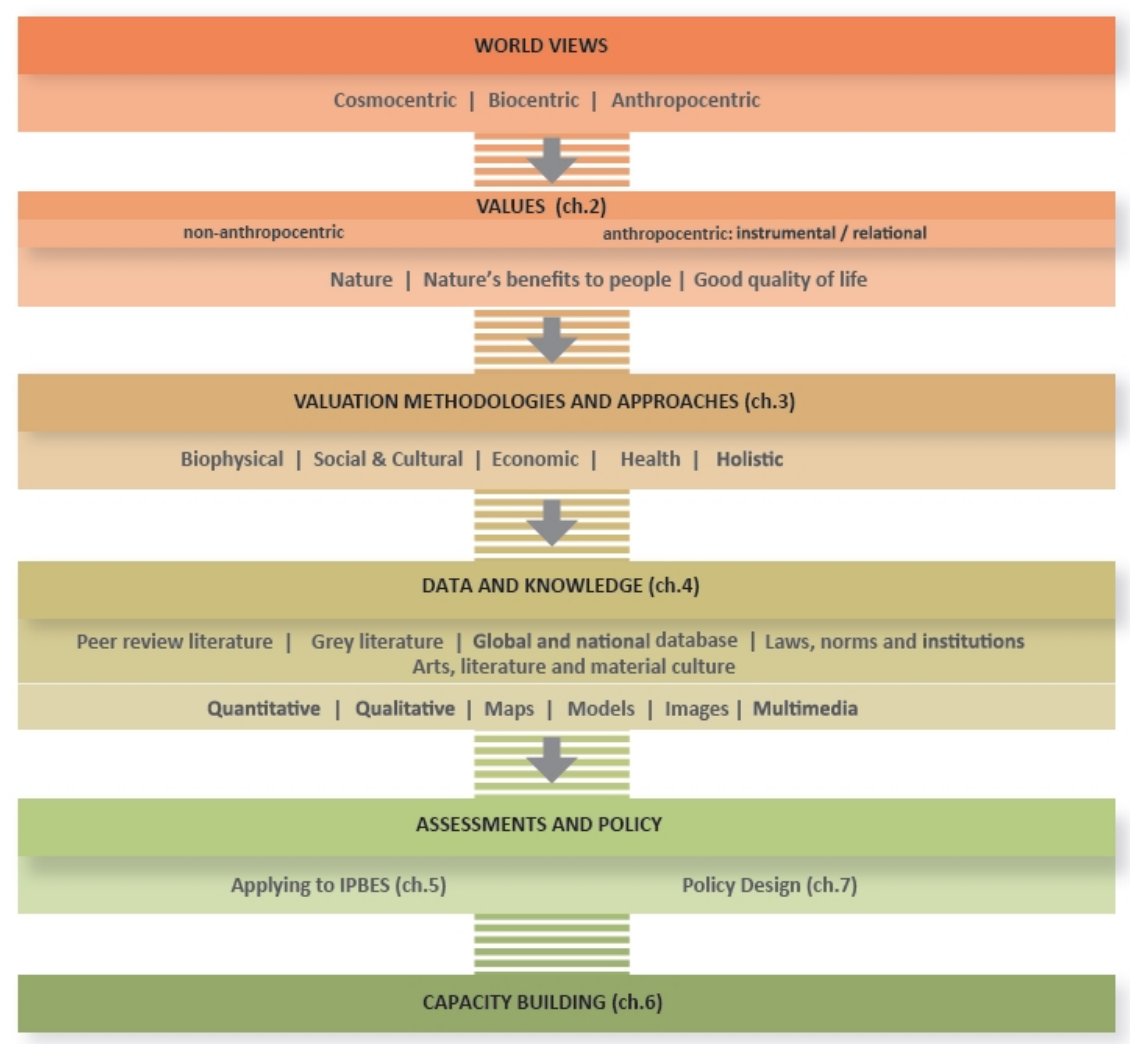

Note: The different sets of rows show the different types of world views, values and foci of value, valuation methodologies and approaches, data sources, and data types. The choice of a particular world view can be associated with various types of value and relate to all the foci of value, for which particular approaches, data sources and data types are needed. The large number of possible combinations is represented here by a generic arrow linking the different sets of rows.

Source: IPBES/3/INF/7 Preliminary guide regarding diverse conceptualisation of multiple values of nature and its benefits, including biodiversity and ecosystem functions and services (deliverable $3(d))$.

The value of ecosystems need to be visualised on different levels: Nordic, national and local. It should apply methods described in the guide for assessments, IPBES deliverable 2 (a) and interact closely with the thematic assessments in deliverable 3 (b). This chapter links to IPBES documents such as: preliminary guide regarding diverse conceptualization of multiple values of nature and its benefits, including biodiversity and ecosystem 
functions and services (deliverable 3 (d)).38 For further information, see Annex 7, Box 6 on "Guide regarding diverse conceptualisation of multiple values of nature and its benefits, including Biodiversity and ecosystem functions and services" (deliverable $3 \mathrm{~d}$ ), and also Figure 15.

The chapter reflects in particular Goal D, "Enhance the benefits to all from biodiversity and ecosystem services", of the Strategic Plan for Biodiversity under CBD and will address issues related to the three Aichi Targets under this goal (Aichi Targets 14,15 and 16) as well as Target 18, see Annex 8 Aichi Biodiversity Targets.

\section{Chapter 3: Status, trends and future dynamics of biodiversity and ecosystems underpinning nature's benefits to people}

Chapter 3 should reflect the conceptual framework Box "Nature", emphasising the components and fluxes impacting on "Nature's benefits to people". It should assess status and what is known about past and current trends, and future dynamics of biodiversity and ecosystems, and their positive and negative effects on key ecosystem services identified in Chapter 2. It should also identify patterns and processes relevant to longterm persistence of biodiversity and also resilience.

The timeframe of analyses should cover current status, trends (going back in time several decades, for ECA discussed in the 1950s) and future projections, with a focus on periods ranging from 2020 to 2050.39

This chapter should consider biodiversity at all levels, from genetic to species to ecosystems. It should also look at landscape composition and distribution of biodiversity, including the distribution of fragile habitats and hotspots as well as species of special concern and importance, such as species listed under Convention on International Trade in Endangered Species (CITES), migratory species as listed by CMS, and International Union for Conservation of Nature (IUCN) threatened species, as well as species listed at the national level, wild species, domesticated and managed.

Biodiversity is made up of unique components (individuals, species or ecosystems), and this information should be retained in any analysis. For example, the number of species in an area may remain stable while the actual composition of species changes dramatically. Species contribute differently to the overall functioning of ecosystems and changing species assemblages may also eventually affect ecosystem service provisioning.

The chapter should also address the functional properties of different species assemblages and how these connect to ecosystem services and

\footnotetext{
${ }^{38}$ http://www.ipbes.net/images/documents/plenary/third/information/INF_7/IPBES_3_INF_7.pdf

${ }^{39}$ Which cover key target dates related to the Strategic Plan for Biodiversity of the Convention on Biological

Diversity and the on-going process of developing the post-2015 development agenda.
} 
livelihoods. This understanding could be sought through a different analysis of biodiversity, one based on the presence and distribution of different functional (life history) traits rather than just genetic or species diversity. This can present a more direct functional link between biodiversity, ecological functions, and the resilience of both.

This chapter should consider the status of and trends in biodiversity at multiple scales and all types of landscapes, including urban areas. For example, connectivity and modularity (the degree to which components of a system form subgroups of internally well-connected but externally disconnected clusters (Biggs et al., 2012)) could be considered in this chapter. These could be interesting concepts when discussing, for example, green infrastructure.

The chapter should consider successional series and stages as captured by the adaptive cycles. Holling (1986) outlined a model, which he called the adaptive cycle, that consists of an infinity loop of four phases: exploitation, conservation, release and reorganisation. The adaptive cycle is nested in time and space. The adaptive cycle can contribute to the analysis and assessment of complex social ecological systems, innovation, adaptation, and transformation which is an on-going requirement of resilient systems (Gunderson and Holling 2002, Folke 2006).

The geographic boundary of the assessment is described under Section B. of this project plan. The chapter may be structured using a classification of biogeographical regions and/or land uses.

The chapter reflects in particular Goal C: "To improve the status of biodiversity by safeguarding ecosystems, species and genetic diversity" of the Strategic Plan for Biodiversity, and will address issues related to the three Aichi Targets under this goal (Aichi Targets 11,12 and 13), as well as relevant aspects of Aichi Target 14, see Annex 8 Aichi Biodiversity Targets.

\section{Chapter 4: Direct and indirect drivers of change in the context of different perspectives of human well-being (quality of life)}

Chapter 4 reflects the conceptual framework boxes and fluxes on "Institutions and governance and other indirect drivers" and "Direct drivers". The chapter should assess the status, trends and future dynamics of indirect and direct drivers, focusing on those affecting "Nature", "Nature's benefits to people" and how that links to "Good quality of life". The chapter should also analyse the interrelations between and among direct and indirect drivers.

An initial section of the chapter should explore the concept of direct and indirect drivers, and map the main ones in the Nordic region. Direct drivers include, for example, habitat conversion, use of aquatic resources 
including through fisheries, land management practices, extractive industries and infrastructure projects, use of wild species, pollution, invasive alien species, and the impacts of climate change. Indirect drivers include, for example, policy changes, changes in economic activity, population change and technology change.

Consideration should be given to how institutional and governance arrangements, see also Chapter 6, contribute to changes in biodiversity, ecosystem functions and ecosystem services. Both direct and indirect drivers may work as pushing or pulling forces, i.e. some drivers cause a directional change, whereas others preserve the present biodiversity and ecosystem services.

Emphasis should be placed on the most relevant aspects for the Nordic region of for example land degradation and restoration, agriculture intensification (with a discussion on unsustainable and sustainable practices). For relevant work conducted under IPBES related to land degradation, invasive alien species, and sustainable use, see Annex 7, Box 7.

Major links with other regions should be assessed, including, as far as possible, an analysis of the global ecological footprint of the Nordic countries.

The chapter reflects in particular Goals A and B of the Strategic Plan for Biodiversity and should address issues covered by the Aichi Targets under this goal (in particular Aichi Targets 4, 5, 6, 7, 8, 9 and 10), see Annex 8 Aichi Biodiversity Targets.

\section{Chapter 5: Integrated and cross-scale analysis of interactions of nature and human society}

Chapter 5 reflects all the boxes and fluxes of the conceptual framework. Although the figure cannot be changed, the Nordic Assessment should handle more processes and dependencies than expressed with the arrows in the conceptual framework of IPBES. It should build on the analysis in the previous chapter and make extensive use of scenarios and modelling in its analysis. This includes analysis at and across different scales such as local, national and Nordic, as well as the links to the global scale. For some aspects, national or local division in accordance with political and management systems is appropriate. For other aspects, biogeographical regions might be more appropriate to capture cross-border inter-connected issues relevant to biodiversity and ecosystem services.

Regarding scale and cross-scale dynamics, it is critical to fit relevant patterns and trends to the scales where they are best addressed. Biodiversity is nested in space and time, and understanding the nature of these relations is crucial to understanding policy needs. Targets, frameworks and data need to be formulated in a comprehensive hierarchy where local 
initiatives and studies can easily communicate with regional or national ones, and vice versa.

This chapter should, as far as possible, include analysis of dynamics, including feedbacks (see Figure 16), time-lags, tipping points, cross-regional interrelations, synergies and trade-offs. It should focus on the key issues that could determine the dynamics of the interactions between society and nature (the social-ecological system) over the next 40 years in accordance with the IPBES scoping report for the regional and subregional assessments.

The chapter should explore various paths towards sustainable development, explore changes in the trajectories of multiple drivers and the role played by adaptive behaviour. For example, solutions related to climate change might have positive impacts for one group in society but harm biodiversity and ecosystem services related to another user group. See Table 3 for examples of synergies and trade-offs identified in the Nordic TEEB (Kettunen et al., 2012).

Table 3: Some identified key synergies and trade-offs between different ecosystem services and biodiversity and ecosystem services in the Nordic countries

\begin{tabular}{|c|c|}
\hline Synergies & Trade-offs \\
\hline $\begin{array}{l}\text { Recreation } \leftrightarrow \text { provisioning of berries, mushrooms } \\
\text { and game }\end{array}$ & $\begin{array}{l}\text { Provisioning of agricultural products/timber } \leftrightarrow \\
\text { biodiversity, recreation }\end{array}$ \\
\hline Recreation $\leftrightarrow$ mental health and identity & $\begin{array}{l}\text { Provisioning of agricultural products } \leftrightarrow \\
\text { purification of water }\end{array}$ \\
\hline $\begin{array}{l}\text { Sustainable forestry } \leftrightarrow \text { recreation, provisioning of } \\
\text { game, berries and mushrooms }\end{array}$ & $\begin{array}{l}\text { Hunting game (bear, wolves, whales) } \leftrightarrow \\
\text { wildlife tourism, biodiversity }\end{array}$ \\
\hline $\begin{array}{l}\text { Extensive / sustainable agriculture } \leftrightarrow \text { pollination, } \\
\text { recreation and tourism, purification of water, } \\
\text { biodiversity }\end{array}$ & $\begin{array}{l}\text { Climate change mitigation (carbon storage) } \leftrightarrow \\
\text { timber and wood production }\end{array}$ \\
\hline $\begin{array}{l}\text { Climate change mitigation (carbon sequestration) } \\
\leftrightarrow \text { timber and wood production }\end{array}$ & $\begin{array}{l}\text { Bioenergy (forests) } \leftrightarrow \text { carbon sequestration, soil } \\
\text { fertility, nutrient cycling, biodiversity }\end{array}$ \\
\hline $\begin{array}{l}\text { Sustainable forestry } \leftrightarrow \text { recreation, provisioning of } \\
\text { game, berries and mushrooms }\end{array}$ & Provisioning of timber $\leftrightarrow$ reindeer herding \\
\hline & $\begin{array}{l}\text { Peat extraction } \leftrightarrow \text { recreation, aesthetic values, inland } \\
\text { water fishing, carbon storage, biodiversity }\end{array}$ \\
\hline
\end{tabular}

Source: Nordic TEEB, 2012 (Kettunen et al., 2012). 


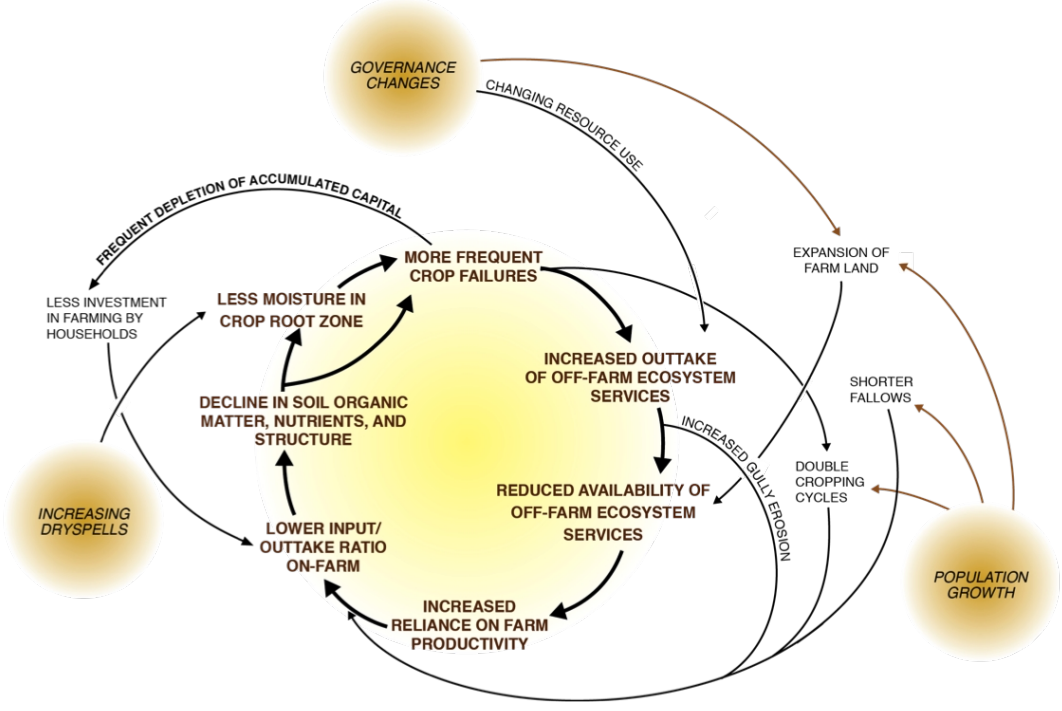

Note: Illustrating how drivers of change (population growth, increasing dryspells, and central governance changes) have interacted with a set of key system variables in a process that over time has reduced the productive potential in this specific agricultural system. The figure can also illustrate how external drivers (e.g. improper policies, and unclear tenure rights) can dominate and impede on communities' efforts to improve their systems.

Source: Source: Enfors, 2013.

It is important that the scenario and modelling approach explore a set of different circumstances with different assumptions and options to solve a problem. It is a particular challenge to build models that can employ a combination of quantitative and qualitative data as input, and that will capture the complexity of the real systems. It is not self-evident what the dependent variable of such models should be, that is, what are we looking for. Should it be human well-being, aspects of biodiversity, or quality and quantity of ecosystem services? For all of these a range of different specific measurements would be available. The process of choosing model complexity, input variables, and output variables is not trivial. The assessment should explore both answers to the questions below and methods for looking for answers. One example of a useful approach is the seven principles for building resilience identified in Box 4 . 
Box 4. Applying resilience thinking (From Biggs et al., 2012; Biggs et al., 2015)

\section{Principle one: Maintain diversity and redundancy}

Systems are made up of many different components (they can be species, land use patches or sources of knowledge), and systems with many components are generally more resilient than those with few components. Diversity makes redundancy more likely, i.e. the system containing components that can compensate for the loss or failure of others.

\section{Principle two: Manage connectivity}

Connectivity between components is a double-edged sword. While well-connected systems can recover from disturbances more quickly, overly connected systems facilitate rapid spread of disturbances. Intermediate connectivity with semi-autonomous but internally well-connected subsystems may be a workable compromise.

Principle three: Manage slow variables and feedbacks

Environmental quality, e.g. drinking water of good quality, is often linked to slowly changing variables. Although the variables themselves change slowly, the system response to change can be sudden and difficult to reverse. The connections between variables are called feedbacks and should be understood as the two-way connectors, either reinforcing (positive feedback) or dampening (negative feedback) system change.

Principle four: Foster complex adaptive systems thinking

A complex adaptive systems (CAS) approach means accepting unpredictability and uncertainty, and acknowledging a multitude of perspectives. In practice, this could, for example, mean keeping things dynamically fluctuating within specified boundaries rather than at fixed levels.

Principle five: Encourage learning

Coping with change or navigating transitions rely on constant learning and reevaluation of existing knowledge. Encouraging learning has to do both with knowledge itself and its distribution.

\section{Principle six: Broaden participation}

Broad and well-functioning participation is beneficial for several reasons. An informed and well-functioning group has the potential to create a shared understanding and build trust - both fundamentally important for collective action. 
Principle seven: Promote polycentric governance

Polycentricity, or when multiple governing bodies interact to make and enforce rules within a specific policy arena or location, is considered to be one of the best ways to achieve collective action. However, involving a wide range of actors means striking a balance between openness, accountability and mandates for decision-making.

This chapter should pay attention to increasing demand for biological raw materials in a bio-economy context (bioenergy, fibres and organic matter), climate change, food provisioning from land and water, and water availability. It should assess how the value of biodiversity and associated ecosystem services influences indirect drivers, and how the integration of such values into national and local development planning and accounting may help address Aichi Biodiversity Target 2, which links to Chapter 2 and 6 .

The chapter relates to the long-term 2050 vision of the Strategic Plan for Biodiversity of CBD and should help to identify possible pathways to achieve this vision. The chapter also needs to consider long-term visions in policy documents, such as the EU's biodiversity strategy to $2020^{40}$ and the strategies and policies of Nordic countries and regions. Scenarios employed may, however, need to cover much longer time spans than above, to be able to address the question of long-term sustainability. In forestry, for example, the rotation period is 70-100 years, and several rotations may be needed to evaluate sustainability. This chapter will gain from outputs of the thematic assessment on scenarios and models of biodiversity, ecosystem function and ecosystem services (IPBES deliverable 3 (c).

\section{Chapter 6: Options for governance, institutional arrangements and private and public decision-making across scales and sectors}

Informed by the analysis in previous chapters, Chapter 6 should reflect the conceptual framework boxes and fluxes on "Institutions and governance and other indirect drivers". Regarding IPBES related work, see Annex 7, Box 16. "Policy support tools and methodologies under IPBES". The chapter should look at options at temporal and spatial scales: from the international level to local and households. Explorations of options should be policy-relevant, but not be policy-prescriptive, as outlined under IPBES. The Assessment should focus on main interventions. 
The chapter should focus on what is specific to Nordic countries, e.g. what type of management regimes and governance systems are specific to the Nordic countries, for example, related to democracy and joint consultation, broader stakeholder consultations and other forms of public participation, citizens' panels and shared values.

The chapter needs to take into consideration policy and legal framework, such as EU biodiversity strategy to 2020,41 and the Nordic countries' national and regional policy and legal frameworks.

The assessment should analyse and possibly map options of policy mixes and alignments of polycentric governance (Ostrom, 2010; Biggs et al., 2015), and institutions - which are understood as formal and informal rules and norms that structure human interactions so as to reduce the uncertainties inherent in interactions (Ostrom, 1990, 2005) - at different scales. This includes the various rules and norms from international and regional agreements as well as government level to local customary norms, and different bodies of knowledge relevant to understanding and articulating biodiversity, biocultural relationships and ecosystem services. The chapter should include analysis of management options related to commons, i.e. ecosystem services and functions are part of the commons as public goods, and also assess responses in terms of collective action.

Special attention should be given to policy coherence, and to overlapping policy and legal frameworks and how these contradict or support each other. In particular contradictory sectoral policy issues should be highlighted.

The chapter should, with previous chapters in mind, analyse future challenges for sustainable use and conservation of biodiversity and ecosystem services. The chapter should assess options for integrating biodiversity and ecosystem services into sustainable development strategies and national accounting, and in key sectors in the Nordic region, such as agriculture, forestry, fisheries, water management, spatial planning, energy (including bioenergy), tourism and infrastructure.

Given the governance traditions of the Nordic countries, policy instruments such as fiscal reforms can be considered potentially strong and effective measures for the conservation and sustainable use of biodiversity. The chapter should include definitions, categorisation, mapping and analysis of different policy, legal and economic instruments and incentives, and market tools, such as labelling and green markets, phasing out subsidies harmful to biodiversity, and fiscal reforms in the form of green taxes, as well as payment for ecosystem services. It should assess the effectiveness of such options and consider who would gain or bear costs and what

${ }^{41}$ http://ec.europa.eu/environment/nature/biodiversity/comm2006/2020.htm 
safeguards need to be in place. Stakeholder mapping related to analysed governance and decision-making should be done and presented.

Options explored should include conservation, sustainable use and management practices. It should explore measures taken to achieve sustainable production and consumption of biodiversity, ecosystem function and ecosystem services. The chapter should include an analysis of customary sustainable use of biological diversity and its indirect effect on biodiversity, local livelihood and human well-being.

Learning, education and innovations, for managing and governing biodiversity and ecosystems, and capacity for recognising and navigate change should be analysed. The chapter should assess how to manage slow variables and feedbacks. An example of a slow variable is soil erosion, where time-diminished soil organic matter can result in lower productivity over time. The Nordic Assessment should include knowledge on historical ecology, natural resource management, and rural history should also be included when assessing governance options.

The chapter should also identify enabling environments and limitations for policy uptake and lessons learned, including solutions and methods for ensuring success, as well as capacity-building needs.

\section{Box 5. The ecosystem approach}

In applying the 12 principles of the ecosystem approach below, the following five points are proposed as operational guidance:

- 1. Focus on the functional relationships and processes within ecosystems.

- 2. Enhance benefit-sharing.

- 3. Use adaptive management practices.

- 4. Carry out management actions at the scale appropriate for the issue being addressed, with decentralisation to lowest level, as appropriate.

- 5. Ensure intersectoral cooperation.

The 12 principles of the ecosystem approach

Principle 1: The objectives of management of land, water and living resources are a matter of societal choice.

Principle 2: Management should be decentralised to the lowest appropriate level.

Principle 3: Ecosystem managers should consider the effects (actual or potential) of their activities on adjacent and other ecosystems. 
Principle 4: Recognising potential gains from management, there is usually a need to understand and manage the ecosystem in an economic context. Any such ecosystem-management programme should:

- Reduce those market distortions that adversely affect biological diversity.

- Align incentives to promote biodiversity conservation and sustainable use.

- Internalise costs and benefits in the given ecosystem to the extent feasible.

Principle 5: Conservation of ecosystem structure and functioning, in order to maintain ecosystem services, should be a priority target of the ecosystem approach.

Principle 6: Ecosystems must be managed within the limits of their functioning.

Principle 7: The ecosystem approach should be undertaken at the appropriate spatial and temporal scales.

Principle 8: Recognising the varying temporal scales and lag-effects that characterise ecosystem processes, objectives for ecosystem management should be set for the long term.

Principle 9: Management must recognise that change is inevitable.

Principle 10: The ecosystem approach should seek the appropriate balance between, and integration of, conservation and use of biological diversity.

Principle 11: The ecosystem approach should consider all forms of relevant information, including scientific and indigenous and local knowledge, innovations and practices.

Principle 12: The ecosystem approach should involve all relevant sectors of society and scientific disciplines.

Ref: http://www.cbd.int/ecosystem/

When analysing governance options, it is important to build on current information and developments under MEAs, such as CBD. It will address issues related to Goals A and E of the Strategic Plan for Biodiversity and the relevant Aichi Targets (in particular Aichi Targets 1, 2, 3,4, 17,18, 19 and 20) as well as Target 16, see Annex 8 Aichi Biodiversity Targets. One example of earlier developments that related to the potential Nordic Assessment is the Ecosystem Approach, see Box 5, which has been developed under CBD and supports a landscape and seascape perspective on ecosystem management. 


\subsection{Organisation}

\subsubsection{A. Strategic partnerships, initiatives and experts}

In accordance with the operating principles of IPBES, partnerships are important in order to avoid duplication while promoting synergies with on-going activities. Strategic partnerships and collaboration will help deliver the Nordic Assessment. They could provide scientific and technical support, datasets and reports, administrative support, capacity building, outreach and networking, experience in bridging science and policy, and experience or collaboration with holders of indigenous and local knowledge and their organisations. Strategic partnerships should be formal and informal, with attention paid to ensuring disciplinary and geographic balance. Among potential partners, the most valuable ones would be organisations with existing networks and multidisciplinary approaches.

Broad expertise and knowledge is needed to carry out the assessment, in terms of scientific disciplines, policy and practical competences, including from governance at various levels and regarding ILK. Strategic partnerships should also be established with institutions, organisations, societies, networks and associations working with, or representing ILK holders within the region, such as Sami Parliaments and Sami Councils, Inuit organisations, indigenous education institutions, local breed organisations, or allotment garden organisations as well as conservation NGOs.

During this planning phase of the Nordic Assessment process, possible strategic partners and initiatives have been identified that should be considered for the full Nordic Assessment, see Annex 4 Potential Strategic Partners and Roster of Experts. Nomination processes should take place when appropriate as explained under "Operational structure and Rules and procedures" section for the full assessment.

As described in the Scope Section, there is a need to find a focus for several sub-assessments with lead institutions, or hubs, to support the selected authors, that also contribute in finding financing for these separate parts of the assessment. See Annex 5 for suggestions.

IPBES has developed a stakeholder engagement strategy; see Annex 7, Box 8. The Nordic Assessment also needs to consider how stakeholders can and will be engaged in its work. The first step is to define what a stakeholder is and who they are. This links also to the communications and outreach strategy, see below. It is obvious from the IPBES strategy that scientists who participate as assessment co-chairs, authors and re- 
viewers are considered to be stakeholders. Their needs should be addressed, and potential incentives and disincentives identified. The list of potential stakeholders is, however, much longer, including, for example, holders of ILK.

\subsubsection{B. Communication and outreach}

IPBES has developed a communication and outreach strategy, see Annex 7, Box 9. The Nordic Assessment will need to develop a similar strategy adapted to the Nordic Assessment, both in order to promote the Nordic Assessment, but also to explain the larger IPBES context and overarching messages.

Early in the Nordic Assessment there is a need for audience analysis or stakeholder/actor mapping (this also relates to the stakeholder engagement strategy) partly to ensure the understanding of the whole target group of the assessment and their needs, but also because this is an important statement in itself - to have a picture of who the players and users in the Nordic context actually are. This is partly done in the Nordic ILK Scoping Study and the Nordic Introductory including Scoping Study at large, see Appendices, but it needs to be further developed concerning their needs and considered throughout the Nordic Assessment.

The general Nordic Assessment report, its summary and summaries for policymakers should be published in electronic format. The summary or summaries for policymakers should be available in all Nordic languages, including the main Sami languages, and kalaallisut (West Greenlandic), in printed format. However, the costs of translation will be subject to additional applications for funding. A Nordic Assessment website could be set up, where the reports could be available in electronic format. Outreach should be based on the IPBES Platform's communication and outreach strategy, adapted by the Secretariat for the Nordic Assessment to Nordic circumstances. The inclusive approach in the Stakeholder Engagement Strategy of the IPBES has the potential to guide the work of engaging civil society at large. Dissemination has the potential to target all relevant actors and be adapted to the specific interests of different users, and metadata used in the assessments could be made publicly available in accordance with relevant guidance developed by the IPBES. The Nordic Assessment can use similar approaches.

It is necessary for the Nordic Assessment to operate using existing formal and informal networks, and to work across scales. Communication and outreach should include capacity building on forming and sustaining networks if necessary. 
When working with and communicating the Nordic Assessment, it is important to use language and terminology under IPBES but for some issues adapted to a Nordic context. Terminology is presented in Annex 9 "Abbreviations and Glossary". However, this needs to be refined throughout the Nordic Assessment.

\subsubsection{Capacity building}

A key objective of all the regional assessments under IPBES is to build capacity to undertake assessments at the regional and subregional levels and to initiate a broader community capacity-building exercise that should continue after the assessment is complete, including, in particular, the strengthening of effective citizen science and contributions of ILK systems and their contribution in monitoring of assessments. For further information, see Annex 7, Box 10. "Capacity building under IPBES". The Nordic Assessment should address this in the assessment and could identify capacity building needs in the Nordic region.

It seems likely that most of the capacity building that needs to be identified by IPBES is relevant to the Nordic Assessment, not least concerning the capacity of policymakers and practitioners to use assessment findings in policy development and decision-making.

Capacity building with the aim to improve the capacity to undertake assessments has the potential to simultaneously build capacity to implement new policy formulated based on the results of assessment. To a large extent, the same actors should be involved, and structures or tools built to facilitate assessment activities could also be useful in the implementation stage. This potential should be realised as far as possible.

It is acknowledged that capacity building needs may vary widely within the region, and from country to country. It will therefore be necessary to carefully assess capacity-building needs, and promote and facilitate capacity-building activities that address those needs, for example to assess needs to improve access to data, information and knowledge that could help underpin assessment processes, and for increased experience in developing and using tools, such as scenarios and indicators. A general capacity building in society, and especially among decision-makers, regarding the links between local culture and practices, biodiversity management, ecosystem services and sustainable use is another important aspect. During implementation of the Nordic Assessment, it will be important to share experiences as widely as possible. This should be focused on both individuals and institutional capacity. 
The capacity building needed may benefit from the formation of new participatory processes, in which citizens, organisations, companies and other actors take an active part in the local, regional and national management of biodiversity and ecosystem services. Management practices should take into account the complex and often unpredictable nature of ecosystem processes, especially in the face of global change. Adaptive management with feedback loops would increase resilience. Platforms for transdisciplinary knowledge production, collaborative learning and mutual sharing of knowledge and experiences will be needed. Citizen science would engage wider participation in the monitoring and management of biodiversity.

If possible, the Nordic Assessment could aim to include young scientists in the Assessment expert groups as contributing authors. This has been done for the IPBES regional assessments with support from the IPBES Young Fellows Programme.

The Nordic Assessment should seek collaboration with the IPBES task force on capacity building and its technical support unit. The IPBES Technical Support Unit (TSU) for capacity building prioritised by the IPBES Plenary has been established in Trondheim, co-located with the Norwegian Environment Agency. Capacity building in ODA-eligible countries is the main target group, but the Nordic Assessment should seek to link up with them and look for synergies.

\subsubsection{Operational structure and Rules and procedures ${ }^{42}$}

The IPBES scoping reports for the regional assessments describe content matter that needs to be addressed in the Assessments, whereas the formal IPBES procedures for the preparation of platform deliverables, together with the clarifying guidance document, offer basic instruction on how to organise the work. These procedures stipulate how co-chairs, authors and reviewers are selected; what kinds of data sources can be used; how uncertainty is to be treated; how a full external review is achieved; how the draft report is first validated and then decided upon; and finally, how alleged errors are to be handled.

The Nordic Assessment is, formally speaking, not an IPBES activity, as it has not been initiated or mandated by the IPBES Plenary. There should, however, be very strong links to IPBES, as the Nordic Assessment is in-

\footnotetext{
42 This section includes texts from "The need for consistency with IPBES rules and procedures, by Torbjörn Ebenhard, CBM, 2015-09-03".
} 
tended to feed data, information and knowledge into formal IPBES assessments where relevant, such as the regional assessment for Europe and Central Asia, and the global assessment. There is also the potential to feed into the thematic IPBES assessments.

There are several conditions that need to be met for the Nordic Assessment to be successful in its attempt to feed into IPBES assessments. First, the general objectives and goals of the Nordic Assessment need to be in line with those of IPBES. One way of achieving this is to apply the IPBES conceptual framework, which is used in this project plan. Second, the data, analyses and scenarios used in the Nordic Assessment should be produced according to a process that follows the rules, procedures, and guidelines, employed by IPBES. Some of this guidance can be applied directly, but much has to be translated and scaled down to a Nordic context in a pragmatic manner.

The Generic Scoping Report for the IPBES Regional Assessments of Biodiversity and Ecosystem Services states that operational structures need to be identified that will best deliver the assessment, including related capacity building. Suggestions for operational structure of the Nordic Assessment and also rules of procedures are explained below.

The Nordic Assessment should link up with the TSU for the regional IPBES assessment for Europe and Central Asia, and should also take into account existing initiatives and organisations, such as the MAES working group, the European Environment Agency and the Pan-European Biodiversity Platform supported by the United Nations Environment Programme. The MAES initiative will be directly supported by ESMERALDA, a coordination support action funded under Horizon 2020, and indirectly by the knowledge generated in several European Union projects (such as OPERA and OpenNESS), funded under the seventh Framework Programme for Research and Technological Development (FP7), and by knowledge generated by European Union Horizon 2020 projects, including the European Research Area on biodiversity and ecosystem services (BiodivERsA 2 and 3), co-funded by the European Union and its Member States. The organisational structure will also need to help facilitate learning and cooperation.

The IPBES assessments are highly structured social processes for advancing the science-policy interface and are characterised by being credible, legitimate and relevant. To achieve these characteristics, an assessment has to go through the following phases: (1) the start-up scoping phase; (2) the assessment phase, consisting of the critical evaluation of the state of knowledge by selected experts including by synthesising for policy-makers the key findings and their confidence levels; and two rounds of peer review, 
one of which includes the review by policy makers; and (3) the end phase for approval of the policy relevant key findings. This project plan is aiming at to cover these main steps, see this Section D. Operational structures, rules and procedures, and E. Process and timetable, below.

The IPBES procedures describe the roles of several governance structures in the preparation of deliverables, most importantly the Plenary, the Bureau, and the Multidisciplinary Expert Panel. In a Nordic Assessment, these roles have been translated into a corresponding but simplified set of organisational bodies, see Box 6 below.

The IPBES Plenary consists of state member delegations. IPBES also has the more operative Bureau as one of its two subsidiary bodies. Since the Nordic countries do not have governance structures similar to the IPBES Plenary and Bureau, these functions are suggested here to be adapted to the possible circumstances in the Nordic context in a pragmatic manner.

For the Nordic Assessment the correspondence of the Plenary still has to be defined: Is it the Nordic governments, some sort of board selected by the Nordic governments, the Nordic Council of Ministers, or another entity at the Nordic regional level, that has the mandate to do this? For the potential assessment to be able to be in line with IPBES Rules of Procedure this has to be defined, i.e. the authorising environment that has to approve the scope, give a mandate for the assessment and finally accept the assessment report.

For the Nordic Assessment the corresponding body for the Bureau could be the Steering Committee consisting of, for example, IPBES national focal points from each of the Nordic countries, being selected by and representing their governments.

The roles of the MEP is suggested to correspond, in the Nordic Assessment, to an Expert Committee of scientists and other knowledge holders, selected by the Steering Committee following an open nomination process. The Expert Committee could consist of scientific and technical experts, as well as holders of ILK.

The Steering Committee and the Expert Committee should meet jointly, when possible, in the Nordic Assessment. The reason for that is that is both practical regarding time and for budget implications, but also that it might improve the possibility of strengthening the interface between policy, practice and science.

Two co-chairs to lead the Nordic Assessment process should be selected by the Expert Committee. After selection, they should be part of the Expert Committee.

For the Nordic Assessment, a Secretariat should be established with preferably one full-time equivalent professional position, in the present 
budget covered to $50 \%$ by the Nordic Council of Ministers, but another $50 \%$ would preferably be applied for or offered in-kind by Nordic governments.

Further, a Management Committee could be established, consisting of the two co-chairs, one representative from the Steering Committee selected by the Steering Committee, and the Director of the Secretariat.

The Expert Committee should, after a nomination and selection process that has to be at the level of individual experts, select co-chairs, coordinating lead authors, lead authors and review editors. A process should then take place to invite institutions to become hubs in support of authors. It is important to safeguard scientific merits and ensure a multidisciplinary and transdisciplinary author group, as well as the independence of scientific and other knowledge systems.

Box 6. Terminology for the organisational structure of the Nordic Assessment of Biodiversity and Ecosystem Services

For the Nordic Assessment the correspondence of the plenary, the authorising environment, still has to be defined: Is it the Nordic governments, some sort of board selected by the Nordic governments, the Nordic Council of Ministers or another entity at the Nordic regional level that has the mandate to do this?

Steering Committee - consisting of, for example, IPBES national focal points from each of the Nordic countries, representing and being selected by their governments, corresponding to the role of the IPBES bureau.

Expert Committee - that consists of scientists and other knowledge holders, based on nominations and approved by the Steering Committee, corresponding to the IPBES MEP.

Management group - consisting of the co-chairs and one representative from the Steering Committee, one from the Expert Committee, and the Director of the Secretariat.

Committee on Conflicts of Interest - consisting of three members of the Steering Committee and the Expert Committee.

Report co-chairs - They have responsibility for overseeing the preparation of the Nordic Assessment report.

Coordinating lead authors - To assume overall responsibility for coordinating major sections and/or chapters of the assessment report, (that could work in collaboration with Nordic hubs).

Lead authors - To assume responsibility for the production of designated sections or parts of chapters of the Nordic Assessment.

Contributing authors - To prepare technical information in the form of text, graphs or data for inclusion by the lead authors in the relevant section or part of a chapter. 
Review editors - To assist the Expert Committee in identifying reviewers for the expert review process, ensure that all substantive expert and government review comments are afforded appropriate consideration, advise lead authors on how to handle contentious or controversial issues and ensure that genuine controversies are adequately reflected in the text of the report concerned.

Expert reviewers -To comment on the accuracy and completeness of the scientific, technical and socioeconomic content and the overall balance between the scientific, technical and socioeconomic aspects of the drafts.

The Nordic hubs - could be groups or networks of scientists contributing to authors and different themes and parts of the assessment.

Citizens' panels or User groups - consist of representatives from public institutions, civil-society organizations, including organisations for holders of indigenous and local knowledge, and the private sector. Consultations with these groups can be in the form of dialogue seminars.

(The definitions here are elaborated and adapted from the document IPBES/3/18.)

Several Nordic hubs, to support authors, may be established and formed around different themes and parts of the Nordic Assessments in a consortium, or network with other Nordic institutions. The hubs would probably need to be self-financed, i.e. they would need to have on-going activities that could align with themes in the Nordic Assessment, or see opportunities to submit proposals for financing of such topics. The motivation for the hubs would be that they find the Nordic Assessment, and cooperation with Nordic institutions, valuable.

The Nordic Assessment could also draw upon citizen panels (user groups) - with representatives from public institutions, civil-society organisations, including organisations for holders of ILK, and private sector, to ensure legitimacy, credibility and usefulness. The groups would contribute to reviews mainly of the summary for decision makers, but also other parts of the assessment where appropriate.

The tasks and responsibilities of report co-chairs, coordinating lead authors, lead authors, review editors and government-designated national focal points for IPBES in general are outlined in Annex I of the procedures (Decision IPBES-3/3, Annex I). In Box 6 they have been adapted to the Nordic Assessment, in line with the above.

Experts (scientist or other knowledge holders) who wish to contribute material for consideration in the first draft should submit directly to the lead authors. Lead authors would work on the basis of these contributions, as well as the peer-reviewed and internationally available literature. 
The Co-chairs, in consultation with the coordinating lead authors and lead authors, should suggest early on in the assessment how results from potential sub-assessments fit into the chapter structure. The final structure will have to be presented and discussed with the Expert Committee.

Admission of observers to meetings: Observers, relevant to the assessment should be allowed when invited and when there is a need for them. The chair of each body should decide on a case-by-case basis, if there is no consensus on the admission of observers. In the operations of the Nordic Assessment experts should be invited to participate in relevant parts, in which case they are not observers. The Nordic Assessment should strive towards fostering an open and transparent working process.

Conflict of interest policy: Although not formally an IPBES assessment, the Nordic Assessment should apply the IPBES conflict of interest policy. For further information, see Annex 7. "Box 11. Conflict of interest policy under IPBES". The members of the established organisational bodies, see above, have to complete a conflict of interest form. Similarly, the report co-chairs and all coordinating lead authors, lead authors and review editors would have to go through the entire process. In order to be able to perform this, the Nordic Assessment also needs to establish its equivalent to the Committee on Conflicts of Interest. For the Nordic Assessment a Committee on Conflicts of Interest could consist of three members from the Steering Committee and the Expert Committee, as decided by the Steering Committee.

Procedures for the preparation of Platform deliverables. IPBES-3 adopted procedures for the preparation of Platform deliverables (Decision IPBES-3/3, Annex I). For further information, see Annex 7, "Box 12. IPBES Definitions related to organisation and rules of procedure". The procedures cover all different kinds of deliverables, such as assessment reports, synthesis reports, summaries for policymakers, technical papers and supporting material. The most relevant deliverables to conform to in a Nordic Assessment context would be assessment reports for subregional assessments, summaries for policy makers, and supporting material.

Preparation of the assessment report. For information on how this works under IPBES see Annex 7, "Box 13. Preparation of reports under IPBES". In preparing the first draft of a report and at subsequent stages of revision, lead authors should clearly identify disparate views for which there is significant scientific, technical or socioeconomic support, together with the relevant arguments. Sources of uncertainty should be clearly identified, listed and quantified where possible. The implications for decision-making on the findings, including knowledge gaps, contrasting evidence and minority opinions, should be explicitly discussed. 
The Nordic Assessment report and its summary for policymakers should be subject to an independent review process. The process should be coordinated by selected review editors, as decided by the Expert Committee, and should involve independent expert reviewers, as well as representatives from the governments. Three principles govern the review process: first, the report should represent the best possible scientific, technical and socioeconomic advice, and be as balanced and comprehensive as possible; second, as many experts as possible should be involved in the review process, ensuring representation of independent experts (i.e., experts not involved in the preparation of the chapters they are to review) from all Nordic countries; third, the review process should be balanced, open and transparent, and record the response for each review comment.

The Nordic Assessment report and the summary for policymakers should be validated by the Steering and Expert Committees. Validation is a process to provide endorsement that the processes for the preparation of the report and its parts have been duly followed. The Nordic Assessment of report should be accepted by the Steering Committee. It should also be accepted by the authorising entity that is not yet defined for the Nordic Assessment. Acceptance of a report signifies that the material has not been subjected to section-by-section or line-by-line discussion and agreement, but nevertheless presents a comprehensive and balanced view of the subject matter. The summary for policy makers should be approved by the Steering Committee. Approval signifies that the material has been subject to detailed, line-by-line discussion and agreement by consensus.

The review processes should ensure that errors are eliminated well before the publication of the Nordic Assessment report. However, if a reader should report an error (e.g., a miscalculation or a factual inaccuracy) in an accepted report chapter or approved summary for policymakers, the issue should be brought to the attention of the Secretariat, which should implement a process for error correction.

Procedure on the use of literature in the reports of the Platform: IPBES-3 adopted a procedure on the use of literature, as part of the procedures for the preparation of Platform deliverables (Decision IPBES-3/3, Annex I, Appendix II). The text below is adapted from the IPBES procedure for the Nordic Assessment. 
Priority should be given to peer-reviewed and publicly available literature, but it is also recognised that other sources provide crucial information, such as, reports by governments, industry and research institutions, international and other organisations, or conference proceedings (often referred to as "grey literature"). The use of such diverse sources, however, brings with it an extra responsibility for the author teams in ensuring the quality and validity of cited sources and information. In general, newspapers and magazines, blogs, social networking sites and broadcast media are not acceptable sources of information for the reports. Personal communications providing scientific results are also not acceptable sources.

Unpublished material, and outputs deriving from indigenous and local knowledge, may be used in assessments, provided that their unpublished status is specified. Such materials will need to be made available for the review process and their sources identified in the report to ensure that appropriate knowledge and data safeguards are in place. As stated in the IPBES Data and Information Management Plan, there is a need to recognise the interests of custodians of data and knowledge, such as access rights and intellectual property rights, in particular the need to respect information provided by and the knowledge of indigenous peoples and local communities, which includes, as appropriate, consideration of seeking prior informed consent or approval and the involvement of indigenous peoples and local communities, who are holders of such information and knowledge, and the sharing of benefits accrued from such information and knowledge.

For sources that are not publicly available, the coordinating lead authors responsible for the coordination of the report chapters or sub-assessments should make these sources available to reviewers who request them during the review process and send the material to the Nordic Assessment Secretariat for archiving. Access to these materials should be permissible on request. Storage procedures should comply with protocols and guidelines to be agreed under the Nordic IPBES Data and Information Management Plan (see Annex 7, Box 3). The Nordic Assessment would have to be able to provide the IPBES regional assessment expert groups, and expert reviewers with all sources not publicly available that are used in the Nordic Assessment report. 


\subsubsection{E. Process and timetable}

The Nordic Assessment should preferably feed into the IPBES regional assessment on biodiversity and ecosystem services for Europe and Central Asia. The proposed process for undertaking the IPBES regional assessments and the timetable are outlined in Annex 7, "Box 14. Process and timetable for regional and subregional assessments, work plan as agreed in the IPBES".

Below in Table 4 is a suggested process and timetable for the Nordic Assessment. 
The Introductory study including scoping for a Nordic Assessment takes place, financed by the Nordic Council of Ministers. An ILK study integrated with the full Scoping study has been performed by NAPTEK

Indigenous and Local Knowledge: It is essential to keep a continuous dialogue with ILK holders, on their own terms. The assignment to NAPTEK at CBM regarding an inclusive process for Indigenous and Loca Knowledge in the Scoping Study for the Nordic Assessment of Biodiversity and Ecosystem Services, included development of methods for how this could be done in practice, in dialogue with ILK representatives and the ILK task force under IPBES, and the Nordic project group for the scoping study, to be ready for the final version of the assignment for the Full Nordic Assessment. Preliminary, the following procedure could be included during 2016 to have one initial Nordic practical workshop and 4-8 dialogue workshops covering diverse knowledge systems connecting holders of knowledge in a suitable manner related to geographic relevant areas and language. The smaller dialogue workshops could be followed by a larger Nordic workshop to consolidate the results. Also, it could be useful to prepare one or more ILK questionnaires in the national languages, for the purpose of preparing ILK background information for the chapters of the Nordic Assessment (i.e. in order to make non-published ILK reflections available for the Nordic Assessment). This IK assessment will have to be closely linked to the Nordic Assessment of Biodiversity and Ecosystem Services. The financing of the ILK assessment is not included here, but could form a hub and sub-assessment.

If the basic funds are secured for a full Nordic Assessment, the secretariat, Steering Committee and Expert Committee should be established. The Expert Committee could take the lead in discussions regardin developing a more detailed organisation plan for the assessment, i.e. potential focus of different sub-assessments and how they could contribute to full assessment and fit into the chapter structure.

Invite nominations for co-chairs, coordinating lead authors, lead authors (including ILK holders) and review editors (including ILK holders) for the Nordic Assessment. Possible channels for disseminating information about the nomination process are through invitation letters and Nordic countries' nodal websites. The list developed in the appendices of potential strategic partners, roster of experts and Nordic hubs developed in the Scoping may be of assistance here. Methods developed under the ILK Scoping Study on how to work with ILK in the Nordic Assessment should be applied throughout the process.

\section{Secretariat compiles lists of nominations.}

The Expert Committee selects co-chairs, coordinating lead authors, lead authors (including ILK holders) and review editors (including ILK holders) for the Nordic Assessment. They then invite institutions to become hubs for sub-assessments.

Second quarter Selected nominees contacted, gaps filled, and list of co-chairs, coordinating lead authors, lead authors and review editors finalised, including a meeting of the expert committee to finalise selection and allocation of coordinating lead authors, lead authors and review editors for each of the chapters/sections in the Nordic Assessment.

Authors' (coordinating lead authors and lead authors) meetings to discuss the annotated outlines of the assessment chapters and finalise author (contributing author) assignments for the Nordic Assessment together with the Expert Committee. The co-chairs are members of the Expert Committee. Representatives from the regional assessment for Europe and Central Asia should be informed and involved as far as possible.

First drafts of the sub assessments and the chapters prepared for the Nordic Assessment by the co-chairs, and sent for consultation to all coordinating lead authors, the Expert Committee and the Steering Committee. The draft should also be sent for consultation to the regional assessment for Europe and Central Asia, and if relevant to other IPBES expert groups and task forces. Comments should be gathered by the secretariat and hubs responsible for different sub-assessments to feed into the first draft of the Nordic Assessment.

A "stocktaking milestone" in October 2016, to take stock of resources and make necessary adjustments to the project plan, is suggested, to understand and evaluate how operational the project plan is and to report this to donors. This should be done preferably by the management group. 
First draft of Nordic Assessment sent for review to expert reviewers (including ILK holders).

Collation of review comments by the Secretariat. The collated comments should be sent to the co-chairs and hubs/coordinating lead authors.

Second drafts of chapters and first drafts of summary/summaries for policymakers prepared for Nordic Assessment.

Second quarter Authors' meetings (co-chairs, coordinating lead authors and review editors) to finalise second draft of a Nordic Assessment.

Compilation of chapters into second draft Nordic Assessment with sections as appropriate, and associated first draft of the summary/summaries for policymakers.

Second draft of Nordic Assessment, and first draft of the summary/summaries for policymakers, sent for government and expert review including ILK holders. Consultations could also be held with citizen panels/user groups, either through the review process or in dialogues (on-line or if resources permit in seminars). The draft should also be sent for review to representatives of the subregional assessment for Europe and Central Asia, and to IPBES expert groups and task forces, and possibly Technical Support Units (TSUs).

Collation of review comments by the secretariat on the second draft of Nordic Assessment, and first draft of summary/summaries for policymakers. The collated comments should be sent to the co-chairs and the coordinating lead authors.

Third quarter

Authors' meetings (including review editors), to finalise the Nordic Assessment and summary/summaries for policymakers based on comments received from government and expert reviews (including citize panels or user groups). Representatives from the sub-regional assessment for Europe and Central Asia, should be invited. ILK holders is included in the processes above, they can be part of author teams, review editors or citizens panels.

Final text changes made to the Nordic Assessment and summary/summaries for policymakers.

Translation of summary/summaries for policymakers into main Nordic languages including indigenous peoples' languages, if budget permits.

Fourth quarter Submission of Nordic Assessment report, including the translated summary/summaries for policymakers, to the Steering Committee. The Nordic governments are represented through the Steering Committee.

Final Steering Committee comments on the summary/summaries for policymakers for consideration by the co-chairs.

The Nordic Assessment report and the summary for policy makers should be validated by the Steering and Expert Committees.

The Nordic Assessment report should be accepted by the Steering Committee, and potentially the correspondence of the IPBES Plenary (not yet defined).

The summary for policymakers should be approved by the Steering Committee.

The accepted Nordic Assessment report, including the translated and approved summary/summaries for policymakers, should be disseminated to Nordic governments, universities and other relevan knowledge institutions including ILK holders' organisations. The English versions of the assessment and summaries for policymakers should be sent to the expert group for the IPBES regional assessment Europe and Central Asia, and IPBES at large. 


\subsection{Budget}

The table in Annex 7, Box 15, shows the estimated cost of conducting and preparing the assessment report in one IPBES region.

The full Nordic Assessment will have its own budget but should aim to feed into the IPBES regional assessment on biodiversity and ecosystem services for Europe and Central Asia, and finally the global IPBES assessment. See below in Table 5. Note that the budget for the Nordic Assessment covers only very basic needs. In addition, there is a need for a budget to cover much of the co-chairs' hours of work, and some meeting costs and DSA. The assessment will, as the budget is presented in this document, include large amounts of in-kind contributions. The lack of funds presents a large risk factor to the fulfilment of the project plan. The Nordic hubs in support of authors should apply for funds for all sub-parts of the assessment, but there are no guarantees as to how successful they will be, nor is it yet clear if the project will be able to establish such hubs.

Table 5: Budget of the Nordic Assessment of Biodiversity and Ecosystem Services. As applied for to the Nordic Council of ministers, the budget counts on large in-kind contributions

\begin{tabular}{|c|c|c|c|}
\hline Year & Cost item & Assumptions & Cost (DKK) \\
\hline \multirow[t]{7}{*}{2016} & $\begin{array}{l}\text { Steering Committee meetings and Ex- } \\
\text { pert Committee meetings (if possible a } \\
\text { physical meeting, otherwise meetings } \\
\text { via telephone conference). }\end{array}$ & Meeting costs (in-kind contribution) & 0 \\
\hline & & Travel costs (DSA in-kind contribution) & 20,000 \\
\hline & $\begin{array}{l}\text { Management Group meetings } \\
\text { ( } 2 \text { co-chairs, } 1 \text { steering committee } \\
\text { member and } 1 \text { expert committee } \\
\text { member) (possibly one physical meet- } \\
\text { ing if available funds, other meetings } \\
\text { via telephone conference) }\end{array}$ & Meeting costs (in-kind contributions) & 0 \\
\hline & & Travel costs (DSA in-kind contribution) & 10,000 \\
\hline & $\begin{array}{l}\text { Authors' meetings (co-chairs, coordi- } \\
\text { nating lead authors and authors) at } \\
\text { least one physical meeting, other } \\
\text { meetings via telephone conference }\end{array}$ & $\begin{array}{l}\text { Meeting costs, in-kind and included in } \\
\text { separate hub proposals }\end{array}$ & 0 \\
\hline & & Travel costs (DSA in-kind contribution) & 20,000 \\
\hline & Technical support (Secretariat) & $\begin{array}{l}50 \% \text { of } 1 \text { full-time equivalent profes- } \\
\text { sional positions (possibly } 50 \% \text { in-kind) }\end{array}$ & 450,000 \\
\hline
\end{tabular}




\begin{tabular}{|c|c|c|c|}
\hline Year & Cost item & Assumptions & Cost (DKK) \\
\hline \multirow[t]{7}{*}{2017} & $\begin{array}{l}\text { Steering Committee meetings and Ex- } \\
\text { pert Committee meetings (if possible a } \\
\text { physical meeting, otherwise meetings } \\
\text { via telephone conference). }\end{array}$ & Meeting costs (in-kind contribution) & 0 \\
\hline & & Travel costs (DSA in-kind contribution) & 20,000 \\
\hline & $\begin{array}{l}\text { Management Group meetings } \\
\text { ( } 2 \text { co-chairs, } 1 \text { Steering Committee } \\
\text { member and } 1 \text { Expert Committee } \\
\text { member) (possibly one physical meet- } \\
\text { ing if available funds, other meetings } \\
\text { via telephone conference) }\end{array}$ & Meeting costs (in-kind contributions) & 0 \\
\hline & & Travel costs (DSA in-kind contribution) & 10,000 \\
\hline & $\begin{array}{l}\text { Authors' meetings (co-chairs, coordi- } \\
\text { nating lead authors and authors) at } \\
\text { least one physical meeting, other } \\
\text { meetings via telephone conference }\end{array}$ & $\begin{array}{l}\text { Meeting costs, in-kind and included in } \\
\text { separate hub proposals }\end{array}$ & 0 \\
\hline & & Travel costs (DSA in-kind contribution) & 20,000 \\
\hline & Technical support (Secretariat) & $\begin{array}{l}50 \% \text { of } 1 \text { full-time equivalent profes- } \\
\text { sional positions (possibly } 50 \% \text { in-kind) }\end{array}$ & 455,000 \\
\hline \multirow[t]{2}{*}{2018} & $\begin{array}{l}\text { Co-chairs' and the director/coordina- } \\
\text { tors participation in the fifth session of } \\
\text { the IPBES Plenary }\end{array}$ & $\begin{array}{l}\text { Travel and DSA (including in-kind con- } \\
\text { tributions) }\end{array}$ & 50,000 \\
\hline & $\begin{array}{l}\text { Dissemination and regional outreach } \\
\text { (summary for policymakers }(3 \times 10 \\
\text { pages) and report ( } 200 \text { pages }))\end{array}$ & $\begin{array}{l}\text { Translation of summaries for policy- } \\
\text { makers into all Nordic languages, } \\
\text { publication and outreach, + possibly } \\
\text { in-kind contributions from Nordic } \\
\text { countries }\end{array}$ & 50,000 \\
\hline Total & & $\begin{array}{l}\text { Note that this budget covers only very } \\
\text { basic needs. There is also a need for } \\
\text { funds to cover the co-chairs' hours of } \\
\text { work, and the meeting costs and DSA. } \\
\text { If performed, the assessment includes } \\
\text { large amounts in in-kind contributions. } \\
\text { The suggested Nordic hubs, supporting } \\
\text { authors, could apply for funds for sub- } \\
\text { parts of the assessment. }\end{array}$ & $1,105,000$ \\
\hline
\end{tabular}

For the IPBES assessments in general, there is not full cost recovery for those involved, as the assessments rely on substantial in-kind contributions from researchers and other knowledge holders, especially for experts from the non-(ODA)-eligible countries. There is usually a certain level of in-kind contributions in an assessment budget; however, a certain balance is needed to be able to secure the necessary regional and disciplinary balance. If the Nordic governments would like to have full involvement and time investment from the scientific community and other knowledge holders, substantial contributions to the budget are necessary. 
However, as this does not seem realistic at this point, the budget for the Nordic Assessment of Biodiversity and Ecosystem Services is dealt with in a pragmatic manner. The suggested budget for the Nordic Assessment of Biodiversity and Ecosystem Services implies that $50 \%$ of the costs for one full-time equivalent position is applied for from the Nordic Council of Minsters, and that $50 \%$ is received in-kind from Nordic governments. Furthermore, travel and meeting costs have to be covered by applications or in-kind support from Nordic governments. This budget also implies that each Nordic hub applies for research funds, or other funds, to cover their actual costs.

The ILK component in the Nordic Assessment, including the suggested method for linking different knowledge systems, is not covered in this budget estimate. Since ILK holders in many cases are self-employed, reimbursement for loss of income and other costs when participating should be included in a budget to secure their participation. This also pertains to scientists. If ILK holders are part of the author team, they are included at the same level as all experts or knowledge holders.

\subsection{Risk assessment}

The Nordic Assessment should be sufficiently focused on what is relevant in a Nordic context, and also be able to deliver the full assessment, and possible sub-assessments, in time to feed into the IPBES regional assessment and global assessment process.

The Nordic Assessment should contribute to decision-making that leads to positive changes for biodiversity, ecosystem services and human well-being. In order to do this, the assessment must be of relevance to policymakers and other relevant stakeholders. To meet these risks, the Nordic Assessment should find a focus and a manner of communicating results that are easy to access and of Nordic importance, such as interests related to: common resource use; similar governance structures; and shared cultural and behavioural aspects. The Nordic Assessment could also form a citizen panel or user group to validate results, which contribute to transparency, and effective use of the material.

The cost estimate is another risk element, and a very central one. The true and actual costs of the assessment, as presented in the project plan, go substantially beyond the presented budget, which is only based on possible funds from the Nordic Council of Ministers. This aspect is one of the major omissions from all IPBES work, and the consequences of relying on 
"in-kind" support from those actually ensuring the quality of the assessments are not adequately considered. This project plan for the Nordic Assessment suggests that each Nordic hub applies for funds for part of the assessment, to support the authors. This structure might not be attractive to many researchers and other knowledge holders. It is also suggested that individual governments in the Nordic countries could cover some of the in-kind costs for the Secretariat, and meeting and travel costs. The Secretariat is also encouraged to look for funds to cover meetings and travel costs, see Annex 6 for funding sources.

The question of funding is truly a challenge that needs to be addressed. The structure described in the project plan might be unrealistic when it comes to attracting possible interest from science and other knowledge holders, and also in terms of safeguarding the quality of the work performed.

Another risk is that the assessment might be a source of conflict, since national interests may differ.

A "stocktaking milestone" in October 2016, to take stock of resources and make necessary adjustments to the project plan, is suggested to understand and evaluate how operational the project plan is, and to report this to donors. This should be preferably be done by the Management Group. 



\section{References}

Ash, N., Blanco, H., \& Brown, C. (2010). Ecosystems and human well-being: a manual for assessment practitioners. Island Press.

Baumgärtner, S., \& Strunz, S. (2014). The economic insurance value of ecosystem resilience. Ecological Economics, 101,21-32. http://dx.doi.org/10.1016/ j.ecolecon.2014.02.012

Berkes, F. (1993). Traditional ecological knowledge in perspective. In Traditional Ecological Knowledge: Concepts and Cases, J. T. Inglis (ed.). Ottawa: International Program on Traditional Ecological Knowledge and International Development Research Centre. Pp 1-9.

Berkes, F., \& Folke, C. (2002). Back to the future: ecosystem dynamics and local knowledge. Panarchy: Understanding Transformations in Human and Natural Systems, 121-146.

Biggs, R., Schlüter, M., Biggs, D., Bohensky, E. L., BurnSilver, S., Cundill, G., ... Kotschy, K. (2012). Toward principles for enhancing the resilience of ecosystem services. Annual Review of Environment and Resources, 37, 421-448. http://dx.doi.org/10.1146/annurev-environ-051211-123836

Biggs, R., Schlüter, M., \& Schoon, M. L. (2015). Principles for Building Resilience: Sustaining Ecosystem Services in Social-Ecological Systems. (R. Biggs, M. Schlüter, \& M. L. Schoon, Eds.). Cambridge: Cambridge University Press. http://dx.doi.org/10.1017/CB09781316014240

CAFF. (2015a). Actions for Arctic biodiversity: implementation of the Arctic Biodiversity Assessment recommendations 2013-2021.

CAFF. (2015b). The Economics of Ecosystems and Biodiversity (TEEB) Scoping Study for the Arctic. Executive Summary. Conservation of Arctic Flora and Fauna, Akureyri.

CAFF 2013a. (2013). Arctic Biodiversity Assessment. Status and trends in Arctic biodiversity. Conservation of Arctic Flora and Fauna, Akureyri. Cited February.

CAFF 2013b. (2013). Arctic biodiversity assessment: report for policy makers, Conservation of Arctic Flora and Fauna, Akureyri.

Chambers, R. (1997). Whose reality counts?: putting the first last. Intermediate Technology Publications Ltd (ITP). http://dx.doi.org/10.3362/9781780440453

De Groot, R. S., Alkemade, R., Braat, L., Hein, L., \& Willemen, L. (2010). Challenges in integrating the concept of ecosystem services and values in landscape planning, management and decision making. Ecological Complexity, 7(3), 260-272. http://dx.doi.org/10.1016/j.ecocom.2009.10.006

Díaz, S., Demissew, S., Carabias, J., Joly, C., Lonsdale, M., Ash, N., ... Baldi, A. (2015). The IPBES Conceptual Framework-connecting nature and people. Current Opinion in Environmental Sustainability, 14,1-16. http://dx.doi.org/10.1016/ j.cosust.2014.11.002

Enfors, E. (2013). Social-ecological traps and transformations in dryland agroecosystems: using water system innovations to change the trajectory of development. Global Environmental Change, 23(1), 51-60.

http://dx.doi.org/10.1016/j.gloenvcha.2012.10.007 
Farber, S. C., Costanza, R., \& Wilson, M. A. (2002). Economic and ecological concepts for valuing ecosystem services. Ecological Economics, 41(3), 375-392.

http://dx.doi.org/10.1016/S0921-8009(02)00088-5

Foley, J. A., DeFries, R., Asner, G. P., Barford, C., Bonan, G., Carpenter, S. R., ... Gibbs, H. K. (2005). Global consequences of land use. Science, 309(5734), 570-574. http://dx.doi.org/10.1126/science.1111772

Folke, C. (2006). Resilience: the emergence of a perspective for social-ecological systems analyses. Global Environmental Change 16(3):253-267. http://dx.doi.org/10.1016/j.gloenvcha.2006.04.002

Folke, C., Jansson, ̊̊., Rockström, J., Olsson, P., Carpenter, S. R., Chapin III, F. S., ... Ebbesson, J. (2011). Reconnecting to the biosphere. Ambio, 40(7), 719-738. http://dx.doi.org/10.1007/s13280-011-0184-y

Gómez-Baggethun, E., Barton, D., Berry, P., Dunford, R., Harrison, P. (2016). Concepts and methods in ecosystem services valuation. In: Potschin, M., Haines-Young, R., Fish, R. and Turner, R.K. (eds.) Routledge Handbook of Ecosystem Services. Routledge, York,. London and New York.

Gunderson, L. H., and C. S. Holling. (2002). Panarchy: understanding transformations in human and natural systems. Island, Washington, D.C., USA.

Holling, C. S. (1986). The resilience of terrestrial ecosystems: local surprise and global change. Pages 292-317 in W. C. Clark and R. E. Munn, editors. Sustainable development of the biosphere. Cambridge University Press, Cambridge, UK.

Huitric, M., Walker, B., Moberg, F., Österblom, H., Sandin, L., Grandin, U., ... Bodegård, J. (2009). Biodiversity, Ecosystem Services and Resilience - Governance for a Future with Global Changes. Background report for the scientific workshop Biodiversity, ecosystem services and governance - targets beyond 2010, Tjärnö, Sweden, 4-6 September 2009. (M. Huitric, Ed.). Stockholm: Albaeco. Retrieved from http://www.stockholmresilience.org/21/publications/artiklar/3-19-2010biodiversity-ecosystem-services-and-resilience---governance-for-a-future-withglobal-changes.html

Jäppinen, J.-P., \& Heliölä, J. (2015). Towards A Sustainable and Genuinely Green Economy. The value and social significance of ecosystem services in Finland (TEEB for Finland).

Kettunen, M., \&, Vihervaara, P., Kinnunen, S., D’Amato, D., Badura, T., Argimon, M. and ten Brink, P. (2013). Socio -economic importance of ecosystem services in the Nordic Countries -Synthesis in the context of The Economics of Ecosystems and Biodiversity (TEEB),Summary for policy makers. Copenhagen. http://dx.doi.org/10.6027/TN2012-559

Kettunen, M., Vihervaara, P., Kinnunen, S., D’Amato, D., Badura, T., Argimon, M., \& Ten Brink, P. (2012). Socio-economic importance of ecosystem services in the Nordic Countries. Nordic Council of Ministers.

Maffi, L. (2010). What is biocultural diversity? In L. Maffi \& E. Woodley (Eds.), Biocultural diversity conservation: A global sourcebook. London: Earthscan.

Millennium Ecosystem Assessment (MA). (2005). Ecosystems and Human Well-being: Synthesis. Washington, DC: Island Press. Retrieved from http://www.millenniumassessment.org/documents/document.356.aspx.pdf

Nordic Council of Ministers. (2014). Nordic Statistical Yearbook 2014. Copenhagen.

Olson, M. (1971). The logic of collective action: Public goods and the theory of groups, revised edition. Cambridge: Harvard University Press.[1965,

Ostrom, E. (2005). Understanding institutional diversity. Princeton, NJ: Princeton University Press. 
Ostrom, E. (2010). Beyond markets and states: polycentric governance of complex economic systems. The American Economic Review, 641-672. http://dx.doi.org/10.1257/aer.100.3.641

Preston, C. J. (2003). Grounding knowledge: Environmental philosophy, epistemology, and place. University of Georgia Press.

Raworth, K. (2012). A safe and just space for humanity: can we live within the doughnut. Oxfam Policy and Practice: Climate Change and Resilience, 8(1), 1-26. Retrieved from https://www.oxfam.org/sites/www.oxfam.org/ files/file_attachments/dp-a-safe-and-just-space-for-humanity-130212-en_5.pdf

Rockström, J., Steffen, W., Noone, K., Persson, Å., Chapin, F. S., Lambin, E., ... Foley, J. (2009). Planetary boundaries: Exploring the safe operating space for humanity. Ecology and Society, 14(2).

Schultz, M. (2013). Making the value of ecosystem services visible - Proposals to enhance well-being through biodiversity and ecosystem services, Summary of SOU 2013:68. Stockholm.

Secretariat of the Convention on Biological Diversity. (2010). Global Biodiversity Outlook 3. Montréal.

Secretariat of the Convention on Biological Diversity. (2014). Global Biodiversity Outlook 4. Montréal.

Skidmore, A. K., Pettorelli, N., Coops, N. C., Geller, G. N., Hansen, M., Lucas, R., ... Pereira, H. M. (2015). Environmental science: agree on biodiversity metrics to track from space - Comment. Nature, 523, 403-405. http://dx.doi.org/10.1038/523403a

Steffen, W., Grinevald, J., Crutzen, P., \& McNeill, J. (2011). The Anthropocene: conceptual and historical perspectives. Philosophical Transactions of the Royal Society of London A: Mathematical, Physical and Engineering Sciences, 369(1938), 842-867. http://dx.doi.org/10.1098/rsta.2010.0327

Steffen, W., Richardson, K., Rockstrom, J., Cornell, S. E., Fetzer, I., Bennett, E. M., ... Sorlin, S. (2015). Planetary boundaries: Guiding human development on a changing planet. Science, 347(6223), 1259855-. Retrieved from http://dx.doi.org/10.1126/ science.1259855

Tengö, M., Brondizio, E. S., Elmqvist, T., Malmer, P., \& Spierenburg, M. (2014). Connecting diverse knowledge systems for enhanced ecosystem governance: the multiple evidence base approach. Ambio, 43(5), 579-591. Retrieved from http://dx.doi.org/10.1007/s13280-014-0501-3

Tunón, H., Kvarnström, M., \& Malmer, P. (2015). Report from the project: Indigenous and Local Knowledge in Scoping Study for the Nordic IPBES Assessment CBM:s skriftserie 96. Uppsala.

Turner, R. K., Paavola, J., Cooper, P., Farber, S., Jessamy, V., \& Georgiou, S. (2003). Valuing nature: lessons learned and future research directions. Ecological Economics, 46(3), 493-510. http://dx.doi.org/10.1016/S0921-8009(03)00189-7

United Nations. (2015). The 2030 Agenda for Sustainable Development, A/RES/70/1. Retrieved from https://sustainabledevelopment.un.org/post2015/ transformingourworld/publication

Vihervaara, P., Mononen, L., Auvinen, A.-P., Virkkala, R., Lü, Y., Pippuri, I., ... Valkama, J. (2015). How to integrate remotely sensed data and biodiversity for ecosystem assessments at landscape scale. Landscape Ecology, 30(3), 501-516. http://dx.doi.org/10.1007/s10980-014-0137-5

Walker, B., \& Salt, D. (2012). Resilience practice: building capacity to absorb disturbance and maintain function. Island Press. http://dx.doi.org/10.5822/978-161091-231-0 



\title{
Sammanfattning
}

\author{
Bakgrund
}

Agenda 2030 för en hållbar utveckling poängterar att utarmning av naturresurser och negativa effekter från miljöförstöring - inklusive förlust av biologisk mångfald - förvärrar de utmaningar som mänskligheten står inför. Biologisk mångfald är tydligt i de globala målen, inte bara i mål 15 för ekosystem och biologisk mångfald och mål 14 om hav och marina resurser, utan integrerat i alla 17 mål och 169 delmål. I Agenda 2030 betonas att den biologiska mångfalden är grundläggande för människors välbefinnande. (UN, 2015)

Utrotningshotade arter kommer i genomsnitt allt närmare utrotning, enligt Global Biodiversity Outlook 3 (CBD 2010). Nästan en fjärdedel av alla växtarter bedöms vara utrotningshotade. Den genetiska variationen hos grödor och boskap fortsätter att minska i jordbrukssystemen, liksom traditionell kunskap, innovationer och sedvänjor kopplade till biologisk mångfald och ekosystemtjänster. (CBD, 2010); (CBD, 2014)

För att möta dessa utmaningar behöver beslutsfattare trovärdig och oberoende information som tar hänsyn till de komplexa samband som finns mellan biologisk mångfald, ekosystemtjänster och människor. Som en respons grundades år 2012 the Intergovernmental Science-Policy Platform on Biodiversity and Ecosystem Services (IPBES), en global plattform för biologisk mångfald och ekosystemtjänster vars syfte är att bedöma tillståndet för planetens biologiska mångfald, dess ekosystem och de viktiga tjänster de tillhandahåller för människors välbefinnande, samt att ta fram kunskap om dessa frågor som underlag för beslutsfattare runt om i världen. IPBES är ett oberoende mellanstatligt organ som är öppet för alla medlemsländer i FN. Både det vetenskapliga och det politiska samfundet erkänner den mekanism plattformen erbjuder: att sammanfatta, granska, bedöma och utvärdera den information och kunskap som alstras över hela världen av förvaltningar, forskare, vetenskapliga organisationer, icke-statliga organisationer, urbefolkningar och lokala samhällen.

År 2014 beslutade de nordiska länderna att initiera en nordisk bedömning av biologisk mångfald och ekosystemtjänster baserad på IPBES metoder och riktlinjer. Bästa sättet att förbereda en sådan studie bedömdes vara att genomföra en grundlig förstudie. Naturvårdsverket i Sverige 
utarbetade en ansökan om finansiering från Nordiska ministerrådet, som beviljade 450000 DKK till projektet. Projektgruppen bestod av en grupp med representanter från de nordiska länderna, som valts av varje nordiskt lands myndigheter. Samråd skedde genom två frågeformulär, ett samnordiskt möte och löpande diskussioner i respektive land. I samband med den här förstudien genomfördes också en studie kring traditionell och lokal kunskap på uppdrag av Naturvårdsverket. Utförare var Nationellt program för lokal och traditionell kunskap relaterad till bevarande och hållbart nyttjande av biologisk mångfald (Naptek) vid Centrum för Biologisk Mångfald (CBM), Sverige. Uppdraget resulterade i publikationen "Report from the project: Indigenous and Local Knowledge in a Scoping Study for a Nordic IPBES Assessment." (Tunón et al., 2015)

Den här rapporten är ett resultat av förstudien. Den är uppdelad i två avsnitt: Sektion I som innehåller en beskrivning av process och metod samt en diskussion, och Sektion 2 som omfattar den inledande studien och ett förslag till projektplan för en fullständig nordisk bedömning av biologisk mångfald och ekosystemtjänster baserad på IPBES metoder och riktlinjer. Det här projektet har utvecklat en metod för hur en studie kan planeras och genomföras i ett underregionalt sammanhang som till exempel de nordiska länderna utgör. Aktörer som potentiellt kan bidra till en fullständig bedömning har identifierats, liksom källor och brister i data och kunskap, samt nyckelfrågor för en fullständig nordisk bedömning. Den här rapporten är en förkortad version som publiceras som en TemaNord-rapport. Hela arbetsdokument kan nås via Naturvårdsverket $\mathrm{i}$ Sverige eller projektledaren Maria Schultz vid Stockholm Resilience Centre.

\section{Omfattning, geografisk avgränsning, logisk grund, nytta och antaganden}

Syftet med den nordiska bedömningen av biologisk mångfald och ekosystemtjänster baserade på IPBES metoder och riktlinjer bör vara att stärka kopplingen mellan vetenskap och politik för biologisk mångfald och ekosystemtjänster, för bevarande och hållbart nyttjande av den biologiska mångfalden, långsiktig mänskligt välbefinnande och hållbar utveckling på nordisk nivå, samt att föda in resultaten till IPBES bedömning av Europa och Centralasien (ECA).

Omfattningen av den nordiska studien bör vara att bedöma frågor av betydelse i ett nordiskt sammanhang, såsom naturresursanvändning, exempelvis marina områden, bergsområden, jordbruk och markanvändning 
som påverkar arters livsmiljöer över nationsgränser, eller ekosystemtjänster; vanliga påverkansfaktorer i de nordiska länderna - såsom ändrad markanvändning - som skulle kunna inverka på livsmiljöer, biologisk mångfald och ekosystem i hela regionen; liknande kulturella och beteendemässiga aspekter såsom friluftsliv; likheter i förvaltning och styre, till exempel vad gäller skattesystemen; och ömsesidig påverkan mellan länderna, till exempel hur ett lands styre skulle kunna påverka hela regionen, eller hur nordisk förvaltning av gemensamma resurser bättre kan kopplas ihop.

Norden omfattar Danmark, Finland, Island, Norge, Sverige, Färöarna, Grönland och Åland. Det är viktigt att komma ihåg att trots att det finns många likheter mellan de nordiska länderna, är skillnaden i användningen av naturresurser stor. Detta kan illustreras genom ett antal exempel. Danmark är präglat av jordbruk, med över $65 \%$ av landytan använd till jordbruk, medan bara $1 \%$ av landytan i Island är brukad mark. I Finland och Sverige tar skog upp respektive $57 \%$ och $54 \%$ av landytan, jämfört med Danmark som bara har 9 \% skogstäcke (Kettunen, 2012). Finland och Sverige står tillsammans för 12,8\% av världsproduktionen av pappersmassa, vilket är en viktig exportprodukt för dessa två länder (Nordiska ministerrådet, 2014). I Island, Färöarna och Grönland är fiske den dominerande industrin, både vad gäller produktion och export - på Färöarna kommer nästan $89 \%$ av totala exportvärdet från fiskeindustrin, och på Grönland 63 \%. På Island är siffran nära 39 \%, jämfört med Danmark och Norge med cirka 3-4 \%, respektive 6-7 \% (Nordiska ministerrådet, 2014).

Den nordiska bedömningen bör i möjligaste mån använda IPBES konceptuella ramverk, IPBES riktlinjer och metoder, och grundtankarna för IPBES regionala och underregionala bedömningar. Bedömningen bör ta hänsyn till olika skalor såsom lokal, nationell och nordisk, liksom kopplingen till större internationell skala. Studien bör också samverka med andra initiativ inom området, såsom EUs MAES (Mapping and Assessment of Ecosystems and their Services) och ESMERALDA (Enhancing ecoSysteM sERvices mApping for poLicy and Decision mAking).

\section{Kunskapsbas}

Den nordiska bedömningen bör använda befintlig kunskap och data som innehas av globala, regionala, nordiska och nationella institutioner, såsom vetenskaplig litteratur och annan information inklusive medborgarvetenskap (citizen science) och lokal och traditionell kunskap. I enlighet med 
IPBES riktlinjer bör information hämtas från publicerad litteratur - inklusive så kallad grå litteratur - och från till exempel nationella vetenskapsakademier, nationella forskningsinstitut, statliga miljöorgan och statistikbyråer. Hänsyn till specifik nordisk kunskap och metadata bör diskuteras tidigt i projektet. Det kommer att vara av betydelse att bedöma mervärdet av detta, för att undvika onödigt dubbelarbete.

Den föreslagna kapiteldispositionen följer IPBES regionala och underregionala struktur, bestående av:

- Bakgrund.

- Ekosystemtjänster och mänskligt välbefinnande.

- Status, trender och framtida dynamik för biodiversitet och ekosystem.

- Direkta och indirekta påverkansfaktorer.

- Analys av samspelet mellan naturen och det mänskliga samhället.

- Alternativ för förvaltning och beslutsfattande över skalor och sektorer.

\section{Arbetsorganisation, tidplan och budget}

Ett sekretariat med deltidsanställd personal (medel för detta har sökts från Nordiska ministerrådet) på Naturvårdsverket i Sverige kunde underlätta att organisera arbetet, med början av 2016. Om ekonomin tillåter skulle en heltidstjänst vara att föredra. Projektet bör övervakas av en styrgrupp som kunde bestå av representanter från nationella myndigheter eller departement, och vars uppgift skulle vara att besluta om frågor av strategisk natur som uppstår under projektets gång. En expertgrupp av forskare och andra kunskapsbärare behöver också bildas, där medlemmarna efter nominering ska godkännas av styrgruppen. Nominering av författare bör följa IPBES arbetsordning. Den nordiska bedömningen skulle kunna organiseras i flera underbedömningar motsvarande de angivna fokusfrågorna, och med ledande institutioner/nav i de nordiska länderna för att stödja de utvalda författarna. Ett förslag till arbetsorganisering är beskrivet i detalj i avsnitt II av den här rapporten. Arbetet planeras att äga rum mellan 2016 och 2018, med en minimibudget på 450000 DKK per år (ej inräknat bidrag från forskare och andra kunskapsbärare). 


\section{Slutsats av förstudien, och vägen framåt}

Den här inledande studien har visat en möjlig väg för att etablera en nordisk bedömning av biologisk mångfald och ekosystemtjänster baserad på IPBES metoder och riktlinjer, genom att anta ett pragmatiskt förhållningssätt och ta hänsyn till strukturen för beslutsfattande i ett nordiskt sammanhang, samt de finansiella begränsningarna.

Tre viktiga frågor återstår att besvara:

- Förstudien har inte angett fokus för det fortsatta arbetet. Valet står mellan en övergripande och allmän bedömning i linje med de allmänna förstudierna för IPBES regionala och underregionala bedömningar av biologisk mångfald och ekosystemtjänster; eller att fokusera på ett ämne såsom sambandet mellan biologisk mångfald, ekosystem och de ekosystemtjänster de tillhandahåller, samt värdering av ekosystemtjänster för integrering och hållbart nyttjande; eller på en viss typ av ekosystem såsom hav, kust- och våtmarkssystem, eller skog. Fokus kommer att behöva beslutas $i$ början av själva studien.

- Processen för att besluta om fokus och omfattning måste definieras. Ett pragmatiskt sätt skulle kunna vara att skapa en styrelse som representerar de nordiska myndigheterna, och att undersöka möjligheten för ett uppstartsmöte inom ramen för Nordiska ministerrådet.

- Att hitta finansiering för ett brett deltagande i det arbete som utförs inom den nordiska bedömningen är en utmaning.

Dessutom beror projektets genomförbarhet på acceptans och engagemang från de nordiska ländernas regeringar, både vad gäller finansiering och hur bedömningen kommer att användas.

Flera utmaningar återstår att lösa innan en nordisk bedömning av biologisk mångfald och ekosystemtjänster baserad på IPBES metoder och riktlinjer kan etableras, men om man lyckas skulle en sådan studie kunna bidra till att möta det akuta behovet att stoppa förlusten av biologisk mångfald, och att öka förståelsen för biologisk mångfald, ekosystem och kopplingen till människors välbefinnande. 



\title{
Annex 1. Indigenous and Local Knowledge
}

\author{
Summary of report from Assignment to NAPTEK on \\ Indigenous and Local Knowledge in a Nordic \\ Assessment
}

Within the Nordic Scoping Study a separate, but interacting, study was performed regarding how best to include indigenous and local knowledge (ILK) in a future Nordic assessment, in line with the IPBES commitment to "Recognise and respect the contribution of indigenous and local knowledge to the conservation and sustainable use of biodiversity and ecosystems". ${ }^{43}$ This commitment has led IPBES to form a specific Task Force for Indigenous and Local Knowledge, and to develop procedures and approaches for ILK in IPBES. The aim of the Nordic scoping study on ILK was to develop a Nordic methodology to be applied in a full Nordic IPBES assessment of biodiversity and ecosystem services. At the same time, it is hoped that it will contribute to the IPBES experiences globally on how to connect between indigenous, local and scientific and other knowledge systems. This methodology should fulfil the requirements of legitimacy, credibility and usefulness for all involved, and full and active participation, reciprocity and free, prior informed consent (FPIC), ${ }^{44}$ as outlined in a Multiple Evidence Base approach.45

The ILK study within the scoping study of a Nordic assessment was financed by the Swedish Environmental Protection Agency and assigned to the Swedish Biodiversity Centre and the section known as NAPTEK (Swedish National Programme on Local and Traditional Knowledge related to Conservation and Sustainable Use of Biodiversity). NAPTEK was initiated in 2005 by the Swedish Government in order to contribute to a

\footnotetext{
43 UNEP/IPBES.MI2/9 Appendix 1, para 2d.

${ }^{44}$ For a definition of free, prior and informed consent, see Guidelines for Considering Traditional Knowledges in Climate Change Initiatives Version 1.0 - September 2014, https://climatetkw.wordpress.com/guidelines/

45 A Multiple Evidence Base approach emphasises the complementarity of knowledge systems, without assigning any one knowledge system as the dominant one. See Tengö et al. 2014, Ambio 43, 579-591, http://link.springer.com/article/10.1007\%2Fs13280-014-0501-3
} 
Swedish implementation of Article 8(j) of the UN Convention on Biological Diversity (CBD). Since then, NAPTEK has been acting in the space between holders of ILK, practitioners, academia, and governmental agencies and has developed different networks. This interface has created a credible base for this assignment. The assignment was dealt with as four connected activities, in order to fully consider the perspectives of the ILK actors and the particular context of the IPBES in a Nordic setting:

1. A Nordic dialogue workshop for ILK actors.

2. An ILK questionnaire focusing on how to achieve full and effective ILK participation in practice.

3. A project piloting local ILK workshops implemented by Snowchange Cooperative (an ILK NGO) in Finland.

4. An interview and literature study about citizen science in the Nordic countries and its potential contribution to a Full Nordic IPBES Assessment.

Limitations of the ILK study within the Scoping Study: The project was done over a relatively short time and during the summer season, which limited the opportunities for ILK representatives, who practise their knowledge in their day-to-day management of biodiversity and ecosystems, to fully and effectively take part. Despite these constraints, the ILK workshop, as well as the questionnaire, gathered input from a diverse group of highly qualified holders of indigenous and local knowledge from all the Nordic countries including the autonomous areas Kalaallit Nunaat (Greenland), Føroyar (Faroe Islands) and Åland.

\section{Results from the ILK study}

The different parts of the ILK study gave a fairly uniform picture of how full and effective participation of ILK in a future Nordic Assessment ought to be achieved. The following reflections need to be addressed or reflected upon:

The indigenous (Sami and Inuit) and local knowledge holders from all Nordic countries have much in common regarding knowledge and values in relation to their respective landscapes and biodiversity. They also share similar challenges related to recognition of their knowledge and rights. 
The classical definition of traditional ecological knowledge by Fikret Berkes $^{46}$ is also a workable definition of ILK also in a Nordic context:

- A cumulative body of knowledge, practice and beliefs, evolving by adaptive processes and handed down through generations by cultural transmission, about the relationship of living beings (including humans) with one another and with their environment.

Based on experiences from the various activities performed, and data collected within the Nordic ILK Scoping project, it is obvious that there is extensive cultural and biocultural diversity in the Nordic countries that could contribute to a Nordic assessment. In addition to representatives of indigenous peoples in the area, the Sami and the Inuits, there are many groups with local and traditional knowledge directly linked to customary use of local biological resources. Local communities with a continuity of observations regarding the state of the environment and its biodiversity could contribute substantially to community-based monitoring initiatives, and above all represent a tradition of long-term sustainable use of biological resources, thus contributing to local governance of biodiversity and landscapes, and potential long-term food security for the whole of society. Groups that were identified as relevant for possessing ILK of value for a Nordic assessment, in addition to indigenous peoples includedhunters; small-scale fishermen; small-scale farmers (e.g. summer pastoralists, archipelago farmers); allotment growers; associations for local breeds or local varieties; local history societies; associations with interests in cultural landscapes; the Transition movement; and people involved in traditional agricultural techniques, like hay-cutting, grazing, and pollarding for conservation biology. Museums, outdoors museums and especially museum farms are also important actors, and play an important role in public awareness and in linking present-day traditional knowledge to the historic past. From a citizen science point of view, groups such as bird watchers, amateur botanists and entomologists, environmental NGOs and similar groups are highly relevant. Finally, there are particular individuals that, based on their own capacity, could make major contributions.

${ }^{46}$ Berkes, F. (1993). Traditional ecological knowledge in perspective. In Traditional Ecological Knowledge: Concepts and Cases, J. T. Inglis (ed.). Ottawa: International Program on Traditional Ecological Knowledge and International Development Research Centre. Pp 1-9. 
In the dialogue workshop, some of the basic qualities raised were:

This knowledge is found "among the local people, who are living on the land and using the biodiversity" and "based on direct observations and experiences". It is "knowledge learnt from parents and grandparents, not taught in schools, and you always have it with you... It is practical knowledge that you in turn hand on to the next generation." and it is "knowledge of the heart, hand and mind". It is often "silent" knowledge based on shared experiences.

Both IPBES and a Nordic assessment of biodiversity and ecosystem services are difficult to grasp for people outside the "IPBES circles". The language and context presented about IPBES and a future Nordic assessment were viewed as very academic, convoluted and exceedingly complex. The context, objectives and expected results have to be made clear and understandable. It is critical also to explain clearly the possible long-term outcome of IPBES - including in what way it might support holders of ILK, as well as society at large, but also to ensure that the dialogues positively influence the present situation for the participating ILK holders.

It is important to understand the local use of biological resources as an ecological factor and the importance of a continuation of customary sustainable use, both for biodiversity and for local communities, as well as for society at large.

Contributions can be made from Nordic Community-Based Monitoring initiatives and citizen science initiatives and the databases that are created through such initiatives in all the Nordic countries.

The local context is important, both for the biodiversity and the validity of the indigenous and local knowledge. Consequently, there is a need to put local consultations on the agenda early, and adapt the timing to the appropriate season for the particular community.

Full and effective participation needs to be on equal terms. Most officials from agencies or academia participate in their professional capacity, while ILK representatives typically need reimbursement for travel costs, for their own time and, in many cases, for costs of hiring staff to look after livestock and maintaining necessary farm or other activities in their absence.

During the project, many holders of indigenous and local knowledge in the Nordic countries have confirmed their interest in sharing and exchanging their knowledge with others. In doing so, it is, however, important for them to gain a good understanding of what IPBES is, and what outcomes to expect. It is important that the organisation of the assessment work is entirely based on equity, legitimacy and reciprocity, and that it aims for credibility, and usefulness for all involved. 


\section{Proposals for a Nordic assessment that includes ILK}

- Ensure that the full diversity of indigenous (Sami and Inuit) and local knowledge in the Nordic countries is welcomed to contribute to a Nordic assessment, based on equity and reciprocity across knowledge systems. Self-identification among those who want to contribute, whether indigenous or local holders of knowledge, would be the most workable approach.

- A number of thematic and regional dialogue workshops with ILK experts should be held in the different Nordic countries in the language of the knowledge holders. The aim of the workshops would be to obtain ILK inputs into the full process of the Nordic assessment of biodiversity and ecosystem services, including in the planning phase, and in the documentation and analysis of knowledge in the assessment. There is a need for local dialogue workshops at the beginning of the assessment work in order to obtain "unpublished" input to the assessment as well as workshops in the later stages to validate the written conclusions from an ILK perspective.

- There is a need for ILK knowledge holders to have equal opportunities, compared with researchers, to prepare for and to participate in a future Nordic assessment.

- The role of ILK in the Nordic assessments needs to be clearly stated, as well as the expected outcome of the participatory processes. It is important to ensure that holders of knowledge are obtaining meaningful outcomes from the process, in relation to their livelihood realities.

- Participation needs to be based on Free Prior Informed Consent, and proper risk assessment for sharing knowledge should be done on a case-by-case basis when working with ILK holders. Demands for legitimacy, credibility, transparency, trust and equity need to be met. Available ethical codes of conduct should be used.

- The process of inclusion of ILK should start with invitations through nominations with open criteria, ensuring that organisations as well as individuals can nominate themselves. It is necessary to strive towards open criteria for indigenous, geographical, cultural and gender balance. Conditions for participation should be explained beforehand, such as provision of compensation for loss of income and for extra costs incurred. Expected beneficial outcomes of the process, such as benefits from exchange and learning with other holders of knowledge, should also be clear. 
- A broad roster of ILK experts, representing a variety of different customary uses of different ecosystems, should be compiled. This could be used for specific issues or themes in the Nordic assessment process. This roster could be used for other kinds of exchange, based on free, prior and informed consent.

- The Nordic assessment should include exchange across knowledge systems by using non-conventional methods, e.g. by inviting to walking workshops in habitats of interest, for ILK experts, other experts and policy makers. A common meeting ground in the field would create inter-cultural spaces for learning and stimulate implementation of findings.

- The ILK process in a Nordic assessment should actively contribute to protection and promotion of the indigenous and knowledge, including its implementation and transmission to new generations.

- The process needs to include an emphasis on how to make different values visible and weighted in policy decision-making processes that build on IPBES outcomes.

- Within the Nordic countries, there are several databases created from citizens' observations, that could: 1) contribute data on biodiversity and ecosystem services of high relevance for a Nordic assessment; and 2) contribute a space for engaging with a group in society with expertise in and commitment to biodiversity and ecosystem services, for its outreach activities. A Nordic assessment should take advantage of these, both for its data gathering, and for capacity building and communication and outreach activities.

- Community Based Monitoring has high potential to contribute not only data, but also analysis and conclusions, based on its monitoring. Ongoing initiatives in the Nordic countries should been taking care of, and actively be invited to engage in a Nordic assessment. 


\section{Annex 2.}

Examples of processes, literature and data sources (more information available in Excel files, available upon request from SEPA) 
Table 1: Nordic - Examples of relevant processes, literature and data sources

\begin{tabular}{|c|c|c|c|c|c|c|}
\hline Area & Name & Authors & Affiliation & Year & Address/Link & Comment \\
\hline \multicolumn{7}{|c|}{ Nordic } \\
\hline & TEEB Nordic & & TEEB & & $\begin{array}{l}\text { http://www.teebweb.org/countryprofile/ } \\
\text { nordic-countries/ }\end{array}$ & \\
\hline & TEEB Arctic & & TEEB & & http://arcticteeb.net/ & \\
\hline & & & Nordregio & & http://www.nordregio.se/ & $\begin{array}{l}\text { Interesting information about the } \\
\text { region and also maps }\end{array}$ \\
\hline & NordMap & & Nordregio & & $\begin{array}{l}\text { http://www.nordregio.se/System/News/ } \\
\text { New-NORDMAP-web-mapping-tool-Create- } \\
\text { share-and-print-maps/ }\end{array}$ & $\begin{array}{l}\text { NordMap is the name of a new Nordic } \\
\text { web-mapping tool for demography, la- } \\
\text { bour market and accessibility in the } \\
\text { Nordic countries. With NordMap you } \\
\text { can analyse local and regional develop- } \\
\text { ment trends and create, share and } \\
\text { print customised maps without any } \\
\text { previous mapping or GIS experience }\end{array}$ \\
\hline & & & Norden & & http://www.norden.org/en & $\begin{array}{l}\text { Interesting information about the } \\
\text { region and also maps }\end{array}$ \\
\hline & Nordic Nature - trends towards 2010 & & & & $\begin{array}{l}\text { http://www.syke.fi/en-us/ } \\
\text { Research_Development/ } \\
\text { Research_and_development_projects/ } \\
\text { Projects/Nordic_nature_trends_towards_2010 }\end{array}$ & $\begin{array}{l}\text { A Nordic communication project on } \\
\text { biological diversity financed by the } \\
\text { Nordic Council of Ministers }\end{array}$ \\
\hline & Arctic Portal & & & & http://www.arcticportal.org/ & $\begin{array}{l}\text { Interesting information about the } \\
\text { region and also maps }\end{array}$ \\
\hline & $\begin{array}{l}\text { The Nordic Aichi restoration project : How can } \\
\text { the Nordic countries implement the CBD tar- } \\
\text { get of restoration of } 15 \% \text { of degraded ecosys- } \\
\text { tems by } 2020 \text { ? }\end{array}$ & $\begin{array}{l}\text { Hagen, Dagmar; Lindhagen, } \\
\text { Anna; Päivinen, Jussi; } \\
\text { Svavarsdóttir, Kristin }\end{array}$ & $\begin{array}{l}\text { Nordic Council of Ministers, } \\
\text { Secretariat of Nordic Council of } \\
\text { Ministers }\end{array}$ & 2015 & $\begin{array}{l}\text { http://norden.diva-portal.org/smash/ } \\
\text { record.jsf?pid=diva2\%3A806026\&dswid=9439 }\end{array}$ & \\
\hline & $\begin{array}{l}\text { Local knowledge and resource management: } \\
\text { On the use of indigenous and local knowledge } \\
\text { to document and manage natural resources in } \\
\text { the Arctic }\end{array}$ & & $\begin{array}{l}\text { Nordic Council of Ministers, } \\
\text { Secretariat of Nordic Council of } \\
\text { Ministers }\end{array}$ & 2015 & $\begin{array}{l}\text { http://norden.diva-portal.org/smash/ } \\
\text { record.jsf?pid=diva2\%3A791816\&dswid=-3879 }\end{array}$ & \\
\hline & $\begin{array}{l}\text { The Nordic Region leading in green growth: } \\
\text { Status report for the Nordic Prime Ministers } \\
\text { Summer Meeting, } 27 \text { May } 2014\end{array}$ & & $\begin{array}{l}\text { Nordic Council of Ministers, } \\
\text { Secretariat of Nordic Council of } \\
\text { Ministers }\end{array}$ & 2014 & $\begin{array}{l}\text { http://norden.diva-portal.org/smash/ } \\
\text { record.jsf?pid=diva2\%3A732564\&dswid=-8007 }\end{array}$ & \\
\hline
\end{tabular}


Fisheries Management and Global Warming Effects of climate change on fisheries in the

Nordic Council of Ministers, Arctic region of the Nordic countries

Nordic Environmental Action Plan 2013-2018

Nordic Sustainable Development Indicators 2013

The Arctic Biodiversity Assessment

Protection of the Arctic Marine Environment (PAME) report on Identification of Arctic marine areas of heightened ecological and cultural significance: Arctic Marine Shipping Assessment (AMSA) Ilc

Conservation of Arctic Flora and Fauna (CAFF)

Nordic Council of Ministers, Ministers

Nordic Council of Ministers, Ministers

CAFF, Arctic Counci
Secretariat of Nordic Council of Secretariat of Nordic Council of Secretariat of Nordic Council of

http://www.amap.no/documents/doc/ identification-of-arctic-marine-areas-o heightened-ecological-and-culturalsignificance-arctic-marine-shippingassessment-amsa-iic/869
(English) Book (Other scientific)

(English) Other (Other (popular sci-

ence, debate, etc.))

(English) Book (Other scientific)

The purpose of the Arctic Biodiversity Assessment (ABA) is to synthesise and assess the status and trends of biological diversity in the Arctic. It identifies the current status of and historical trends in population size and distribution of Arctic species and, where available, presents projections of future change. As data on this scale are only available for a few well-known species and ecosystems, it is not possible to provide a comprehensive acsible to provide a comprehensive acArctic biodiversity

CAFF is governed by a Chair and Management Board that consists of $\mathrm{Na}$ tional Representatives assigned by each of the eight Arctic Council Member States and Permanent Participants representing the six Indigenous Peoples' organisations of the circumpolar north

Arctic 
https://www.cbd.int/doc/world/dk/

on Biological Diversity

Miljørapport 2015 (Environmental Report

2015)

Biodiversitetskort For Danmark (Biodiversity Map For Denmark)
The Danish Ministry of Environment and Food

Centre for Macroecology, Evoluation and Climate at Copenhagen University and Institute of Bioscence at Aarhus University
Comment

Arctic

ELOKA facilitates the collection, preservation, exchange and use of localobservations and knowledge of the Arctic. ELOKA provides data manement and user support, and fosters col ricts

Huge network of networks including scientists and other experts in ecosystem and biodiversity monitoring in the Arctic. Chaired by US and Greenland/ Denmark. Organised through four Steering groups for Marine, Terrestrial, coastal and freshwater ecosystems. Will present assessments in coming years - first one will be Marine in 2017

Economy and Environment 2012 contains three chapters, which are: Chapter I: Danish environmental policy 2000-2010Chapter II: Biodiversit/ Chapter III: Genuine saving In addition, the report contains a Danish summary, an English summary and the written comments of the Council members

Download the report by clicking in the menu on the right

Danish submission to the CBD notification (2013-050) on information for the review of Implementation of the Strategy for Resource Mobilisation

Developed in cooperation between Centre for Macroecology, Evoluation and Climate at Copenhagen University and Institute of Bioscence at Aarhus University 
Area Name

Authors

Affiliation

Ministry of the Environment

Digitale Naturkort - til Et grønt Danmarkskort

(Digital Nature Maps - for a green map of Den-

Faroe islands

(FO)

TBD

reenland

(GL)
The Nuuk Basic and Zackenber Basic secretariats

$$
\text { Aarhus University }
$$

Aarhus University

Christensen, Aastrup, Boye,

Boertmann, Hedeholm, Jo-

hansen, Merkel, Rosing Asvid,

Bay, Blicher, Clausen, Ugarte,

Arendt, Burmeister, Topp-

Jørgensen, Retzel,

Hammeken, Falk, Frederiksen,

Bjerrum, Mosbech

Five different Strategic Environmental Impact Assessments for Greenland:

Eastern Baffin Bay

Disko West

Western Greenland Sea

South Greenland

The Davis Strait

2) Boertmann $D$, Mosbech

Identifi kation af sårbare marine områder i den Christensen, Falk, Boye,

grønlandske/danske del af Arktis (Identifica- Ugarte, Boertmann, Mos-

tion of vulnerable marine areas in the Green- bech, $A$.

landic/Danish part of the Arctic)

Biologiske beskyttelsesområder I National-

parken I Nord- og Østgrønland (Biological pro-

tection zones in the National Park in North and

East Greenland
1) Boertmann, Mosbech

(eds.)

A. Schiedek, D. \& Dünweber,

M. (Eds.)

3) Boertmann, D. \&

Mosbech, A. (eds.)

4) Frederiksen, M., Boert-

, F. Mos-

bech, A. (eds)

(a)

Mosbech, A. \& Ugarte, $F$ (eds)

Aastrup, Boertmann

Aarhus University

Aarhus University, Greenland In-

stitute of Natural

http://www2.dmu.dk/Pub/SR9.pdf

http://dce2.au.dk/pub/SR71.pdf

http://www2.dmu.dk/Pub/SR22.pdf

http://www.dmu.dk/Pub/SR23.pdf

http://www.dmu.dk/Pub/SR15.pdf

http://www2.dmu.dk/pub/sr43.pd

2009

http://dce.au.dk/udgivelser/

udgivelser-fra-dmu/faglige_rapporter/

700-749/abstracts/fr_ 729_dk/
Greenland Ecosystem Monitoring (GEM) is a leading integrated monitoring and long-term research programm on ecosystems and climate change 


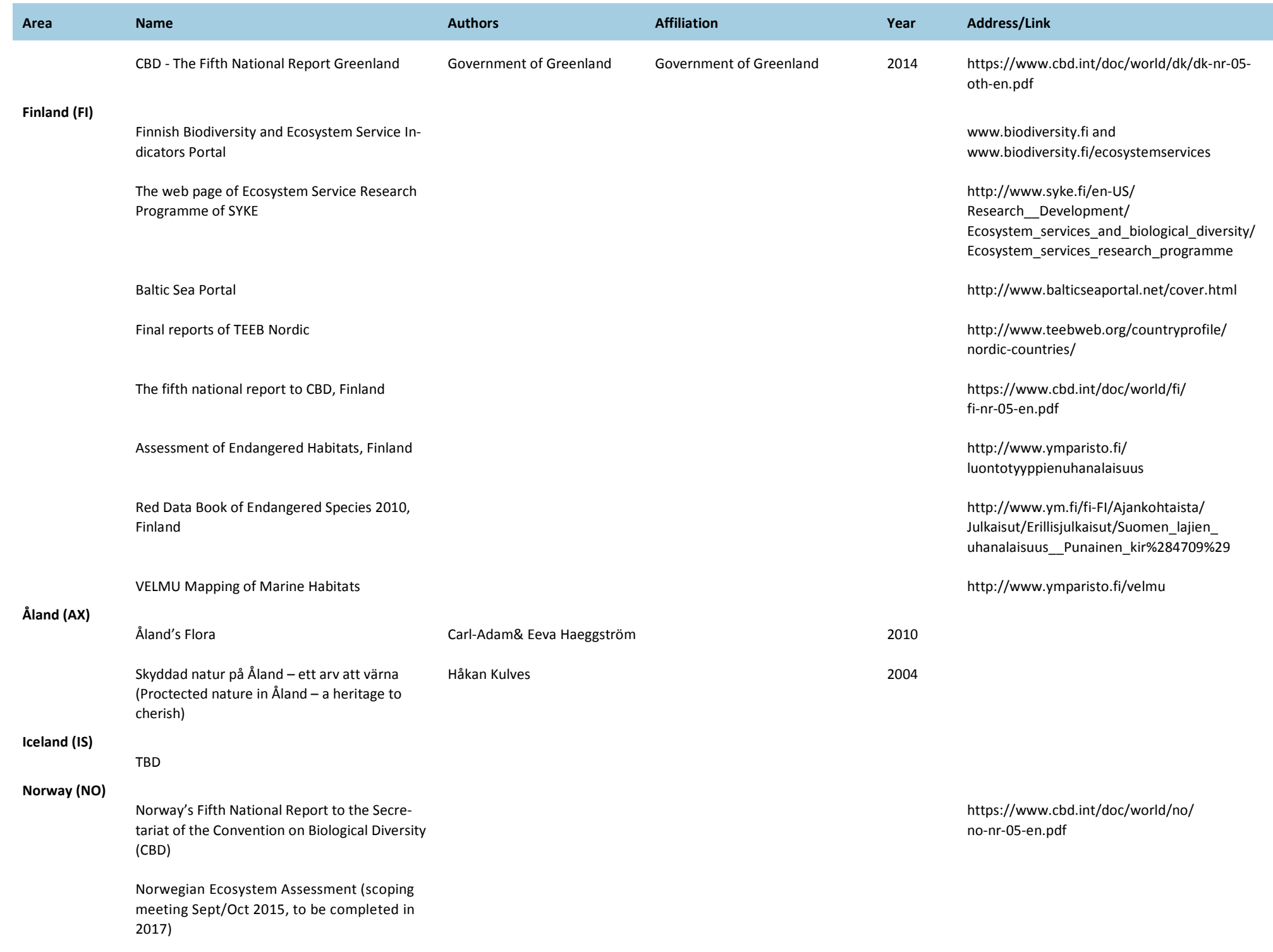
eeting Sept/Oct 2015, to be completed in 
Norges offentlige utredninger 2013:10, “Na-

turens goder - om verdier av økosys-

temtjenester" (Official Norwegian Report

"Natural benefits - on the values of ecosystem services"). Full report (in Norwegian)

Naturindeks for Norge 2010/The Norwegian Ecosystem Index 2010. Full report

(in Norwegian)

Norsk Rødliste for Arter 2010/The 2010 Norwegian Red List for Species

Norsk rødliste for naturtyper/Norwegian Red List for Ecosystems and Habitat Types (2011)

Fremmede arter i Norge - med norsk svarteiste 2012/Alien species in Norway - with the Norwe

Mennesket og naturarven (Humankind and the natural heritage) (MONA)

Sweden (SE)

FOMA - fortlöpande miljöanalys (FOMA - continuous environmental analysis)

Land accounts for biodiversity - a methodological study https://www.regjeringen.no/nb/

dokumenter/nou-2013-10/id734440/.

http://www.miljodirektoratet.no/old/ dirnat/attachment/1622/DN-utredning-32010_nett_ny.pd

English summary:

irektoratet.no/old/

Tent/2246/DN-Report-1

2011.pdf

http://www.artsdatabanken.no/article/ article/133430).

http://www.artsportalen.artsdatabanken.no/ \#/RodlisteNaturtyper/Vurderinger/.

The report in English:

http://www.artsdatabanken.no/File/688/

Rødliste\%20for\%20naturtyper\%20engelskk

http://www.artsdatabanken.no/File/

687/Fremmedearter2012) and

English:http://www.artsdatabanken.no/File/

689/Alien\%20species

http://www.miljodirektoratet.no/no/Tema/ Kulturlandsap/Mennesket-og-naturarven/

http://www.slu.se/sv/miljoanalys/

om-fortlopande-miljoanalys/

Statistics Sweden 2015

[t//www.scb.se/Statistik/Publikationer/ MI1301_2014A01_BR_MI71BR1503.pdf
A revised version is expected in 2015

revised version is expected in 2015 ook at who owns the land as part of the assessment. That way it is east of link the biodiversity data to other to cion ciassme This type of work could be esments. This type of work could be done in the orher Nordic countries as down in scale to smaller regions 
Inventory of data sources for quantification of ecosystem services

Traditional ecological knowledge among reinInga, B deer herders in Northern Sweden

Swedish Government Inquiry 2013:68 - Synliggöra värdet av ekosystemtjänster. -

Atgärder för välfärd genom biologisk mångfald och ekosystemtjänster (2013) Making the value of ecosystem services visible, Summary of SOU 2013:68, Stockholm 2013

A Swedish strategy for biodiversity and ecosystem services

Inventory of data sources for quantification of ecosystem services

Mapping and assessment of ecosystems and their services: The Swedish Forest Pilot

Sverige och konventionen om biologisk mångfald (Sweden and the Convention on Biologica Diversity)

Bevarande av biologisk mångfald - instrumen och omfattning (Conservation of biological diversity - instruments and scope)

Sweden's Fifth National Report to the Secretariat for the Convention on Biological Diversity

Environmental Quality Objectives

Svenska miljöövervakningsprogrammet (Swedish environmental monitoring programme)

Swedish University of Agricultural $\quad 2008$ Studies, Umeå

http://pub.epsilon.slu.se/1947/1/

inga_b_lic_2008_20090303.pdf

2013 www.regeringen.se/content/1/c6/22/

61/92/97321dd6.pdf

summary in English

http://www.teebweb.org/wp-content/

ecosystem-services-visible_Sweden_2013.pd

http://www.government.se/sb/d/

3879/a/236303

SCB (Statistics Sweden)

swedish Nature Protection http://www.scb.se/statistik/_publikationer/

MI1301_2013102_BR_MI71BR1302.pdf

http://www.naturvardsverket.se/

Om-Naturvardsverket/Publikationer/

ISBN/6600/978-91-620-6626-0/

http://www.naturvardsverket.se/Miljoarbete-

-samhallet/EU-och-internationellt/

Internationellt-miljoarbete/miljokonentioner/

Konventionen-om-mangfald/Sveriges-arbete/

http://www.naturvardsverket.se/

Nerladdningssida//fileType=pdf\&downloadUrl=/ upload/miljoarbete-i-samhallet/internationelltmiljoarbete/milok

https://www.cbd.int/doc/world/se/ se-nr-05-en.pdf

http://miljomal.se/Environmental-ObjectivesPortal/Undre-meny/About-the-EnvironmentalObjectives/Achieved/

http://www.naturvardsverket.se/Miljoarbete-samhallet/Miljoarbete-i-Sverige/

Miljoovervakning/ 
Svenska nationella miljöindikatorer

(Swedish national environmental indicators)

The Swedish Species Information Centre/

Artdatabanken

Marine ecosystem services - Marecos. Marine Hasler, B. et al. ecosystem services in Nordic marine waters and the Baltic Sea - possibilities for valuation

Methods for valuing ecosystem services, Subreport in the project "Mapping of ecosystem services"

An ecosystem service approach for analysing marine human activities in Sweden (report 2012:8)

The research initiative Value of Ecosystem Services

The NILS ESS project collates and analyses information from NIIS

Value of Underwater Habitats' Ecosystem Services

Integrera ekosystemtjänster i kommunal planering genom strategisk miljöbedömning Ikvartärgeologi (Integrating ecosystem services in municipal planning through strategic environmental assessment in quaternary geology), Stockholm University

SGU report 2014:40, "Grundvattnets ekosystemtjänster och deras ekonomiska värden en inledande kartläggning" (Ecosystem services of gorundwater and their economic values - an introductory analysis)
http://www.miljomal.se/Miljomalen/

Alla-indikatorer/

http://www.artdatabanken.se/en/

The Swedish Species Information Centre works on biodiversity, serving as the focal point for information on

threatened species and biodiversity in sweden.
City of Malmö

Swedish Agency for Marine and Water Management

Nationell inventering av landskapet i Sverige, NILS ESS

Sanna Almheden

Case study from the Municipality of Järfälla. Department of Natural Geography and Quaternary Geology, Stockholm University kartlaggning/ 


\begin{tabular}{|c|c|c|c|c|c|c|}
\hline Area & Name & Authors & Affiliation & Year & Address/Link & Comment \\
\hline & $\begin{array}{l}\text { Metria maps ecosystem services - different } \\
\text { mapping methods }\end{array}$ & & & & $\begin{array}{l}\text { http://metria.se/Om-Metria/Nyheter/ } \\
\text { Kampanj-Nyheter/Ekosystemtjanster/ }\end{array}$ & \\
\hline & & & SOM-Institutet & & http://som.gu.se/undersokningar & \\
\hline & $\begin{array}{l}\text { Utredning av status och trender rörande lokal } \\
\text { och traditionell kunskap i Sverige (Investigat- } \\
\text { ion of status of and trends in local and tradit- } \\
\text { ional knowledge in Sweden) }\end{array}$ & Tunón, H. et al. & Swedish Biodiversity Centre & 2010 & $\begin{array}{l}\text { http://www.slu.se/Global/externwebben/ } \\
\text { centrumbildningar-projekt/centrum-for- } \\
\text { biologisk-mangfald/Dokument/ } \\
\text { publikationer-cbm/cbm-skriftserie/skrift39.pdf }\end{array}$ & \\
\hline & $\begin{array}{l}\text { Webbaserad kunskapsportal för traditionell } \\
\text { kunskap relaterad till biologisk mångfald - en } \\
\text { förstudie (Online knowledge portal for tradi- } \\
\text { tional knowledge related to biodiversity - a } \\
\text { preliminary study) }\end{array}$ & Dahlström, A. \& Tunón, H. & Swedish Biodiversity Centre & 2011 & $\begin{array}{l}\text { http://www.slu.se/Global/externwebben/ } \\
\text { centrumbildningar-projekt/centrum-for- } \\
\text { biologisk-mangfald/Dokument/publikationer- } \\
\text { cbm/cbm-skriftserie/ } \\
\text { CBMskrift72WebbaseradKunskapsportal.pdf }\end{array}$ & \\
\hline & $\begin{array}{l}\text { Nybyggarliv i Vilhelmina I-V (Life of new set- } \\
\text { tlers in Vilhelmina I-V) }\end{array}$ & Kjellström, R & $\begin{array}{l}\text { Kungl. Gustav Adolfsakademien \& } \\
\text { Swedish Biodiversity Centre }\end{array}$ & $\begin{array}{l}2012- \\
2015\end{array}$ & & \\
\hline & $\begin{array}{l}\text { Fäbodskogen som biologiskt kulturarv (Summer } \\
\text { pasture forest as biological cultural heritage) }\end{array}$ & Ljung, $T$ & Swedish Biodiversity Centre & 2011 & $\begin{array}{l}\text { http://www.slu.se/Global/externwebben/ } \\
\text { centrumbildningar-projekt/centrum-for- } \\
\text { biologisk-mangfald/Dokument/publikationer- } \\
\text { cbm/cbm-skriftserie/skrift49.pdf }\end{array}$ & \\
\hline & $\begin{array}{l}\text { Ecomapping i Kustringen: Kunskap är makt - lo- } \\
\text { kal kunskap och lokalt inflytande (Ecomapping } \\
\text { in the Coastal Ring: Knowledge is power - local } \\
\text { knowledge and local influence) }\end{array}$ & Nilsson, P. \& Tivell, A. & Swedish Biodiversity Centre & 2011 & $\begin{array}{l}\text { http://www.slu.se/Global/externwebben/ } \\
\text { centrumbildningar-projekt/centrum-for- } \\
\text { biologisk-mangfald/Dokument/publikationer- } \\
\text { cbm/cbm-skriftserie/skrift56.pdf }\end{array}$ & \\
\hline & $\begin{array}{l}\text { Synen på ekosystemtjänster - begreppet och } \\
\text { värdering (Views of ecosystem services - the } \\
\text { concept and valuation) }\end{array}$ & & $\begin{array}{l}\text { naturvardsverket.se/ } \\
\text { ekosystemtjanster }\end{array}$ & 2014 & & $\begin{array}{l}\text { The Swedish Environmental Protection } \\
\text { Agency has been tasked with com- } \\
\text { municating the value of ecosystem ser- } \\
\text { vices over the period 2014-2017 }\end{array}$ \\
\hline & $\begin{array}{l}\text { Guide för värderingav ekosystemtjänster } \\
\text { (Guide to valuation of ecosystem services) }\end{array}$ & & $\begin{array}{l}\text { Swedish Environmental } \\
\text { Protection Agency }\end{array}$ & 2015 & Report 6690 & \\
\hline & $\begin{array}{l}\text { Ekosystemtjänster i svenska skogar } \\
\text { (Ecosystem services in Swedish forests) }\end{array}$ & Hansen , Mameaus, Lindblad & IVL & 2014 & Report B2190 & \\
\hline
\end{tabular}


Table 2: European - Examples of relevant processes, literature and data sources

Area $\quad$ Name

European

Ecosystem Services and Biodiversity

Biodiversity Information System for Europe (BISE)

ESMERALDA

Habitats Directive progress reporting

MAES

Operationalisation of Natural Capital and

Ecosystem Services, Openness

OPERAS

UK- NEA
Affiliation

Year

2015

Authors

http://biodiversity.

europa.eu/info

http://www.esmeralda-

project.eu/

2015

http://ec.europa.eu/

environment/

nature/knowledge/

rep_habitats/

http://biodiversity.

europa.eu/maes

http://www.openness-

project.eu/

http://www.operas-

project.eu/
Comment

Science for Environment Policy ISBN 978-92-79-45727-2

The Biodiversity Information System for Europe (BISE) is a single entry point for data and information on biodiversity supporting the implementation of the EU strategy and the Aichi targets in Europe

ESMERALDA aims to deliver a flexible methodology to provide the building blocks for pan-European and regional assessments

Article 17 of the Habitats Directive requires the Member States to report on the status of the implementation of the Directive every six years. The Commission then produces a synthesis report based on the national reports.

documents and literature in connection to MAES

OpenNESS aims to translate the concepts of Natural Capital (NC) and Ecosystem Services (ES) into operational frameworks that provide tested, practical and tailored solutions for integrating ES into land, water and urban management and decision-making. It examines how the concepts link to, and support, wider EU economic, social and environmental policy initiatives and scrutinises the potential and limitations of the concepts of ES and NC

OPERAs is a European research project which aims to bridge the gap between ecosystem science and practice. The project has 27 partners from academic institutions, consultancies and SMEs across Europe. The OPERAs team comprises scientists, research at constitutes good governance of ecosystems,

The UK National Ecosystem Assessment (UK NEA) was the first analysis of the UK's natural environment in terms of the benefits it provides to society and continuing economic prosperity. From short questionnaire: See for example the UKNEA follow-on WP 6 on shared values of ecosystem services (ES), focussing on cultural ES 
IPBES - Regional Assessment Europe and Central

$$
\text { Asia (ECA) }
$$

The Intergovernmental Platform for Biodiversity and Ecosystem Services (IPBES) is currently preparing the regional and subregional assessment of biodiversity and ecosystem services in Europe and Central Asia (ECA), with the target subregions Western Europe, Eastern Europe and Central Asia, including an analysis of the current status, trends, future forecasts, and expected impacts on human society (IPBES deliverab 2b). The Technical Support Unit for the Region Assessmety for Europe and Central Asia, hosted by the University of Bern, is managing the organisational and administrative activities of the Regional ECA Assessment

Linking Indigenous and Scientific Knowledge of Eira, I.M.G. et al. Climate Change

"Local Knowledge"

The Diversity of Sacred Lands in Europe
Petersen

Maynard, N.G. et IUCN al.
2013

2011
And other work by H.C. Petersen (1925-2015)

ILK Proceedings of the Third Workshop of the Delos Initiative Inari/Aanaar 2010

Table 3: International - Examples of relevant processes, literature and data sources

Issue Name process publications Authors

Affiliation

Year

\section{Address/Link}

Ecosystem

Assessments

CBD Country profiles

Intergovernmental Science-Policy Platform on Biodiversity and Ecosystem Services (IPBES)

The IPBES Conceptual Framework - connecting nature and Díaz, S. et al. people

The Millennium Ecosystem Assessment (MA) https://www.cbd.int/countries/default.shtml

http://ipbes.net/

2015 Current Opinion in Environmental Sustainability 14:1-16

http://www.maweb.org/documents/document.299.aspx.pdf

The Millennium Ecosystem Assessment was a report ordered by UN and involved more than 1,360 experts worldwide. Their findings provide a state-ofthe-art scientific appraisal of the condition and trends in the world's ecosystems and the services they provide and options for sustaining ecosystem 
Manual for Assessment Practitioners

Programme on Ecosystem Change and Society (PECS) and

\section{SAPECS (South African PECS)}

World Resources Institute, WRI, has developed tools for ecosystem services assessment, such as the ones described below

The Ecosystem Services Guide For Decision Makers

The Corporate Ecosystem Services Review (ESR) - Guidelines for Identifying Business Risks \& Opportunities Arising from Ecosystem Change

The Ecosystem Services Review for Impact Assessment (ESR for IA)

Common International Classification of Ecosystem Services (CICES)

Project for Ecosystem Services (ProEcoServ)

OECD DAC SEA and Ecosystem Services Advisory Not .ecosystemassessments.net/

The Sub-Global Assessment Network (SGAN) is a community of practice that connects and supports individuals and organisations involved in ecosystem assessments at regional, sub-regional, national and sub-national levels

htp://www unep-wcmc.org/medialibrary/ 2010/10/31/90af3045/

Ecosystems HumanWellbeing.pdf

http://www.stockholmresilience.org/21/ research/research-programmes/pecs.htm

http://www.sapecs.org/about/

http://www.wri.org/publication/

ecosystem-services

http://www.wri.org/publication/corporate-

ecosystem-services-review

http://www.wri.org/publication/weaving-ecosystem-services-into-impact-assessment

http://cices.eu/

http://www.proecoserv.org/

http://www.seataskteam.net/guidance php
The Common International Classification of Ecosystem Services (CICES) developed from the work on environmental accounting undertaken by the European Environment Agency (EEA). It supports their contribution to the revision of the System of Environmental-Economic Accounting (SEEA) which is currently being led by the United Nations Statistica Division (UNSD)

The Project for Ecosystem Services (ProEcoServ) is a GEF-funded umbrella project aiming at piloting the bundling of ecosystem services and the integration of ecosystem services approaches into resource

management and decision-making 


\section{Resilience}

assessment

Assessing resilience in social-ecological systems: Workbook for practitioners (Revised version 2.0)

Assessing resilience in social-ecological systems - A workbook for scientist

Social-ecological Inventory Workbook - Supplement to the workbook for Practitioner

Applying Resilience thinking

Principles for Building Resilience: Sustaining Ecosystem Services in Social-Ecological Systems

Community and

Participatory

Assessment

Bio-cultural Resilience Tool

Community Conservation Resilience Initiative

Participatory mapping and management partnership, with links to many initiatives on mapping

Eco-cultural mapping, African Biodiversity Network website and GAIA

Maps for traditional knowledge - Technical Centre for Agricultural and Rural Development (CTA)
Resilience

Alliance

Resilience

Alliance

Resilience

Stockholm Resil-

ience Centre

http://www.stockholmresilience.org/21/

research/research-news/2-19-2015-

applying-resilience-thinking.html

http://www.resalliance.org/index.php/

resilience_assessment

published by Cambridge University Press

https://bioculturalresilience wordpress.com/ about/founding-partners/

http://globalforestcoalition.org/wp-content/ uploads/2014/05/CCR-Initiative-methodologyApril-2014-copy.pdf

www.pmmpartnership.com

http://www.gaiafoundation.org/

http://www.cta.int/en/article/2014-10-11/ maps-for-traditional-knowledge-n-bringingthe-3rd-dimension-to-the-negotiating-tablemedia-release.html 


\begin{tabular}{|c|c|c|c|c|c|c|}
\hline Issue & Name process publications & Authors & Affiliation & Year & Address/Link & Comment \\
\hline \multicolumn{7}{|c|}{$\begin{array}{l}\text { Related tools and } \\
\text { approaches }\end{array}$} \\
\hline & Ecosystem Approach & & & & http://www.cbd.int/ecosystem/ & \\
\hline & $\begin{array}{l}\text { Rapid Rural Appraisal (RRA) Participatory rural appraisal } \\
\text { (PRA) }\end{array}$ & & & & $\begin{array}{l}\text { http://www.iisd.org/casl/caslguide/ } \\
\text { RapidRuralAppraisal.htm; }\end{array}$ & \\
\hline & The Sustainable Livelihoods Approach (SLA), for example: & & & & http://www.ifad.org/sla/ & \\
\hline & $\begin{array}{l}\text { Power Analysis, for example: Power Analysis - A Practical } \\
\text { Guide, Jethro Petit }\end{array}$ & & Sida & 2013 & $\begin{array}{l}\text { http://www.sida.se/Publications/Import/pdf/ } \\
\text { sv/Power-Analysis-A-Practical-Guide_3704.pdf }\end{array}$ & \\
\hline & Power Analysis - Experiences and Challenges & Helena Bjuremalm & Sida & 2006 & $\begin{array}{l}\text { http://www.sida.se/Svenska/Om-oss/ } \\
\text { Publikationsdatabas/Publikationer/2006/juni/ } \\
\text { Power-Analysis---Experiences-and-Challenges/ }\end{array}$ & \\
\hline ILK & $\begin{array}{l}\text { Connecting Diverse Knowledge Systems for Enhanced Eco- } \\
\text { system Governance: The Multiple Evidence Base Approach }\end{array}$ & & Ambio & 2014 & $\begin{array}{l}\text { http://www.stockholmresilience.org/ } \\
\text { download/18.3110ee8c1495db744326109/ } \\
\text { 1421247654519/Connecting+Diverse+ } \\
\text { Knowledge+Systems_MEB.pdf }\end{array}$ & \\
\hline ILK & $\begin{array}{l}\text { The Contribution of Indigenous and Local Knowledge } \\
\text { Systems to IPBES: Building Synergies with Science }\end{array}$ & & IPBES/UNESCO & 2013 & $\begin{array}{l}\text { unesdoc.unesco.org/images/ } \\
\text { 0022/.../225242E.pdf }\end{array}$ & \\
\hline ILK & $\begin{array}{l}\text { Potentials and pitfalls in exchange of knowledge systems in } \\
\text { cross-scale ecosystem assessments }\end{array}$ & & SwedBio/SRC & 2011 & & $\begin{array}{l}\text { Report from an informal expert meeting with repre- } \\
\text { sentatives of the International Indigenous Forum on } \\
\text { Biodiversity (IIFB), EU experts and scientists en- } \\
\text { gaged in TK and IPBES1 }\end{array}$ \\
\hline ILK & $\begin{array}{l}\text { IPBES/1/INF/5 Consideration of initial elements: recognising } \\
\text { indigenous and local knowledge and building synergies with } \\
\text { science }\end{array}$ & & IPBES & & IPBES.net & \\
\hline ILK & $\begin{array}{l}\text { IPBES/3/INF/2 - Update on deliverable } 1(\mathrm{c}) \text { ILK procedures } \\
\text { and approaches }\end{array}$ & & IPBES & & IPBES.net & \\
\hline ILK & $\begin{array}{l}\text { Ecological complexity, fuzzy logic, and holism in indigenous } \\
\text { knowledge }\end{array}$ & & Elsevier & & $\begin{array}{l}\text { www.sciencedirect.com/.../ } \\
\text { s0016328708001092 }\end{array}$ & \\
\hline \multicolumn{7}{|c|}{ Indicators } \\
\hline & The Biodiversity Indicators Partnership (BIP) & & & & $\begin{array}{l}\text { http://www.bipindicators.net/ } \\
\text { http://www.bipindicators.net/ } \\
\text { 2010bippublications }\end{array}$ & \\
\hline
\end{tabular}


http://www.bipindicators.net/

resource/aichipassport

The UNEP World Conservation Monitoring Centre UNEP-WCMC)

CBD Technical Series No. 58, Developing Ecosystem Service Indicators: Experiences and lessons learned from sub-globa assessments and other initiatives

CBD Technical Series No. 53, Biodiversity Indicators \& The 2010 Biodiversity Target: Outputs, experiences and lessons learnt from the 2010 Biodiversity Indicators Partnership,

The Ecosystem Service Indicators Database (ESID)

http://www.unep-wcmc.org http://www.cbd.int/doc/publications/ cbd-ts-58-en.pd

http://www.cbd.int/doc/publications/ cbd-ts-53-en.pdf

http://www.wri.org/
Comment

The Aichi Targets Passport - a publication of the B odiversity Indicators Partnership, BIP, provides annual updates for the global biodiversity indicators brought together by the BIP to monitor progress towards the Convention on Biodiversity's Strategic Plan for Biodiversity 2011-2020 and the underlying Aichi Biodiversity Targets. The passport is available as a smartphone app

This report synthesises experiences and approaches to measuring, mapping and monitoring ecosystem services worldwide. It draws on the experiences of a range of sub-global assessments, which have been conducted during and subsequent to the Millennium Ecosystem Assessment. The report is based on discussion and recommendations arising from international workshops held in 2009 and 2010, and its findings have contributed to the process of developing an indicator framework for the Aichi targets adopted by Parties to the CBD in Nagoya. It includes an annex of fact sheets describing examples of ecosystem of vice indicators taken from a range of asstessm ser-

Was created by the World Resources Institute to make ecosystem service metrics and indicators readily available for use in policy dialogues and decisions, in ecosystem assessments, and in natural resource management decisions. ESID is an online searchable database where users can find - and contribute - indicators that have been used to apply ecosystem services approaches or hold promise for doing so. Indicator descriptions and other supporting information about how the indicator has been or could be applied are also provided. To begin using ESID, visit the Indicators Overview page where you can browse, search and filter the entire collection of indicators. For further information see WRI 


\section{Issue}

Name process publications

Toolkit for the Indicators of Resilience in Socio-ecological

Production Landscapes and Seascapes

UNU-IAS, Bioversity International, IGES and UNDP (2014) Toolkit for the Indicators of Resilience in Socio-ecological Production Landscapes and Seascapes (SEPLS)

UNU-IAS Policy Report Indicators of Resilience in Socioecological Production Landscapes (SEPLS)

Indicators Relevant for Indigenous Peoples: A Resource

Community based monitoring and information system:

Ecosystem Service Indicators: A social-ecological system approach for generating relevant indicators for the CBD 2020 targets

\section{Inclusive wealt \\ Accounting, \\ Reporting and \\ Indicators}

Report by the Commission on the Measurement of Economic Performance and Social Progress

Inclusive Wealth Report 2012. Measuring progress toward sustainability

Inclusive Wealth Report 2014. Measuring progress toward sustainability

The State of Natural Capital: Towards a framework for measurement and valuation
Authors

Affiliation

http://satoyama-initiative.org/wp/

ploads/2014/11/TOOLKIT-X-

ma-initiative.org/en/

publication-toolkit-for-the-indicators-of-

resilience-in-socio-ecological-production-

landscapes-and-seascapes-sepls/

http://www.ias.unu.edu/resource_centre/

Indicators-of-resilience-in-sepls_ev.pdf

http://www.tebtebba.org/index.php/

content/123-indicators-relevant-for-

indigenous-peoples-a-resource-book

http://www.cbd.int/doc/press/2013/

pr-2013-10-12-8j-en.pdf

http://www.stockholmresilience.org/21/ publications/artiklar/2-9-2011-ecosystemservice-indicators-a-social-ecological-

systems-approach-for-generating-relevan dicators-for-the-cbd-2020-targets.html

Cambridge University Press. UNU-IHDP and UNEP http://www.ihdp.unu.edu/article/iw

UNEP

http://www.valuing-nature.net/news/2014/

unep-inclusive-wealth-report-2014

April, Natural Capital Committee, UK 
http://www.worldbank.org/en/topic/

environment/brief/environmental-economics-

natural-capital-accounting

Moving beyond GDP : how to factor natural capital into economic decision making (English)

Adjusted net saving - a proxy for sustainability

\author{
UNSTAT Experimental Ecosystem Accounting -
}

Wealth Accounting and the Valuation of Ecosystem Services (WAVES)

Ecosystem natural capital accounts: A Quick Start Package, CBD Technical Series No. 77

Towards a global map of natural capital: key ecosystem

Human Development Index

Happy Planet Index http://documents.worldbank.org/curated/

en/2012/06/16342172/moving-beyond-gdpen/2012/06/16342172/moving-beyond-g-g-

http://web.worldbank.org/WBSITE/

EXTERNAL/TOPICS/ENVIRONMENT/EXTEEI/

0,contentMDK:20502388 menuPK:1187778

pagePK:210058 piPK:210062 theSitePK: 408050,00.htm

http://unstats.un.org/unsd/envaccounting/ seea.asp http://unstats.un.org/unsd/ envaccounting/seearev/

Chapters/SEEA_EEA_v1.pd

http://www.wavespartnershiporg/

http://www.cbd.int/doc/publications/ cbd-ts-77-en.pdf

http://www.unep-wcmc.org/system/ dataset file fields/files/000/000/232/ original/NCR-LR_Mixed.pdf?1406906252

http://hdr.undp.org/en/statistics/hdi http://hdr.undp.org/en/data

http://www.happyplanetindex.org/
The System of Environmental-Economic Accounting (SEEA) Experimental Ecosystem Accounting describes the state of knowledge on accounting for ecosystems. It introduces an accounting framework that may be used to commence and support work on ecosystem accounting and to facilitate the exchange of experiences in the testing of various aspects of ecosystem accounting
The first Human Development Report introduced a new way of measuring development by combinin indicators of life expectancy, educational attainment and income into a composite human development index, the HDI

The HPI measures what matters: the extent to which countries deliver long, happy, sustainable lives for the people that live in them. The Index uses global data on life expectancy, experienced well-being and Ecological Footprint to calculate this 
projects_and_initiatives/biodiversity-

Conceptual and Methodological Framework for Evaluating finance-initiative/

the Contribution of Collective Action to Biodiversity

http://www.cbd.int/doc/meetings/cop/

cop-12/information/cop-12-inf-07-en.pdf

Conservation International, Metrics for Conservation and

Human Wellbeing

www.metricsci.org 



\section{Annex 3.}

\section{Examples of National bills and commitments, Regional and other Agreements (more information available in Excel files, available upon request from SEPA)}

Table 1: Examples of National bills and commitments

\begin{tabular}{|c|c|c|}
\hline Area / Name & Address/Link & Comment \\
\hline \multicolumn{3}{|l|}{ General-Global } \\
\hline \multicolumn{3}{|l|}{ Convention on Biological Diversity } \\
\hline \multicolumn{3}{|l|}{$\begin{array}{l}\text { Nagoya Protocol on access and benefit } \\
\text { sharing (CBD) }\end{array}$} \\
\hline \multirow{4}{*}{\multicolumn{3}{|c|}{$\begin{array}{l}\text { Convention on Access to Information, } \\
\text { Public Participation in Decision-making } \\
\text { and Access to Justice in Environmental } \\
\text { Matters (Aarhus Convention) }\end{array}$}} \\
\hline & & \\
\hline & & \\
\hline & & \\
\hline \multicolumn{3}{|l|}{$\begin{array}{l}\text { Convention on the Conservation of Mi- } \\
\text { gratory Species of Wild Animals } \\
\text { (Bonn Convention) }\end{array}$} \\
\hline \multicolumn{3}{|l|}{ Interstate Commission on Sustainable } \\
\hline \multicolumn{3}{|l|}{ Development } \\
\hline \multicolumn{3}{|l|}{$\begin{array}{l}\text { Convention on Wetlands of Interna- } \\
\text { tional Importance, especially as Water- } \\
\text { fowl Habitat (Ramsar Convention) }\end{array}$} \\
\hline $\begin{array}{l}\text { UN Declaration on the Rights of Indige- } \\
\text { nous Peoples }\end{array}$ & $\begin{array}{l}\text { http://www.un.org/esa/socdev/ } \\
\text { unpfii/documents/DRIPS_en.pdf }\end{array}$ & \\
\hline $\begin{array}{l}\text { ILO } 169 \text {. Convention concerning Indige- } \\
\text { nous and Tribal Peoples in Independent } \\
\text { Countries }\end{array}$ & $\begin{array}{l}\text { http://www.ilo.org/indigenous/ } \\
\text { Conventions/no169/lang--en/index.htm }\end{array}$ & Norway has ratified the convention \\
\hline \multicolumn{3}{|l|}{ European specific } \\
\hline \multicolumn{3}{|l|}{ Convention for the Protection of the } \\
\hline \multicolumn{3}{|l|}{ Marine Environment of the North-East } \\
\hline Atlantic (OSPAR Convention) & & \\
\hline
\end{tabular}




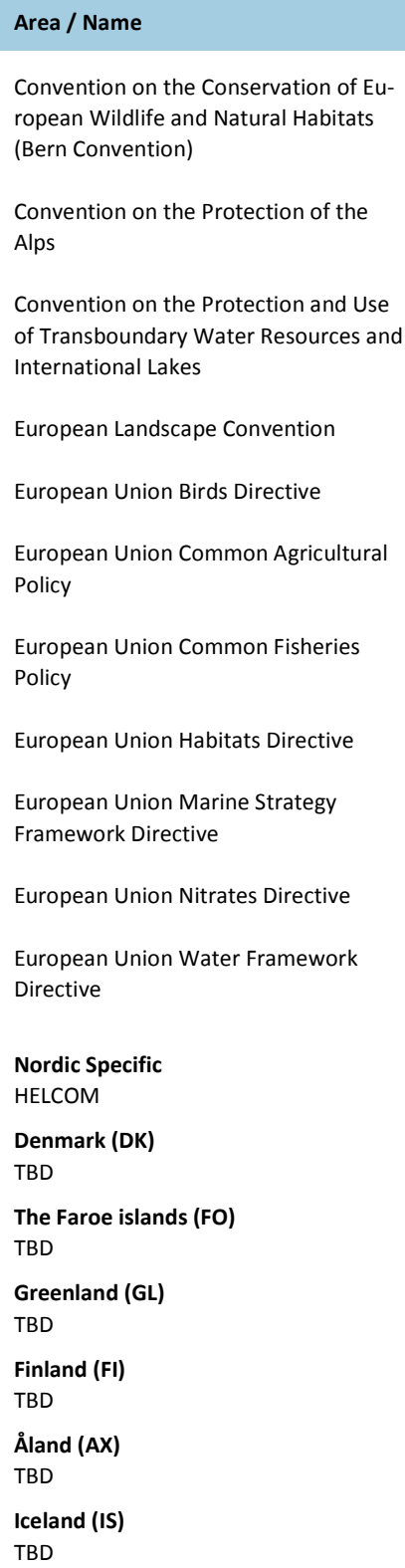

Convention on the Conservation of European Wildlife and Natural Habitats (Bern Convention)

Convention on the Protection of the Alps

Convention on the Protection and Use of Transboundary Water Resources and International Lakes

European Landscape Convention

European Union Birds Directive

European Union Common Agricultura Policy

European Union Common Fisheries

Policy

European Union Habitats Directive

European Union Marine Strategy Framework Directive

European Union Nitrates Directive

European Union Water Framework Directive

Nordic Specific

HELCOM

Denmark (DK)

TBD

The Faroe islands (FO)

TBD

Greenland (GL)

TBD

Finland (FI)

TBD

Åland (AX)

TBD

Iceland (IS)

TBD

\section{Norway (NO)}

Naturmangfoldsloven (2009) (Nature Diversity Act)

https://lovdata.no/dokument/ NL/lov/2009-06-19-100
The purpose of this Act is to protect biological, geological and landscape diversity and ecological processes through conservation and sustainable use, and in such a way that the environment provides a basis for human activity, culture, health and well-being, now and in the future, including a basis for Sami culture 


\begin{tabular}{|c|c|c|}
\hline Area / Name & Address/Link & Comment \\
\hline Planning and Building Act (rev 2009) & $\begin{array}{l}\text { https://lovdata.no/dokument/NL/lov/ } \\
2008-06-27-71 \text { ?q=plan+og+ } \\
\text { bygningsloven }\end{array}$ & $\begin{array}{l}\text { Several new instruments are included } \\
\text { to ensure that biodiversity considera- } \\
\text { tions and other important issues are } \\
\text { taken more fully into account in land- } \\
\text { use planning processes }\end{array}$ \\
\hline The Marine Resources Act & $\begin{array}{l}\text { https://lovdata.no/dokument/NL/lov/ } \\
\text { 2008-06-06-37?q=marine+ressurser }\end{array}$ & $\begin{array}{l}\text { The aim is to ensure sustainable and } \\
\text { economically profitable management of } \\
\text { wild living marine resources and genetic } \\
\text { material derived from them, and to pro- } \\
\text { mote employment and settlement in } \\
\text { Norway's coastal communities. Core el- } \\
\text { ements in the act are highly relevant to } \\
\text { maintaining biodiversity }\end{array}$ \\
\hline The Aquaculture Act & $\begin{array}{l}\text { https://lovdata.no/dokument/NL/lov/ } \\
\text { 2005-06-17-79?q=akvakultur }\end{array}$ & $\begin{array}{l}\text { Includes regulations on the ecological } \\
\text { impact of aquaculture }\end{array}$ \\
\hline $\begin{array}{l}\text { Strategy on Invasive Alien Species } \\
\text { (2007) }\end{array}$ & $\begin{array}{l}\text { https://www.regjeringen.no/ } \\
\text { globalassets/upload/md/vedlegg/ } \\
\text { planer/t-1460.pdf }\end{array}$ & \\
\hline \multicolumn{3}{|l|}{ Sweden (SE) } \\
\hline $\begin{array}{l}\text { Government Bill2013/14:141 - "A Swe- } \\
\text { dish strategy for biodiversity and } \\
\text { ecosystem services" (En svensk strategi } \\
\text { för biologisk mångfald och ekosystem- } \\
\text { tjänster Prop 2013/14:141) }\end{array}$ & $\begin{array}{l}\text { http://www.regeringen.se/ } \\
\text { rattsdokument/proposition/ } \\
\text { 2014/03/prop-201314141/ }\end{array}$ & \\
\hline $\begin{array}{l}\text { The Swedish environmental objectives } \\
\text { system with a generational goal and } 16 \\
\text { environmental quality objectives, and } \\
24 \text { milestone targets (Det svenska miljö- } \\
\text { målssystemet; består av ett generat- } \\
\text { ionsmål, sexton miljökvalitetsmål och } \\
\text { tjugofyra etappmål) }\end{array}$ & http://www.miljomal.se/ & \\
\hline $\begin{array}{l}\text { The Planning and Building Act (PBL) } \\
\text { governs the planning of land, water and } \\
\text { construction }\end{array}$ & $\begin{array}{l}\text { Swedish Code of Statutes } \\
\text { https://www.riksdagen.se/ }\end{array}$ & \\
\hline \multicolumn{3}{|l|}{$\begin{array}{l}\text { Naturvårdslag (1964:822) (Nature Con- } \\
\text { servation Act) }\end{array}$} \\
\hline $\begin{array}{l}\text { The Right of Public Access } \\
\text { (Allemansrätten) }\end{array}$ & $\begin{array}{l}\text { Chapter } 2 \text { Section } 18 \text { of the Swedish In- } \\
\text { strument of Government } \\
\text { http://www.swedishepa.se/ } \\
\text { Enjoying-nature/The-Right-of-Public- } \\
\text { Access/This-is-allowed/ }\end{array}$ & \\
\hline
\end{tabular}





\section{Annex 4.}

Examples of potential Strategic

Partners and Roster of Experts

(more information available in Excel

files, available upon request from SEPA) 
Table 1: Examples of potential Strategic Partners and Roster of Experts - Authorities and International Agencies/Institutions

Area Authority/Name Project $\quad$ Name Contact Address/Link $\quad$ Comment

General

TEEB - The Economics of Ecosystems and Biodiversity

Common International Classification of Ecosystem Services (CICES)

UN-SEEA

The UNEP World Conservation Monitoring Centre (UNEP-WCMC)

Sub-Global Assessment Network

Arctic Counci

European

MAES

ESMERALDA

Operationalisation of Natural Capital and Ecosysem Services, Openness

OPERAS

UK-NEA http://www.teebweb.org

http://cices.eu/

http://unstats.un.org/unsd/envaccounting/seea.asp

http://www.unep-wcmc.org

http://www.ecosystemassessments.net/

http://www.arctic-council.org/index.php/en/

http://biodiversity.europa.eu/maes

http://www-esmeralda-projectew/

http://www.openness-project.eu/

http://www.operas-project.eu/
The Common International Classification of Ecosystem Services (CICES) developed from the work on environmental accounting undertaken by the European Environment Agency (EEA). It supports their contribution to the revision of the System of United Nations Statistical Division (UNSD)

The Arctic Council consists of the eight Arctic States: Canada, Denmark (includin Greenland and the Faroe Islands), Finland, Iceland, Norway, Russia, Sweden and the United States. Six international organisations representing Arctic Indigenous Peoples have permanent participant status

Documents and literature in connection to MAES

ESMERALDA aims to deliver a flexible methodology to provide the building blocks for pan-European and regional assessments

OpenNESS aims to translate the concepts of Natural Capital (NC) and Ecosystem Services (ES) into operational frameworks that provide tested, practical and tailored solutions for integrating ES into land, water and urban management and decision-making. It examines how the concepts link to, and support, wider EU economic, social and environmental the concepts link to, and support, wider EU economic, social the concepts of ES and NC

OPERAs is a European research project which aims to bridge the gap between ecosystem science and practice. The project has 27 partners from academic institutions, consultancies and SMEs across Europe. The OPERAs team comprises scientists, researchers and practitioners from many disciplines, working together to establish

what constitutes good governance of ecosystems

The UK National Ecosystem Assessment (UK NEA) was the first analysis of the UK's natural environment in terms of the benefits it provides to society and continuing economic prosperity. From short questionn on WP 6 on shared values of ecosystem services (ES), focusing on cultural ES 
IPBES - Regional Assessment Europe and Central Asia (ECA)

The Pan-European Biodiversity Platform

Nordic

Nordregio

NordMap/Nordregio

Nordic Council of Ministers

Norden

Arctic Portal

Barents Protected Area Network (BPAN)

Conservation of Arctic Flora and Fauna (CAFF)

Denmark (DK)

Ministry of the Environment

De Økonomiske Råd (The Economic Councils)

The Danish Nature Agency

Danish Ministry of Environment

(I) currently preparing the regional and subregional assessment of biodiversity and ecosystem services in Europe and Central Asia (ECA), with the target subresions Western Europe, Eastern Europe and Central Asia, including an analysis of the current status, trends, future forrocasts, and expected impacts on human society (IPBES delivertus, trens, Centra Asia hosted by the Univity Centra Asta, hos ad by the Unversty of Be is me me administrative activities of the Regional ECA Assessment. The TSU will work very Closely with the three Co-Charrs of the ECA Assessment, the IPBES Secretariat in Bonn, Germ ny and he Bus or

http://unepineurope.org/index.php?option=com content\&view=article\&id=144:unep-to-provide-thesecretariat-for-the-pan-european-biodiversityplatform\&catid=72:un-environment-assembly

http://www.nordregio.se/

http://www.nordregio.se/System/News/

New-NORDMAP-web-mapping-tool-Create-shareand-print-maps/

\section{http://www.norden.org/en}

http://www.norden.org/en

http://www.arcticportal.org/

http://www.bpan.fi/

http://www.caff.is/
Interesting information about the region and also maps

NordMap is the name of a new Nordic web-mapping tool for demography, labour market and accessibility in the Nordic countries. With NordMap you can analyse local and regional development trends and create, share and print customised maps without any previous mapping or GIS experience

\section{Interesting information about the region and also maps}

Interesting information about the region and also maps

The Barents Protected Area Network (BPAN) has, with support from the Nordic Council of Ministers, analysed the system of PAs in the Barents regions. BPAN provides both analyses (essentially assessments) and recommendations that are highly relevant to a Nordic Assessment of Biodiversity and Ecosystem Services www.nst.dk

www.mfvm.dk 
Arctic general and arctic council, implementation agreement under

Bjørn Tirsgaard

\section{(1)}

Marine Strategy Framework Directive (EU), regional marine convention (OSPAR) (biodiversity)

Convention on Law of the Sea, GL and FO, HELCOM

Ane-Marie L. Rav

anlra@snt.dk

Focal point Nagoya Protocol under CBD (access and benefit-sharing of genetic resources (ABS)), Nordic Council of Ministers, EU biodiv.

strategy - MAES WG, UM steering group for ABS initiative Africa

Marine Strategy Framework Directive (EU), HELCOM

Sille Juhl Prang

sipra@nst.dk

Eva Juul Jensen

ejj@nst.dk

Tonny? $\quad$ Tonny@nst.dk

OSPAR

Christina F. Nielsen cfnie@nst.dk

CITES, agreement on water birds (AEWA) Bonn Convention (migratory species - CMS)

Int. forest agreement, sustainable wood and biomass, fight against illegal wood

Head of function for OSPAR, HELCOM, Marine Strategy Framework Directive, Arctic IMO etc.

Head of function for CBD incl. Nagoya Protocol, CITES, CMS, AEWA, EU biodiv. strategy, IPBES, Post 2015

Management Board officer for international work

Ballast Water Management Convention / marine invasive species UN International Maritime Organisation (IMO) and HELCOM-OSPAR

Marine Strategy Framework Directive, regional marine conventionSOSPAR and HELCOM, marine waste

nin@nst.dk

Christian Lundmark clj@nst.dk

Jensen

Ditte Mand $\varnothing$

diman@nst.dk Andreasen

asamu@nst.dk

Rikke Schaltz

rirsc@nst.dk

Ulrik Chr.

ucb@nst.dk

Berggreen

lomu@nst.dk

Søderberg

www.fve.fo

www.natur.gl

Greenland Institute of Natural Resources

http://naalakkersuisut.gl/en/Naalakkersuisut/ Departments/Udenrigsdirektoratet 
www.naalakkersuisut.g

http://naalakkersuisut.gl/en/Naalakkersuisut/ Departments/Fiskeri-Fangst-og-Landbrug

Ministry of Nature, Environment and Justice (GL)

Fishing Licence Inspection

(including hunting officers/game keepers) (GL):

Greenland Language Secretariat

KANUKOKA

Aarhus University, Institute of Bioscience

Finland (FI)

Ministry of the Environment

Ministry of Agriculture and Forestry

Ministry of Employment and the Economy

Ministry for Foreign Affairs of Finland www.um.fi/en

Ministry of Finance

Prime Minister's Office Finland kanslia

(Indicators and measuring of well-being)

Association of Finnish Local and Regional Authorities

Ministry of Justice, Finland

Ministry of Education and Culture

Ministry of Defence

Ministry of Social Affairs and Health

Ministry of Transport and Communications

Finnish Wildlife Agency
http://naalakkersuisut.gl/en/Naalakkersuisut/

Departments/Natur-Miljoe-og-Justitsomraadet/ Natur -Energi-og-Klimaafdelingen

http://dk.vintage.nanoq.gl/Emner/Erhverv/

Erhvervsomraader/Fiskeri/

Fiskerilicenskontrollen. aspx

http://www.oqaasileriffik.gl/en

kanukoka@kanukoka.gl

Tom Christensen http://bios.au.dk/en/about-bioscience/

www.ym.fi/en

www.mmm.fi/en

www.tem.fi/en

www.um.fi/en

www.vm.fi/en

www.vnk.fi/en

http://www.localfinland.fi/en/Pages/default.aspx

http://www.oikeusministerio.fi/en/index.htm

http://www.minedu.fi/OPM/?lang=en

http://www.defmin.fi/en

http://www.stm.fi/en/frontpage

http://www.lvm.fi/en/home

http://riista.fi/en/

\section{Comment}

Nette Levermann (NELE@nanoq.g)

Kalaallit Nunaanni Kommunit Kattuffiat (De Grønlandske Kommuners Landsforening)

\section{National IPBES panel members}

National IPBES panel members

National IPBES panel members

National IPBES panel members

National IPBES panel members

National IPBES panel members

National IPBES panel members

National IPBES forum (38-41 members including stakeholders etc)

National IPBES forum (38-41 members including stakeholders etc.)

National IPBES forum (38-41 members including stakeholders etc.)

National IPBES forum (38-41 members including stakeholders etc.)

National IPBES forum (38-41 members including stakeholders etc.)

National IPBES forum (38-41 members including stakeholders etc.) 
Area

Authority/Name Project

Statistics Finland

Metsähallitus in Ivalo/Inari

Finnish Sámi Parliament

Åland (AX)

Ålands landskapsregering (Åland Government)

The Åland environmental and health protection authority deals among other things with environmental permits

Åland Government

Ålands miljö- och hälsoskyddsmyndighet

ÅSUB -Statistics and Research Åland

Iceland (IS)

TBD

Norway (NO)

Norwegian Environment Agency

Norwegian Polar Institute

Directorate of Fisheries

Norwegian Agricultural Authority

Statistics Norway

Norwegian Agency for Development Cooperation

Norwegian Sami Parliament

Sweden (SE)

Swedish Environmental Protection Agency (SEPA) Naturvårdsverket

Swedish Board of Agriculture (Jordbruksverket)

Swedish Forest Agency (Skogsstyrelsen)

Swedish National Heritage Board (Riksantikvarieämbetet)
Name Contact

Address/Lin

http://www.stat.fi/index_en.html

http://www.metsa.fi/

http://www.samediggi.fi/index.php?lang=english

www.regeringen.ax

www.amhm.ax

www.asub.ax

www.miljodirektoratet.no

http://www.npolar.no/no/

http://www.fiskeridir.no/english

https://www.slf.dep.no/en/

http://www.ssb.no/

http://www.norad.no/en/front/

https://www.sametinget.no

http://www.naturvardsverket.se/

www.jordbruksverket.se

www.skogsstyrelsen.se

www.raa.se

\section{Comment}

National IPBES forum (38-41 members including stakeholders etc.)

Forest and park service of Finland

Aland Government; different departments for Health and Environment

(e.g. Environmental Agency) and for Trade and Industry (e.g. Agencies for Agriculture and Forestry)

Åland Environmental and Health Protection Authority, deals with Environmenta Permits, inter alia

The Official Statistic Authority of Åland 
Swedish Agency for Marine and Water Management (SWAM), Havs och vattenmyndigheten, HAV

SMHI , Swedish Meteorological and Hydrological Institute

SGU, The Geological Survey of Sweden, is the expert agency for issues relating to bedrock, soil and groundwater in Sweden

SCB, Statistics Sweden

Swedish Forest Agency

Swedish Board of Agriculture

Swedish Chemicals Agency (KEMI)

LM Lantmäteriet

Swedish Maritime Administration

Swedish National Board of Housing Building and Planning Boverket (BV)

\section{Sami Parliament}

Municipalitites (kommuner) such as Järfälla, Göteborg etc.

County councils and regions (landsting och regioner)

Swedish Association of Local Authorities and Regions (Sveriges Kommuner och Landsting, SKL)

www.havochvatten.se

http://www.smhi.se/en

http://www.sgu.se/en/

http://www.scb.se/en /

http://www.skogsstyrelsen.se/en/

http://www.jordbruksverket.se/

http://www.kemi.se/

http://www.lantmateriet.se/en/

http://www-sjofartsverketse/en/

http://www.boverket.se/

ttp://www.sametinget.se/englis
Presently looking at who owns the land as part of the assessment. In that way it is easier to link the biodiversity data to other social data and make more integrated assessments. http://www.scb.se/Statistik/_Publikationer/

They have also carried out a study to identify data sources

http://www.scb.se/statistik/_publikationer/MI1301_2013A01_BR_MI71BR1303.pdf

The Swedish Forest Agency is a statistical agency and is responsible for three fores statistical areas, "Forestry production", "Employment in forestry" and "Environmen and social values in forestry"

Swedish Board of Agriculture is the authority responsible for Sweden's official statistics as regards the agricultural sector and aquaculture

KEMI is a government agency working to control chemicals

LM Lantmäteriet provides society with maps, images and other fundamental geographic information

BV is the national agency for planning, the management of land and water re-

sources, urban development, building and housing. Boverket monitors the function of the legislative system under the Planning and Building Act and related legislation and proposes regulatory changes

The Sami Parliament is a blend of a publicly elected parliament and a State administrative agency with limited and legally regulated tasks. There is a built-in conflict between the Samis' desire for increased independence and the government's restrictiveness and agency regulation 
Man and Biosphere reserves (MAB):

E.g. Kristianstads Vattenrike Biosphere Reserve

County administrative boards (länsstyrelser)

\section{Table 2: Examples of potential Strategic Partners and Roster of Experts - NGOs and Indigenous and Local Knowledge organisations and persons}

$\begin{array}{lllllll}\text { Area } & \text { Organisation } & \text { Project } & \text { Contact or Resource person } & \text { Title Address/Link } & \text { Comment }\end{array}$

General

IUCN

WWF

EALAT .The International Centre for Reindeer Husbandry

Nordic
Friluftsrådet (Outdoor Recreation Council)

Nordiska kulturlandskapsförbundet (Nordic cultura landscape association) http://reindeerherding.org/tag/ ealat/

https://eloka-arctic.org/ https://eloka-arctic.org/sites/ eloka_workshop_program _nov2011.pdf content/uploads/2014/12/Nordicleaflet-2013-2016.pdf

http://kulturlandskab.org eloka-arctic.org/files/documents/

http://www.norskfriluftsliv.no/wp
The International Centre for Reindeer Husbandry (ICR)

was established by the Norwegian Government in 2005 in Kautokeino, as a contribution to the unique internationa cooperation of circumpolar reindeer herding peoples. IC is an independent professional unit, with its own board and budget. Its core funding is provided by the Norwegian Government through annual grants from the budget of the Ministry of Reform and Government Administration

Arctic ELOKA facilitates the collection, preservation, exchange, and use of local observations and knowledge of the Arctic. ELOKA provides data management and use support, and fosters collaboration between resident Arctic experts and visiting researchers 
Area Organisation

Samerådet (Sami Council)

Denmark (DK)

Det eokologiske råd (Ecological Council)

\section{Faroe islands}

(FO)

Grindamannafelagið

Færøernes Fugleforening, FFFF

Greenland (GL)

Inuit Circumpolar Council

Association of Fishers and Hunters in Greenland (KNAPK)

KANUNUPE (National association of settlements) (GL)

PISUNA-project

Upernaviarsuk Experimental Farm (including sheepherder school) (GL)

Spare-time hunters/fishers (organized in TPAK)

Finland (FI)

Finnish Association for Nature Conservation (FANC)

BirdLife Finland
Contact or Resource person

gunn-britt@retter.no

\section{Address/Link}

http://www.samicouncil.net/

?deptid=1116

www.ecocouncil.dk

http://www.92grp.dk/index

php?option=com_content\&

view $=$ article\&id $=2 \& \mid$ temid $=6$

Ólavur Sjúrđarberg

olavur.sjurdarberg@skulin.fo

http://www.inuit.org/

http://www.knapk.g//

index.php?id=10\&L=2

http://www.qaasuitsup.gl/

da-DK/Om-kommunen/

Pisut-News/2013/9/

17_09_2013_kanunupe

www.pisuna.org

http://www.nunalerineq.gl/

english/uperna/index-uperna.htm

http://www.sll.fi/site-actions/ English

http://www.birdlife.fi/english/ index.shtml
Comment

A Danish NGO. The main objective is to promote sustainable development where environmental concerns, socia justice and human well-being are the main focal points

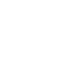

individual Natural Resource Councils 
Central Union of Agricultural Producers and Forest Owners (MTK)

Uarctic EALAT institute

\section{Snowchange cooperative}

Aland (AX)

Ålands Natur och Miljö (Åland Nature and Environment)

Ålands Producentförbund (Åland Producers' Association)

Ålands Skogsvårdsförening (Åland Forest Conservation Association

\section{Ålands Fågelskyddsförening}

(Åland Bird Protection Association)

Iceland (IS)

Landsbyggđin lifi

Norway (NO)

ForUM for Utvikling og Miljø (Forum for Development and Environment)

International Centre for Reindeer Husbandry

Valdres Nature- and culturepark (Valdres Nature and Culture Park) http://www.naturochmiljo.fi/ malgrupper/english/

http://wwf.fi/en/

http://www.mtk.fi/en GB/

Katharina.Sparstad@valdres.no>

The Finnish Society for Nature and Environment (FSNE) in Swedish Natur och Miljö, is a national environmental citizens' organisation (ECO)

http://reindeerherding.org/

projects/uarctic-ealat-institute/

Sromi museum SIIDA tero.mustonen@snowchange.org

petra@natur.ax

henry.lindstrom@landsbygd.ax

torbjorn.bjorkman@landsbygd.ax

\section{k.aland@yahoo.com}

Stefanía Gísladótti

disagisla@islandia.is

http://www.forumfor.no/

http://www.landsbygd.ax/ producentforbundet/

http://www.landsbygd.ax/

http:// skogsvardsforeningen/svf-om-oss/

www.fagelskyddsforeningen.ax

\section{Ornithologist Association in Åland}

Consists of approx. 50 members including WWF, Sabima, Regnskogfondet, Bellona

Valdres Nature- and culturepark. We are now mapping all the active summer farms in the region incl. culture herritage, rassland areas and in the rel paths. Valdes folk age, grassland areas and animal paths. Valdres folk museum ins ork gst, Loken, par

Bellona 
Regnskogfondet (Rainforest Foundation)

Sabima

WWF

Sweden (SE)

Small scale farmers association in Swede

Swedish Archipelago Farmers

The Swedish Association for Transhumance and

Pastoralism

Archipelago Foundation (Skärgårdsstiftelsen)

Uppland Foundation (Upplandsstiftelsen)

Västkuststiftelsen (West Coast Foundation)

Sami Parliament (Sametinget)

Swedish Sami Association

(Svenska Samernas Riksförbund), SSR

Riksorganisationen Same Ätnam

(National Sami Land Organisation) (RSÄ)

WWF Sweden

Swedish Society for Nature Conservation

(Naturskyddsföreningen)

Nature \& Youth Sweden (Fältbiologerna)

Various Baltic Sea network

Federation of Swedish Farmers

(Lantbrukarnas riksförbund, LRF)

Forest owner associations (skogsägarföreningar):

Södra, Mellanskog Norrskog and

Norra Skogsägarna 


\begin{tabular}{|c|c|c|c|c|c|c|}
\hline \multirow[t]{6}{*}{ Area } & Organisation & Project & Contact or Resource person & Title & Address/Link & Comment \\
\hline & $\begin{array}{l}\text { Swedish Association for Hunting and Wildlife Man- } \\
\text { agement (Svenska Jägareförbundet) }\end{array}$ & & & & & \\
\hline & BirdLife Sverige (Sveriges Ornitologiska Förening) & 13. & 14. & & & \\
\hline & $\begin{array}{l}\text { Swedish Mycological Society } \\
\text { (Sveriges Mykologiska Förening) }\end{array}$ & & & & & \\
\hline & $\begin{array}{l}\text { Swedish Botanical Society } \\
\text { (Svenska Botaniska Föreningen) }\end{array}$ & & & & & \\
\hline & $\begin{array}{l}\text { Swedish Bioenergy Association } \\
\text { (Svenska Bioenergiföreningen, Sve-Bio) }\end{array}$ & 16. & 17. & & & \\
\hline
\end{tabular}

Table 3: Examples of potential Strategic Partners and Roster of Experts - Private Sector

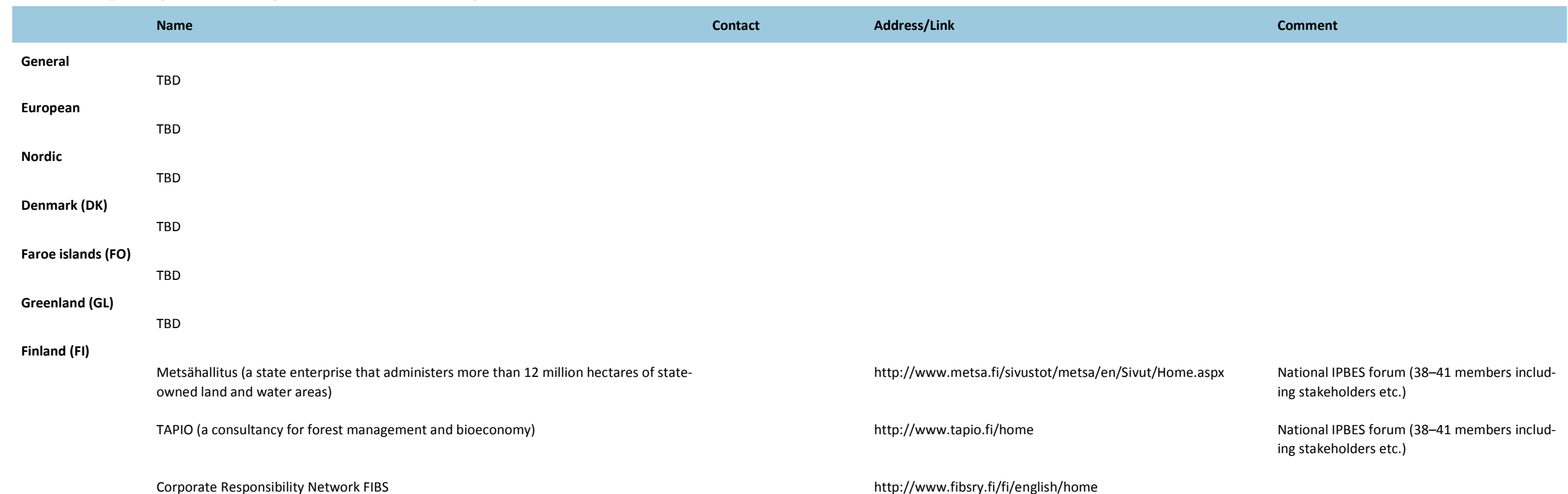


Åland (AX)

Forestry Companies (e.g. Skogen Ab)

Agricultural companies (e.g. ÅCA Ab, Ab Lantbruk, W.J. Dahlmans ab)

Aquaculture companies (e.g. Ålands Fiskförädling)

Iceland (IS)

TBD

Energy sector, incl. Statoi

Aquaculture

Agriculture

Forestry

Transport sector

NINA

Landscape Architecture and Spatial Planning (ILP)

Sweden (SE)

LRF

Forestry companies (e.g. SCA)

Mining companies (e.g. LKAB)

Agricultural companies (e.g. Arla, Lantmännen)

Aquaculture companies 



\section{Annex 5.}

Potential Nordic Hubs, contributing to sub-assessments of the Nordic Assessment of Biodiversity and Ecosystem Services (more information available in Excel files, available upon request from SEPA) 
Table 1: Potential Nordic Hubs, contributing to sub-assessments of the Nordic Assessment of Biodiversity and Ecosystem Services (more information available in Excel files, available upon request from SEPA)

\begin{tabular}{|c|c|c|c|c|}
\hline Area & Affiliation & Name contact person & Address/Link & Comment \\
\hline \multicolumn{5}{|c|}{ Nordic } \\
\hline & TBD & & & \\
\hline \multicolumn{5}{|c|}{ Denmark (DK) } \\
\hline & Nature Agency & Mette Gervin Damsgaard & Haraldsgade 53,DK- 2100 København & $\begin{array}{l}\text { Node under establishment, presently working group consists of Prof. Carsten Rahbek, Copenhagen } \\
\text { University, Prof. Niels-Christian Svenning, Aarhus University, Assoc. Prof. Eva Roth, University of } \\
\text { Southern Denmark }\end{array}$ \\
\hline \multicolumn{5}{|c|}{ Faroe islands (FO) } \\
\hline & TBD & & & \\
\hline \multicolumn{5}{|c|}{ Greenland (GL) } \\
\hline & TBD & & & \\
\hline \multicolumn{5}{|c|}{ Finland (FI) } \\
\hline & $\begin{array}{l}\text { SYKE (The Finnish Environ- } \\
\text { ment Institute) }\end{array}$ & & http://www.syke.fi/en-US/SYKE_Info & $\begin{array}{l}\text { The Finnish Environment Institute (also known as SYKE, after the Institute's Finnish acronym) is both } \\
\text { a research institute, and a centre for environmental expertise. SYKE forms part of Finland's national } \\
\text { environmental administration, and mainly operates under the auspices of the Ministry of the Envi- } \\
\text { ronment, although the Institute's work related to water resources is supervised by the Ministry of } \\
\text { Agriculture and Forestry. We have the skills, ambition and courage to open new avenues for improv- } \\
\text { ing the environment }\end{array}$ \\
\hline
\end{tabular}

Åland (AX)

TBD

Iceland (IS)

TBD

Norway (NO)

The Norwegian Institute

for Nature Research (NINA)

Sweden (SE)

BECC - Biodiversity and

Ecosystem services in

Changing Climate

Lund University and Uni- http://www.nina.no

http://www.becc.lu.se/ logical research, with broad-based expertise on the genetic, population, species, ecosystem and landscape level, in terrestrial, freshwater and coastal marine environments

BECC is a strategic research area between Lund University and University of Gothenburg comprising more than 200 researchers. Together we work for a better understanding of the impacts of climate change and land use decisions on terrestrial ecosystems and biodiversity, addressing the conse-

quences of ecosystem changes for human beings and socio-economic systems. BECC is funded by the Swedish Government 
Area Affiliation

The Swedish Biodiversity Centre (CBM) http://www.slu.se/en/collaborative-centres-and-projects/ swedish-biodiversity-centre1/

http://www.stockholmresilience.org/21/about.htm

http://www.su.se/ostersjocentrum/english/
Comment

The Swedish Biodiversity Centre (CBM) has the task of initiating, conducting and co-ordinating policyrelevant research on the complex interaction between biological diversity and societal development. CBM is also expect bly CBM a bly. CBM a th stake ho eraton wh stak internationally. CBM competencies range from ecology and conservation biology to anthropology, law, politcal science and history. CBM was established by a decision of the Swedish Government in 1994 and is a joint venture between the Swedish University of Agricultural Sciences (SLU) and Uppand sustainable use of biological diversity is located at CBM. http://www.naptek.se/

swedish National Programme on local and traditional knowledge related to Conservation and Sustainable Use of Biological Diversity. A government assignment between 2006-2012 to CBM in order to contribute to Sweden's implementation of Article 8(j) of the CBD and from 2013 funded on annua project basis by the Swedish Environmental Protection Agency

Stockholm Resilience Centre advances research on the governance of social-ecological systems with special emphasis on resilience - the ability to deal with change and continue to develop. The centre is a joint initiative between Stockholm University and the Beijer International Institute of Ecological Economics at the Royal Swedish Academy of Sciences

Stockholm University Baltic Sea Centre's mission is to strengthen significant marine activity that involves over ten different Departments at the University. A combination of experts and communicators who collaborate with a wide network of marine scientists to improve the knowledge about the Baltic Sea and help society manage its marine environmental problems 

Annex 6. Examples of possible funding sources 
Table 1: Examples of possible funding sources

Name Address/Link

General

European

Horizon2020

http://ec.europa.eu/

programmes/horizon2020/

LIFE

Nordic

$\begin{array}{ll}\text { Nordforsk } & \text { http://www.nordforsk.org/en } \\ \text { Nordic Joint Committee } & \text { http://nkj.nordforsk.org/no } \\ \text { for Agricultural and } & \\ \text { Food Research } & \end{array}$

Nordic Forest Research $\quad$ http://www.nordicforestresearch.org/
Comment

http://ec.europa.eu/

NKJ Announces a Call for Networking Activities in 2016-217

Deadline for application submission is Tuesday, September 15 at 12:00 CET.

Who can apply?

Researchers at research institutions in Denmark, Finland, Iceland, Norway, Sweden, Faroe Islands, Greenland and Åland are eligible to apply. Stakeholders can be involved, but cannot be main applicants.

The aim of the NKJ network call is to:

- increase North European regional synergy within agriculture and food research $(*)$

- establish better contact between the agriculture and food research $(*)$ communities in the Nordic countries

- strengthen North European agriculture and food research(*) and networking

(*) Including animal health and welfare and reindeer husbandry.

Scope

The applications are expected to contribute to the strategic goals of the NKJ and to promote competitiveness and innovativeness of

Nordic countries.

NKJ will in this strategy period, 2015-2018, focus on three thematic focus areas: climate change, globalisation and the transition to the bio-economy.

\section{Economic framework}

Network grants are for maximum 2 years. The total budget for the call is at least NOK 1,000,000. The maximum applied amount per network should be approx. NOK 250,000 . A self-financing component of at minimum $50 \%$ of the total budget of the network is required http://nkj.nordforsk.org/no/forskning/utlysninger/nkj-announces-a-call-for-networking-activities-in-2016-217

OPEN CALL - SNS Research Projects to start in 2016

SNS announces a call for SNS research projects to start in 2016. Projects should relate to the prioritised themes of the SNS strategy. SNS wishes to initiate projects which focus on "Forestry within bioeconomy, climate, and social-aspects" that are key elements in both, national, regional and EU strategies.

Timeline of Call and Application period:

The call will be announced on Wednesday 17th June 2015

Deadline for applications is 15th September 2015 at midnight CET.

Successful applicants will be notified in December 2015 and financing will start in January 2016.

Call description 
SNS supports research projects that focus on forests and forestry in the Nordic region. Support may be granted to research collaboration with a duration of no more than three years. Support from SNS is normally based upon a co-ordination of on-going national research. - The application is open to participants from the Nordic and Baltic countries, with adjacent areas. At least three Nordic countries should participate in each project.

- All SNS projects include a national co-financing of at least $67 \%$, with SNS funding a maximum of $33 \%$ of the project.

- Projects typically apply for SEK 200,000-SEK 500,000/year from SNS and 3-5 projects will be financed.

- SNS takes into account gender equality when evaluating the applications, having an overall goal of 40 to $60 \%$ representation in all of SNS activities.

- Projects should relate to the prioritised themes of the SNS strategy. SNS wishes to initiate projects that focus on "Forestry within bioeconomy, climate, and social aspects", which is a key element in national, regional and EU strategies.

http://www.nordicforestresearch.org/calls/research-projects/

Denmark (DK)

\section{Nordea}

\section{Bikube Fonden}

15 juni Fonden

Aage V. Jensen

Villum og Velux fonden

Faroe islands (FO)

$$
\text { TBD }
$$

Greenland (GL)

\section{Finland (FI)}

TBD
Academy of Finland

Tekes - the Finnish

Funding Agency for

Innovation

Maj and Tor Nesslingin

Foundation

Kone Foundation

Jenny and Antti Wihuri

Foundatio

Emil Aaltonen Founda-

tion www.nordeafonden.dk

\section{bikubefonden.dk}

www.15junifonden.dk

www.avjf.dk

vwww.veluxfondene.dk http://www.aka.fi/en/

http://www.tekes.fi/en/tekes/

$h t t p: / / w w w . n e s s l i n g . f i / ? l a n g=e$

http://www.koneensaatio.fi/en/

http://www.wihurinrahasto.fi/ foundation.html

http://www.emilaaltonen.fi/eng.htm

The Academy of Finland's mission is to fund high-quality scientific research, provide expertise in science and science policy, and strengthen the position of science and research. We are an agency within the administrative branch of the Finnish Ministry of Education, Science and Culture

Tekes is the most important publicly funded expert organisation for financing research, development and innovation in Finland. We boost wide-ranging innovation activities in research communities, industry and service sectors

Kone Foundation grants are awarded for research in the humanities, social sciences, for environmental research and for artistic research. Grants are also awarded for popularising reseach and for art and culture projects

Jenny and Antti Wihuri Foundation is a private, Finnish cultural foundation and was established in 1942 by a sea captain, shipowner and industrialist, Antti Wihuri, and his wife Jenny

The Emil Aaltonen Foundation, founded by the industrialist and philanthropist Emil Aaltonen in 1937, supports academic research by providing grants 
Åland (AX)

TBD

Iceland (IS)

Norway (NO)

Sweden (SE)

$$
\text { TBD }
$$

Formas - (Nordic

cooperations)

Formas - Communica-

tion projects

Formas - Conferences and workshops workshop

Vetenskapsrådet - Kon-

Research Council - Cor

ference contributions)

MISTRA

http://www.formas.se/sw/

http://formas.se/sv/finansiering/

varabidrag/konferensbidrag.4.

http://www.mistra.org/ http://formas.se/sv/finansiering/ utlysningar/konferenser-och-

Internationellt/Nordiska-samarbeten/ utlysningar/kommunikationsprojekt

lications: 1 September 2015

Last date for applications: 1 Septemb

Communication projects may be concerned with development of popular-science publications, exhibitions, conferences, seminars, film and video productions, digital products or other popular-science activities. Formas welcomes small problems, from approx. SEK 25,000 medium-sized projects around SEK 80,000 and larger communication projects

Applications may be submitted continuously, and the Formas Research Councils makes decisions.

Last date for applications $1 / 6$ decision date $16 / 6$
Last date for applications $6 / 8$ decision date $22 / 9$

Last date for applications $6 / 8$ decision date $22 / 9$

Formas invites applications for grants towards the costs of arranging conferences and workshops (referred to below as meetings) in its areas of responsibility. The meeting must attain high scientific quality, which is to be ensured by a scientific committee, which must exis and be stated in the application in addition to the organising committee. Priority is given to meetings arranged in Sweden. The grant can cover the costs of travel and accommodation for a limited number of, primarily, foreign participants. Funds from Formas can also represent grants towards organising costs (e.g. meeting premises).

Guide values for the size of the grant are up to SEK 200,000 for a larger conference (more than 200 participants) and up to SEK 30,000 for a smaller workshop (fewer than 30 participants).

http://vr.se/forskningsfinansiering/

3cbb1ce134a644c01380009308 htm

Last date for applications 9 September 2015 


\section{Annex 7. IPBES processes}

Information in this annex is mainly based on material under IPBES.net

\section{Box 1. IPBES goals, functions, objectives and deliverables}

IPBES goals: strengthen the science-policy interface for biodiversity and ecosystem services for the conservation and sustainable use of biodiversity, long-term human well-being and sustainable development.

IPBES functional approach: strengthen the science-policy interface at all levels through:

- Knowledge generation.

- Assessments of various geographic and thematic scope.

- Identified policy support tools.

- Addressing identified capacity building and catalysing financial support.

The Objectives (and deliverables) of IPBES are

Objective 1 - Strengthen the capacity and knowledge foundations of the sciencepolicy interface to implement key functions of the Platform:

- Deliverable 1(a): Priority capacity building needs to implement the Platform's work programme matched with resources through catalysing financial and in-kind support.

- Deliverable 1(b): Capacities needed to implement the Platform's work programme developed.

- Deliverable 1(c): Procedures, approaches and participatory processes for working with indigenous and local knowledge systems.

- Deliverable 1(d): Priority knowledge and data needs for policymaking addressed through catalysing efforts to generate new knowledge and networking.

Objective 2 - Strengthen the science-policy interface on biodiversity and ecosystem services at and across subregional, regional and global levels: 
- Deliverable 2(a): Guide on production and integration of assessments from and across all scales.

- Deliverable 2(b): Regional/subregional assessments on biodiversity and ecosystem services.

- Deliverable 2(c): Global assessment on biodiversity and ecosystem services.

Objective 3 - Strengthen the science-policy interface on biodiversity and ecosystem services with regard to thematic and methodological issues:

- Deliverable 3(a): Thematic assessment of pollinators, pollination and food production.

- Deliverable 3(b): Thematic assessments: (i). Thematic assessment on land degradation and restoration (ii). Thematic assessment on invasive alien species and their control (iii). Thematic assessment on sustainable use and conservation of biodiversity and strengthening capacities and tools.

- Deliverable 3(c): Policy support tools and methodologies for scenario analysis and modelling of biodiversity and ecosystem services based on a fast track assessment and a guide (by August 2015).

- Deliverable 3(d): Policy support tools and methodologies regarding the diverse conceptualization of values of biodiversity and nature's benefits to people including ecosystem services based on an assessment and a guide.

Objective 4 - Communicate and evaluate Platform activities, deliverables and findings:

- Deliverable 4(a): Catalogue of relevant assessments.

- Deliverable 4(b): Development of an information and data management plan.

- Deliverable 4(c): Catalogue of policy support tools and methodologies.

- Deliverable 4(d): Set of communication, outreach and engagement strategies, products and processes.

- Deliverable 4(e): Reviews of the effectiveness of guidance, procedures, methods and approaches to inform future development of the Platform.

See further at: http://ipbes.net/ 


\section{Box 2. Guide on the production and integration of assessments}

IPBES2 requested the MEP, the Bureau and a task-specific expert group to produce a guide on the production and integration of assessments from and across all levels (Decision IPBES-2/5). A draft guide has been produced (IPBES/3/INF/4;) and will probably be adopted by IPBES4. The draft contains the following sections and chapters:

- I: Addressing Conceptual issues.

- The IPBES Conceptual Framework and how to use it.

- IPBES assessments across scales.

- II: Applying the IPBES Assessment Processes.

- The IPBES assessment process.

- Using Uncertainty Terms.

- III: Use of Methodologies in Assessments.

- Values.

- Role of scenarios and models in assessment and decision making.

- Indigenous and Local Knowledge.

- IV: Identifying and Addressing Data, Information and Knowledge Resources and Gaps.

- Data.

- Knowledge Gaps.

- Biodiversity and Ecosystem Service Indicators.

- V: Enhancing the utility of assessments for decision makers and practitioners.

- Policy support tools and methodologies.

- Communication and stakeholder engagement.

- VI: Strengthening Capacities in the Science - Policy interface.

- Identifying and addressing Capacity Building Needs through Assessments.

The guide is not a formal set of rules, but it will be used by IPBES assessment teams to assist in producing thematic, global, regional and subregional assessments. It is hence important for a Nordic assessment to consider the guidance given in the document. 


\section{Box 3. Data and information management plan under IPBES}

A task force on knowledge and data has been established by the Plenary (Decision IPBES-2/5). The Secretariat and the task force have produced a short-term general data and information management plan (Decision IPBES-3/1, Annex II). The data and information management plan is intended to ensure access, in the future, both to the Platform's outputs and to the knowledge, information and data needed for their realisation. This is important in respect of both the transparency and the replicability of findings and is therefore a key issue for the credibility of the Platform. Among the deliverables from the implementation of the plan are:

- Data and metadata guidelines (June 2015).

- Principles for handling knowledge gaps and uncertainty (June 2015).

- A web-based discovery and access platform, building on a network of relevant initiatives and institutions (December 2015).

- Long-term collaboration and partnerships in place to provide access to existing data and information needed to support Platform (December 2015).

Principles that will guide implementation of the plan includes:

- Quality and security.

- Building knowledge through partnerships.

- Accessibility.

- Diverse disciplines and knowledge systems.

- Open science.

In addition to the data and information management plans mentioned above, the task force has also been asked to develop a long-term knowledge, information and data (KID) strategy. The outline of the knowledge, information and data (KID) strategy may offer additional information about what is expected from the Nordic assessment in terms of data and information management, to comply with IPBES rules of procedure. 


\section{Box 4. IPBES Scenario analysis and modelling}

Under IPBES an Expert Group is working on Deliverable 3(c): Policy support tools and methodologies for scenario analysis and modelling of biodiversity and ecosystem services. The fast track assessment of methodologies for scenario analysis and modelling of biodiversity and ecosystem services is important for guiding the use of such methodologies in all the Platform's work to ensure the policy relevance of its deliverables. Scenarios and models, including those based on participatory methods, have been identified as policy support tools and methodologies that can help decision makers to identify potential impacts of different policy options. Based on the findings of the methodological assessment, this deliverable will result in an evolving guide, followed by efforts to promote methods for the use of different types of knowledge and catalyse the development of databases, geospatial data, tools and methodologies for scenario analysis and modelling.

\section{Box 5. Indigenous and local knowledge systems}

A task force on indigenous and local knowledge (ILK) systems has been established by the Plenary (Decision IPBES-2/5). Draft procedures for and approaches to working with ILK are being developed by the task force, MEP and the Bureau for approval by IPBES4. Progress was reported at IPBES3 (IPBES/3/INF/2, appended file 10), including a preliminary guide (in Annex 2 of the document) on ILK approaches and procedures that will be used on a pilot basis in ongoing thematic and regional assessment (Decision IPBES-3/1). The draft preliminary approaches and procedures for working with indigenous and local knowledge are very brief and general, but highly relevant to the Nordic assessment.

\section{Approaches}

- Putting indigenous peoples and local communities and their places first.

- Finding mutual goals, benefits and benefit-sharing.

- Recognising and supporting rights and interests.

- Recognising and respecting diverse world views underpinning ILK systems.

- Establishing mutual trust and respect and an equitable intercultural space for dialogue.

- Ensuring free, prior and informed consent (FPIC).

- Recognising and respecting intellectual and cultural rights (ICR).

- Practising reciprocity, giving back and capacity building.

- Ensuring culturally appropriate storage of and access to information.

- Utilising formal and informal agreements and statements. 
Procedures

- Mobilising ILK holders and ILK researcher/practitioners through networks.

- Mobilising ILK holders with appropriate techniques, methods and tools.

- Mobilising participatory approaches to support indigenous and local knowledge and practice contributions.

- Convening local to global dialogue workshops during diverse phases of IPBES assessments.

- Recognising "community": understanding social structures and identifying groups or individuals with specialised knowledge.

- Considering gender and gender-specific knowledge.

- Supporting local studies, multiple scales and cross-scale linkages.

- Respecting ILK systems' validation procedures.

- Building dialogue addressing uncertainty between ILK and science.

- Implementing the work with ILK in assessments of IPBES through a dynamic interactive cycle.

Box 6. Guide regarding diverse conceptualisation of multiple values of nature and its benefits, including Biodiversity and ecosystem functions and services (|Deliverable $3 \mathrm{~d}$ )

The assessment of tools and methodologies regarding multiple values of biodiversity to human societies is important for guiding the use of such methodologies in all IPBES work. Different valuation methodologies will be evaluated according to different visions, approaches and knowledge systems, and their policy relevance based on the diverse conceptualisation of values of biodiversity and nature's benefits to people including provisioning, regulating and cultural services. This assessment will result in a guide, and subsequently promote and catalyse the further development and use of tools and methodologies on these issues. The aim is that such policy support tools will help guide decision-making by taking into account the multiple values of nature and its benefits. 
Box 7. IPBES assessments on land degradation and restoration, invasive alien species, sustainable use, and pollination

Deliverable 3(b)(i): Thematic assessment on land degradation and restoration This assessment covers the global status of and trends in land degradation, by region and land cover type; the effect of degradation on biodiversity values, ecosystem services and human well-being; and the state of knowledge, by region and land cover type, of ecosystem restoration extent and options. The assessment would enhance the knowledge base for policies for addressing land degradation, desertification and the restoration of degraded land.

Deliverable 3(b)(ii): Thematic assessment on invasive alien species and their control

This assessment will assess the threat that invasive alien species pose to biodiversity, ecosystem services and livelihoods and the global status of and trends in impacts of invasive alien species by region and sub-region, taking into account various knowledge and value systems.

Deliverable 3(b)(ii): Thematic assessment on invasive alien species and their control

This assessment will assess the threat that invasive alien species pose to biodiversity, ecosystem services and livelihoods and the global status of and trends in impacts of invasive alien species by region and sub-region, taking into account various knowledge and value systems.

Deliverable 3(b)(iii): Thematic assessment on sustainable use and conservation of biodiversity and strengthening capacities and tools

This assessment will address the ecological, economic, social and cultural importance, conservation status, drivers of change, of mainly harvested and traded biodiversity related products and wild species. It will also assess the potential of the sustainable use of biodiversity for the enhancement of livelihoods of indigenous peoples and local communities, including the role of traditional governance and institutions. It will identify guidelines, methods and tools and promote best practices, including both modern technologies and indigenous and local knowledge, for sustainable management and harvesting. The assessment will contribute to identification of related knowledge gaps and better technologies, including in respect of indigenous and local knowledge. It will also contribute to the development of policy support tools and methodologies, to enhancing sustainable management schemes (including the establishment and management of harvest quotas), to aiding compliance and enforcement measures, and to addressing capacity-building needs in countries of origin. 
Thematic assessment of pollinators, pollination and food production (Deliverable $3 a$ ) The scope of this assessment is to cover changes in animal pollination as a regulating ecosystem service that underpins food production and its contribution to gene flows and restoration of ecosystems. It addresses the role of native and exotic pollinators, the status of and trends in pollinators and pollination networks and services, drivers of change, impacts on human well-being, food production of pollination declines and deficits and the effectiveness of responses to pollination declines and deficits. The assessment is required for enhancing policy responses to declines and deficits in pollination. The assessment represents an early IPBES deliverable that aims to identify policy-relevant findings for decision-making in government, the private sector and civil society, as well as helping to demonstrate how an essential ecosystem service contributes to the post-2015 development agenda.

\section{Box 8. Stakeholder engagement strategy}

The IPBES secretariat has produced a stakeholder engagement strategy that was adopted by the Plenary at IPBES3 (Decision IPBES-3/4, appended file 13).

"Stakeholder engagement has been identified as an important element for the relevance, effectiveness, credibility and overall success of the Platform. The stakeholder engagement strategy differs from the communications strategy in the following respects: while the stakeholder engagement strategy needs to focus on encouraging the participation of scientists and other knowledge holders in the Platform's work and on facilitating the use of the Platform's products, such as its policy support tools, the communications strategy needs to focus on promoting the work of the Platform among key audiences via publications, media relations, special events and other measures."

The strategy contains objectives, definitions of stakeholders, a discussion on incentives and disincentives for stakeholders to engage, a risk analysis, an evaluation plan, and an implementation plan.

"In implementing the stakeholder engagement strategy, it will be useful for the Platform to be aware of potential incentives and disincentives to engagement." "Possible incentives for experts to participate in the work of the Platform [...] include: prestige and opportunities to engage in a project of scientific excellence; making a difference; relevance to their research interests; networking opportunities; working on something that they consider important; being part of an influential organisation; and recognition for grants, scholarships and fellowships. Possible disincentives include: engaging in a process with regard to which 
they have not been involved in developing the questions; heavy time commitments; lack of clarity on how to participate; uncertainty as to how funding incentives are to be established; and lack of recognition by institutions for the contributions made by their scientists."

The first section of the implementation plan deals with the identification and mobilization of stakeholders. The second section outlines a needs analysis, i.e. the needs of stakeholders, that will affect their willingness to participate, and the preferred methods of engagement. The third section deals with actual engagement activities.

\section{Box 9. Communication and outreach strategy}

The IPBES Secretariat has produced a communication and outreach strategy that was adopted by the Plenary at IPBES3 (Decision IPBES-3/4).

"The purpose of all communications activities will be to ensure that the Platform is recognised as a credible, relevant, independent and legitimate platform that produces policy-relevant - but not policy-prescriptive - knowledge products and builds capacity for the use of biodiversity and ecosystem services knowledge in decision-making."

The strategy contains goals and objectives, an audience analysis, draft messages to be conveyed, areas of activity, and an implementation plan. The focus of messages should be to explain the process and its legitimacy, shedding light on such notions as "global consensus", "peer review", "highest-quality science" and others. The strategy will be implemented by the Secretariat.

\section{Box 10. Capacity building under IPBES}

A task force on capacity building has been established by the Plenary of IPBES (Decision IPBES-2/5). The task force has produced a list of priority capacity building needs that was approved by the Plenary at IPBES3 (Decision IPBES3/1). The task forced has been instructed to work with all relevant subsidiary bodies under the Platform in ensuring that these needs are fully addressed. The Plenary envisaged that the resources needed to meet the capacity building needs would come from the Platform trust fund and in-kind contributions.

The list of priority capacity building needs consists of 26 different items, under five different category headings: 
- Enhance the capacity to participate effectively in implementing the Platform work programme.

- Develop the capacity to carry out and use national and regional assessments.

- Develop the capacity to locate and mobilise financial and technical resources.

- Improve the capacity for access to data, information and knowledge.

- Develop the capacity for enhanced and meaningful multi-stakeholder engagement.

\section{Box 11. Conflict of interest policy under IPBES}

A conflict of interest policy was adopted by IPBES3 (Decision-3/3, Annex II). Below some important parts are presented that the Nordic Assessment of Biodiversity and Ecosystem Services will adhere to:

- "The role of the Platform requires that it pay special attention to issues of independence and bias in order to maintain the integrity of, and public confidence in, its products and processes. It is essential that the work of the Platform is not compromised by any conflict of interest for those who execute it."

- "The conflict of interest policy is designed to ensure that potential conflicts of interest [..] are identified, communicated to the Committee on Conflicts of Interest, and managed in order to avoid any adverse impact on the Platform's independence, deliverables and processes, thereby protecting the person or persons concerned, the Platform and the public interest." "Identifying a potential conflict of interest does not automatically mean that a conflict of interest exists."

- Any "circumstances that could lead a reasonable person to question either an individual's objectivity, or whether an unfair advantage has been created, constitute a potential conflict of interest. A 'conflict of interest' refers to any current interest of an individual that could:

- Significantly impair the individual's objectivity in carrying out his or her duties and responsibilities for the Platform.

- Create an unfair advantage for any person or organisation."

- "A distinction is made between 'conflict of interest' and 'bias'. 'Bias' refers to a point of view or perspective that is strongly held regarding a particular issue or set of issues. In the case of author and review teams, bias can and should be managed through the selection of authors and reviewers with a balance of perspectives. It is expected that the Platform's author teams will include individuals with different perspectives and affiliations. Individuals 
or teams of individuals involved in selecting authors should strive for an author team composition that reflects a balance of expertise and perspectives to ensure that the Platform's products are comprehensive and objective and remain neutral with respect to policy. In selecting these individuals, care must be taken to ensure that biases can be balanced, where they exist. In contrast, a 'conflict of interest' refers to a situation as described" above.

- "The policy applies to the senior leadership of the Platform, namely, members of the Bureau, the Multidisciplinary Expert Panel and any other subsidiary bodies contributing to the development of deliverables, authors with responsibility for report content (including report co-chairs, coordinating lead authors and lead authors), review editors and the professional staff to be hired to work in a technical support unit established by the Platform." "The policy applies to the development of any and all deliverables of the Platform."

- "Before an individual is appointed as a task force and expert group member, report co-chair, coordinating lead author, lead author or review editor, the Secretariat will request the individual to complete a conflict of interest form for submission to the Secretariat. The Committee on Conflicts of Interest will then evaluate the form to determine whether the individual may be affected by a potential conflict of interest that cannot be resolved. If the Committee determines that the individual has a conflict of interest that cannot be resolved, the individual will not be eligible to participate in the preparation of the deliverable. The individual may, however, request a review".

- Under IPBES a Committee on Conflicts of Interest has been established for the purpose of implementing the rules and determining conflict of interest cases referred to it by the Bureau of the Platform. 
Box 12. IPBES Definitions related to organisation and rules of procedure (from: IPBES/3/18)

The definitions of terms used under IPBES are as follows:

Governance structures.

"Platform" means the Intergovernmental Science-Policy Platform on Biodiversity and Ecosystem Services.

"Plenary" means the Platform's decision-making body, comprising all the members of the Platform.

"Bureau" refers to the body of elected members of the Bureau of the session of the Plenary as set forth in the rules of procedure for the Plenary of the Platform.

"Multidisciplinary Expert Panel" refers to the subsidiary body established by the Plenary that carries out the scientific and technical functions agreed upon by the Plenary, as articulated in the functions, operating principles and institutional arrangements of the Platform (UNEP/IPBES.MI/2/9, Annex I, Appendix I).

"Session of the Plenary" means any ordinary or extraordinary session of the Platform's Plenary.

\section{Deliverables}

"Reports" means the main deliverables of the Platform, including assessment reports and synthesis reports, their summaries for policymakers and technical summaries, technical papers and technical guidelines.

"Assessment reports" are published assessments of scientific, technical and socioeconomic issues that take into account different approaches, visions and knowledge systems, including global assessments of biodiversity and ecosystem services, regional and subregional assessments of biodiversity and ecosystem services with a defined geographical scope, and thematic or methodological assessments based on the standard or the fast track approach. They are to be composed of two or more sections including a summary for policymakers, an optional technical summary and individual chapters and their executive summaries.

"Synthesis reports" synthesise and integrate materials drawing from assessment reports, are written in a non technical style suitable for policymakers and address a broad range of policy-relevant questions. They are to be composed of two sections: a summary for policymakers; and a full report.

"Summary for policymakers" is a component of any report providing a policy-relevant but not policy-prescriptive summary of that report.

"Technical summary" is a longer detailed and specialised version of the material contained in the summary for policymakers.

"Technical papers" are based on the material contained in the assessment reports and are prepared on topics deemed important by the Plenary. 
"Supporting material" is material that has been prepared for the Platform and may include the following:

- Dialogue reports based on the material generated by discussions, which may include intercultural and inter-scientific dialogue, at the regional and subregional levels, among members of academic, indigenous peoples, local and civil society organisations and which take into account the different approaches, visions and knowledge systems that exist as well as the various views and approaches to sustainable development.

- Reports and proceedings of workshops and expert meetings that are either commissioned or supported by the Platform.

- Software or databases that facilitate the preparation or use of the Platform's reports.

- Policy relevant tools and methodologies that facilitate the preparation or use of the Platform's reports.

- Guidance materials (guidance notes and guidance documents) that assist in the preparation of comprehensive and scientifically sound Platform reports and technical papers.

\section{Clearance processes}

"Validation" of the Platform's reports is a process by which the Multidisciplinary Expert Panel and the Bureau provide their endorsement that the processes for the preparation of Platform reports have been duly followed.

"Acceptance" of the Platform's reports at a session of the Plenary signifies that the material has not been subjected to section-by-section or line-by-line discussion and agreement by the Plenary but nevertheless presents a comprehensive and balanced view of the subject matter.

"Adoption" of the Platform's reports is a process of section by section (and not line-by-line) endorsement, as described in section 3.9, at a session of the Plenary.

"Approval" of the Platform's summaries for policymakers signifies that the material has been subject to detailed, line-by-line discussion and agreement by consensus at a session of the Plenary.

"Preliminary acceptance, adoption and approval" of regional reports will be undertaken by the relevant regional representatives at a session of the Plenary, and such reports will then be further reviewed and may be accepted, adopted and approved by the Plenary as a whole.

Acceptance, adoption and approval are done by consensus. 


\section{Box 13. Preparation of reports under IPBES.}

The main steps, under IPBES, of the procedures for the preparation of a subregional assessment report and summary for policy makers are outlined in section 3.3 of Decision IPBES-3/3, Annex I. Assuming the initial steps of scoping have been completed, the main steps of producing a subregional assessment would be the following:

- $\quad$ The Multidisciplinary Expert Panel will request nominations from governments and invite relevant stakeholders to present names of experts to contribute to the preparation of the report [section 3.6.1].

- The Multidisciplinary Expert Panel will select the report co-chairs, coordinating lead authors, lead authors and review editors using the selection criteria (section 3.6.2) from the lists of nominations, of which experts selected from those presented by relevant stakeholders should not exceed $20 \%$. The Multidisciplinary Expert Panel will, in particular, take into account the views of the Panel members from the relevant region as well as those with experience with the geographic region under consideration [section 3.6.2].

- The report co-chairs, coordinating lead authors and lead authors prepare the first draft of the report [section 3.6.3].

- The first draft of the report is peer reviewed by experts in an open and transparent process. The review of regional and subregional reports will emphasise the use of expertise from, as well as relevant to, the geographic regions under consideration [section 3.6.4].

- The report co-chairs, coordinating lead authors and lead authors prepare the second draft of the report and the first draft of the summary for policymakers with the guidance of the review editors and the Multidisciplinary Expert Panel.

- The second draft of the report and the first draft of the summary for policymakers are reviewed concurrently by both governments and experts in an open and transparent process [section 3.6.4].

- The report co-chairs, coordinating lead authors and lead authors prepare the final drafts of the report and the summary for policymakers with the guidance of the review editors and the Multidisciplinary Expert Panel [section 3.6.4.3, 3.8].

- The summary for policymakers is translated into the six official languages of the United Nations and prior to distribution is checked for accuracy by the experts involved in the assessments.

- The final drafts of the report and the summary for policymakers are sent to Governments for final review and made available on the Platform website. 
- Governments are strongly encouraged to submit written comments on the final draft of the summary for policymakers at least two weeks prior to any session of the Plenary.

- The Plenary reviews and may accept the report and approve the summary for policymakers."

Box 14. Process and timetable for regional and subregional assessments, workplan as agreed in the IPBES

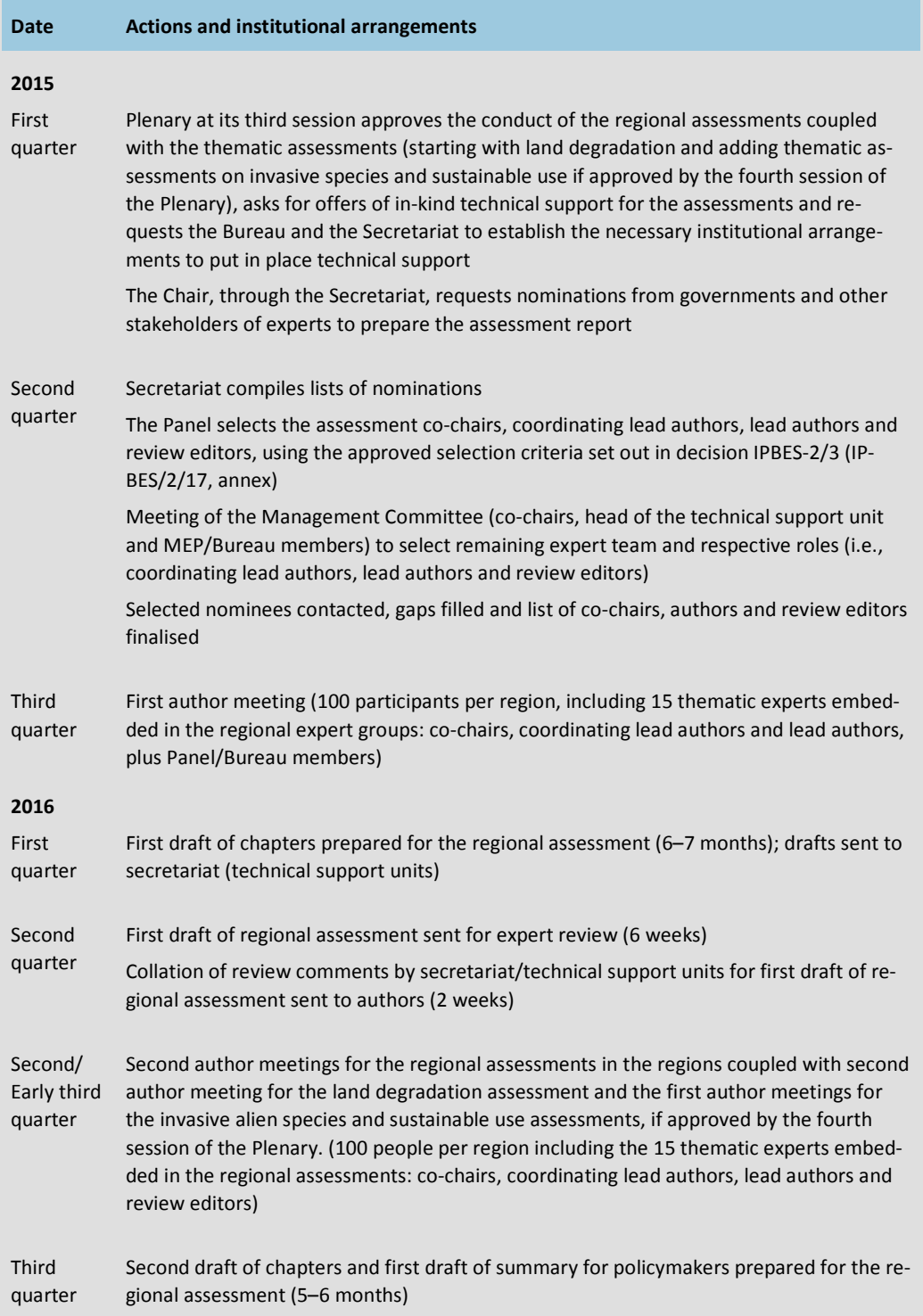

First author meeting (100 participants per region, including 15 thematic experts embed- 
2017

First quarter

Collation of review comments for second draft of the regional assessment and first draft of the summary for policymakers sent to authors ( 2 weeks)

Second Third author meeting for the regional assessment coupled with third author meeting for quarter land degradation and second author meetings for invasive alien species and sustainable use assessments ( 30 participants per region: co-chairs, coordinating lead authors and review editors and Panel/Bureau members)

Third Final text changes to regional assessment and the summary for policymakers ( 3 months) quarter

Translation of summary for policymakers into the six official languages of the United $\mathrm{Na}$ tions (1 month)

Fourth Submission of the regional assessment, including the translated summary for policymakquarter ers, to governments for final review prior to Plenary (6 weeks)

Final government comments on the summary for policymakers for consideration by authors prior to the next Plenary session

2018

January Plenary to approve/accept regional assessments, including the summaries for

2018 policymakers

(To be con-

firmed) 
Box 15. Estimated cost of conducting and preparing the assessment report in one IPBES region

\begin{tabular}{|c|c|c|c|}
\hline Year & Cost item & Assumptions & $\begin{array}{l}\text { Cost (United } \\
\text { States dollars) }\end{array}$ \\
\hline \multirow[t]{5}{*}{2015} & \multirow{2}{*}{$\begin{array}{l}\text { Management committee meeting } \\
\text { ( } 2 \text { co-chairs, head of technical support } \\
\text { unit, secretariat) }\end{array}$} & Meeting costs & 0 \\
\hline & & Travel and DSA ( 3 x USD 3,750$)$ & 11,250 \\
\hline & \multirow{2}{*}{$\begin{array}{l}\text { First authors' meeting (100 co-chairs, } \\
\text { coordinating lead authors and lead } \\
\text { authors) }\end{array}$} & $\begin{array}{l}\text { Meeting costs ( } 1 \text { week, regional, } \\
100 \text { participants) ( } 25 \% \text { in-kind) }\end{array}$ & 18,750 \\
\hline & & Travel and DSA ( $75 \times$ USD 3,000$)$ & 225,000 \\
\hline & Technical support & $\begin{array}{l}2 \text { full-time equivalent professional po- } \\
\text { sitions ( } 50 \% \text { in-kind) }\end{array}$ & 150,000 \\
\hline \multirow[t]{3}{*}{2016} & \multirow{2}{*}{$\begin{array}{l}\text { Second authors' meeting ( } 30 \text { co- } \\
\text { chairs, coordinating lead authors, and } \\
\text { review editors) }\end{array}$} & $\begin{array}{l}\text { Meeting costs ( } 1 \text { week, international, } \\
30 \text { participants) }(25 \% \text { in-kind })\end{array}$ & 11,250 \\
\hline & & Travel and DSA ( $23 \times$ USD 3,750$)$ & 86,250 \\
\hline & Technical support & $\begin{array}{l}2 \text { full-time equivalent professional po- } \\
\text { sitions ( } 50 \% \text { in-kind) }\end{array}$ & 150,000 \\
\hline \multirow[t]{3}{*}{2017} & \multirow{2}{*}{$\begin{array}{l}\text { Third authors' meeting (110 co-chairs, } \\
\text { coordinating lead authors and lead } \\
\text { authors, and review editors) }\end{array}$} & $\begin{array}{l}\text { Meeting costs ( } 1 \text { week, regional, } \\
110 \text { participants) ( } 25 \% \text { in-kind) }\end{array}$ & 18,750 \\
\hline & & Travel and DSA ( $83 \times$ USD 3,000$)$ & 247,500 \\
\hline & Technical support & $\begin{array}{l}2 \text { full-time equivalent professional po- } \\
\text { sitions ( } 50 \% \text { in-kind) }\end{array}$ & 150,000 \\
\hline \multirow[t]{2}{*}{2018} & $\begin{array}{l}\text { Co-chairs' participation in the fifth } \\
\text { session of the Plenary }\end{array}$ & Travel and DSA ( 2 x USD 3,750$)$ & 7,500 \\
\hline & $\begin{array}{l}\text { Dissemination and regional outreach } \\
\text { (summary for policymakers }(3 \times 10 \\
\text { pages) and report ( } 200 \text { pages }))\end{array}$ & $\begin{array}{l}\text { Translation of summaries for policy- } \\
\text { makers into all United Nations lan- } \\
\text { guages, publication and outreach }\end{array}$ & 117,000 \\
\hline Total & & & $1,193,250$ \\
\hline
\end{tabular}




\section{Box 16. Policy support tools and methodologies under IPBES}

In decision IPBES-2/5, IPBES requested the Multidisciplinary Expert Panel and the Bureau, supported as necessary by a task-specific expert group, to develop a catalogue of policy support tools and methodologies (PSTMs) and to provide guidance on how the further development of such tools and methodologies could be promoted and catalysed in the context of IPBES. Accordingly, the Panel and the Bureau established an expert group on PSTM and the 3rd Plenary approved the continuation of this expert group (IPBES/3/18). The outputs of the expert group have been a proposed catalogue on PSTMs, and support in developing preliminary guidance on how the function of policy support could be implemented in the work programme (IPBES/3/5).

PSTMs in the context of IPBES are "approaches and techniques based on science and other knowledge systems (including indigenous and local knowledge) that can inform, assist and enhance relevant decisions, policymaking and implementation at local, national, regional and international levels to protect nature, so promoting nature's benefits to people and a good quality of life" (IPBES Del. 4c, 2015).

The IPBES catalogue on PSTMs, an online platform, aims to be a dynamic community of practice and it is designed to meet the end-users needs, including experts conducting IPBES assessments (IPBES Del. 4c, 2015). It has four entry points which are based on the typology of policy PSTM of Chapter 2 "Definition and typology of policy support tools and methodologies in the context of IPBES" (Deliverable 4c, 2015) and are the following: First, elements of the policy cycle with three distinct but overlapping elements: agenda setting and review; policy design and decisions; and policy implementation. Second, families of tools and methodologies, defined in terms of the broad challenges addressed and with examples of tools and methodologies for each: 1. Assembling data and knowledge (including monitoring); 2. Assessment and evaluation; 3. Public discussion, involvement and participatory process; 4 . Selection and design of policy instruments; 5. Implementation, outreach and enforcement; 6 . Training and capacity building; 7. Social learning, innovation and adaptive governance. Third, the IPBES conceptual framework and associated PSTMs to address various of its elements and dynamics. Fourth, applications for the implementation of Multilateral Environmental Agreements (MEAs) that can contribute to support common MEAs objectives: Strategies, action plans and targets of MEA; Compliance, monitoring and enforcement of MEAs; National reporting of MEAs; Capacity building for implementation of MEAs. 


\section{Annex 8. Aichi Biodiversity Targets}

(http://www.cbd.int/sp/targets/)

Strategic Goal A: Address the underlying causes of biodiversity loss by mainstreaming biodiversity across government and society

Target 1: By 2020, at the latest, people are aware of the values of biodiversity and the steps they can take to conserve and use it sustainably.

Target 2: By 2020, at the latest, biodiversity values have been integrated into national and local development and poverty reduction strategies and planning processes and are being incorporated into national accounting, as appropriate, and reporting systems.

Target 3: By 2020, at the latest, incentives, including subsidies, harmful to biodiversity are eliminated, phased out or reformed in order to minimise or avoid negative impacts, and positive incentives for the conservation and sustainable use of biodiversity are developed and applied, consistent and in harmony with the Convention and other relevant international obligations, taking into account national socio economic conditions.

Target 4: By 2020, at the latest, Governments, business and stakeholders at all levels have taken steps to achieve or have implemented plans for sustainable production and consumption and have kept the impacts of use of natural resources well within safe ecological limits.

Strategic Goal B: Reduce the direct pressures on biodiversity and promote sustainable use

Target 5: By 2020, the rate of loss of all natural habitats, including forests, is at least halved and where feasible brought close to zero, and degradation and fragmentation is significantly reduced.

Target 6: By 2020 all fish and invertebrate stocks and aquatic plants are managed and harvested sustainably, legally and applying ecosystem based approaches, so that overfishing is avoided, recovery plans and measures are in place for all depleted species, fisheries have no significant adverse impacts on threatened species and vulnerable ecosystems and the impacts of fisheries on stocks, species and ecosystems are within safe ecological limits.

Target 7: By 2020 areas under agriculture, aquaculture and forestry are managed sustainably, ensuring conservation of biodiversity. 
Target 8: By 2020, pollution, including from excess nutrients, has been brought to levels that are not detrimental to ecosystem function and biodiversity.

Target 9: By 2020, invasive alien species and pathways are identified and prioritized, priority species are controlled or eradicated, and measures are in place to manage pathways to prevent their introduction and establishment.

Target 10: By 2015, the multiple anthropogenic pressures on coral reefs, and other vulnerable ecosystems impacted by climate change or ocean acidification are minimised, so as to maintain their integrity and functioning.

Strategic Goal C: To improve the status of biodiversity by safeguarding ecosystems, species and genetic diversity

Target 11: By 2020, at least $17 \%$ of terrestrial and inland water, and $10 \%$ of coastal and marine areas, especially areas of particular importance for biodiversity and ecosystem services, are conserved through effectively and equitably managed, ecologically representative and well connected systems of protected areas and other effective area-based conservation measures, and integrated into the wider landscapes and seascapes.

Target 12: By 2020 the extinction of known threatened species has been prevented and their conservation status, particularly of those most in decline, has been improved and sustained.

Target 13: By 2020, the genetic diversity of cultivated plants and farmed and domesticated animals and of wild relatives, including other socio-economically as well as culturally valuable species, is maintained, and strategies have been developed and implemented for minimizing genetic erosion and safeguarding their genetic diversity.

Strategic Goal D: Enhance the benefits to all from biodiversity and ecosystem services

Target 14: By 2020, ecosystems that provide essential services, including services related to water, and contribute to health, livelihoods and wellbeing, are restored and safeguarded, taking into account the needs of women, indigenous and local communities, and the poor and vulnerable.

Target 15: By 2020, ecosystem resilience and the contribution of biodiversity to carbon stocks has been enhanced, through conservation and restoration, including restoration of at least $15 \%$ of degraded ecosystems, thereby contributing to climate change mitigation and adaptation and to combating desertification. 
Target 16: By 2015, the Nagoya Protocol on Access to Genetic Resources and the Fair and Equitable Sharing of Benefits Arising from their Utilisation is in force and operational, consistent with national legislation.

Strategic Goal E: Enhance implementation through participatory planning, knowledge management and capacity building

Target 17: By 2015 each Party has developed, adopted as a policy instrument, and has commenced implementing an effective, participatory and updated national biodiversity strategy and action plan.

Target 18: By 2020, the traditional knowledge, innovations and practices of indigenous and local communities relevant for the conservation and sustainable use of biodiversity, and their customary use of biological resources, are respected, subject to national legislation and relevant international obligations, and fully integrated and reflected in the implementation of the Convention with the full and effective participation of indigenous and local communities, at all relevant levels.

Target 19: By 2020, knowledge, the science base and technologies relating to biodiversity, its values, functioning, status and trends, and the consequences of its loss, are improved, widely shared and transferred, and applied.

Target 20: By 2020, at the latest, the mobilisation of financial resources for effectively implementing the Strategic Plan for Biodiversity 2011-2020 from all sources, and in accordance with the consolidated and agreed process in the Strategy for Resource Mobilisation, should increase substantially from the current levels. This target will be subject to changes contingent to resource needs assessments to be developed and reported by Parties. 



\title{
Annex 9. Abbreviations and Glossary
}

\author{
Abbreviations
}

CBD UN Convention on Biological Diversity.

CBM Swedish Biodiversity Centre.

CICES Common International Classification of Ecosystem Services.

ECA IPBES regional assessment for Europe and Central Asia.

EEA European Economic Area.

EEZ Exclusive Economic Zone.

ESMERALDA The objective of ESMERALDA is to share experience through an active process of dialogue and knowledge cocreation that will enable participants to achieve the Action 5 aims.

FPIC Free prior and informed consent.

GEO Global Environment Outlook.

HELCOM Baltic Marine Environment Protection Commission - Helsinki Commission.

ILK Indigenous and local knowledge.

IMoSEB International Mechanism of Scientific Expertise on Biodiversity.

IPLCs Indigenous peoples and local communities.

IPBES Intergovernmental Science-Policy Platform on Biodiversity and Ecosystem Services.

MA Millennium Ecosystem Assessment.

MAES Mapping and Assessment of Ecosystems and their Services.

MEA Multilateral Environmental Agreement.

MEP Multidisciplinary Expert Panel.

NAPTEK A national programme on local and traditional knowledge concerning the conservation and sustainable use of biological diversity. 
NCM Nordic Council of Ministers.

OSPAR OSPAR is the mechanism by which fifteen Governments of the western coasts and catchments of Europe, together with the European Union, cooperate to protect the marine environment of the North-East Atlantic (named after the original OSlo and PARis conventions).

SAC Special Areas of Conservation.

SBSTTA Subsidiary Body on Scientific, Technical and Technological Advice.

SCB Statistiska Centralbyrån (Statistics Sweden).

SCI Sites of Community Importance.

SEPA Swedish Environmental Protection Agency.

SPA Special Protection Area.

TEEB The Economics of Ecosystems and Biodiversity.

TEG Technical Expert Groups.

UK NEA The UK National Ecosystem Assessment.

VRBM Vetenskapliga rådet för biologisk mångfald och ekosystemtjänster (Swedish Scientific Council on Biodiversity and Ecosystem Services).

WWF World Wide Fund for Nature.

\section{Glossary}

The Glossary is mainly based on Díaz et al. (2015); and Report of the second session of the Plenary of the Intergovernmental Science-Policy Platform on Biodiversity and Ecosystem Services, IPBES/2/17, 9 January 2014. If no other reference is quoted, the above is the reference. Some extra terminology is added, with special reference indicated. It should also be said that several of the concepts could be understood in different ways, and that the definitions of the concepts might have both advantages and disadvantages, and that the concepts need further critical research - to sharpen this analytical tool.

Adaptive cycle: A way of describing the dynamics of social-ecological systems through various phases of organisation and function. Four phases have been identified: rapid growth, conservation, release, and reorganisation. The manner in which the system behaves is different from 
one phase to the next. ${ }^{47}$ Synchronicity of adaptive cycles on larger scales increase the risk for cascading disturbances.

Adaptive management: Management approach that emphasises learning and uses structured experimentation in combination with flexibility to foster learning. ${ }^{48}$

Adaptive co-management: Explicitly links learning (experiential and experimental) and collaboration to facilitate effective governance. ${ }^{49}$

Adaptive Governance: Connects individuals, organisations, agencies, and institutions at multiple organisational levels. Adaptive governance systems often self-organise as social networks with teams and actor groups that form a learning environment to draw on various knowledge systems and experiences to tackle complex environmental issues. ${ }^{50}$

Anthropogenic: of, relating to, or resulting from the influence of human beings on nature. 51

Anthropogenic assets: Built-up infrastructure, health facilities, knowledge (including indigenous and local knowledge systems, and technical or scientific knowledge, as well as formal and non-formal education), technology (both physical objects and procedures), and financial assets among others.

Anthropocentric: interpreting or regarding the world in terms of human values and experiences. ${ }^{52}$

Anthropocene: The Age of Man, a new name for the present geological epoch defined by our own massive impact on the planet's climate and ecosystems. Coined in 2000 by Nobel Laureate Paul Crutzen (Steffen et al., 2011).

Baseline: A minimum or starting point with which to compare other information (e.g. for comparisons between past and present or before and after an intervention).

Biocultural diversity: Biocultural diversity comprises the diversity of life in all of its manifestations: biological, cultural, and linguistic, which are interrelated (and possibly co-evolved) within a complex social-ecological adaptive system. The definition comprises the following key elements: 1 . The diversity of life is made up not only of the diversity of plants and animal species, habitats, and ecosystems found on the planet, but also of the diversity of human cultures and languages; 2 . These diversities do not exist in separate and parallel realms, but rather they interact with and

\footnotetext{
${ }^{47}$ Adapted from Resilience dictionary, http://www.stockholmresilience.org/21/research/ what-is-resilience/resilience-dictionary.html and Walker \& Salt (2012).

${ }^{48}$ Ibid.

49 Ibid.

${ }^{50}$ Ibid.

${ }^{51} \mathrm{http}: / /$ www.merriam-webster.com/dictionary/anthropogenic

$52 \mathrm{http}: / /$ www.merriam-webster.com/dictionary/anthropocentric
} 
affect one another in complex ways; and 3. The links among these diversities have developed over time through mutual adaptation between humans and the environment at the local level, possibly of a co-evolutionary nature (Maffi, 2010).

Biodiversity (contraction of biological diversity): The variability among living organisms from all sources including terrestrial, marine and other aquatic ecosystems and the ecological complexes of which they are a part. This includes variation in genetic, phenotypic, phylogenetic, and functional attributes, as well as changes in abundance and distribution over time and space within and among species, biological communities and ecosystems. ${ }^{53}$

Biological resources: includes genetic resources, organisms or parts thereof, populations, or any other biotic component of ecosystems with actual or potential use or value for humanity. ${ }^{54}$

Biosphere: All the ecosystems of the world considered together. It includes the organisms living on the Earth, the resources they use and the space they occupy on part of the Earth's crust (the lithosphere), in the oceans (the hydrosphere) and in the atmosphere.

Biotechnology: means any technological application that uses biological systems, living organisms, or derivatives thereof, to make or modify products or processes for specific use. ${ }^{55}$

Connectivity: The way and degree to which resources, species, or social actors disperse, migrate, or interact across ecological and social landscapes. ${ }^{56}$

Complex adaptive system (CAS): A system of interconnected components that has the capacity to adapt and self-organise in response to internal or external disturbance or change..$^{57}$

Cosmocentric: A vision of reality that places the highest importance or emphasis on the universe or nature, as opposed to an anthropocentric vision, which strongly focuses on humankind as the most important element of existence.

Cross-scale: A study or process that addresses multiple spatial and/or temporal scales and focuses explicitly on how they interact. ${ }^{58}$

\footnotetext{
53 This definition is very similar to CBDs definition in Article 2. Use of Terms. https://www.cbd.int/ convention/articles/default.shtml?a=cbd-02

${ }^{54}$ CBD Article 2. Use of Terms. https://www.cbd.int/convention/articles/default.shtml?a=cbd-02

55 Ibid.

56 Resilience dictionary, http://www.stockholmresilience.org/21/research/what-is-resilience/

resilience-dictionary.html and Walker \& Salt (2012).

57 Ibid.

58 Ibid.
} 
Domesticated or cultivated species: Species in which the evolutionary process has been influenced by humans to meet their needs. ${ }^{59}$

Drivers: Natural or anthropogenic (human-induced) factor that directly or indirectly causes a change in nature.

Drivers, anthropogenic direct: Direct drivers that are the result of human decisions, namely, of institutions and governance systems and other indirect drivers.

Drivers, direct: Drivers (both natural and anthropogenic) that operate directly on nature (sometimes also called pressures).

Drivers, indirect: Drivers that operate by altering the level, direction or rate of change of one or more direct drivers.

Drivers, institutions and governance and other indirect: The ways in which societies organise themselves. They are the underlying causes of environmental change that are external to the ecosystem in question, on which they operate through direct drivers.

Drivers, natural direct: Direct drivers that are not the result of human activities and are beyond human control.

Ecosystem: A dynamic complex of plant, animal, and micro-organism communities and their non-living environment interacting as a functional unit. ${ }^{60}$ Ecosystems can be defined at a variety of scales, from a single pond to the globe. Humans and their activities are part of ecosystems as well.

Ecosystem functioning: The flow of energy and materials through the arrangement of biotic and abiotic components of an ecosystem. It includes many processes such as biomass production, trophic transfer through plants and animals, nutrient cycling, water dynamics and heat transfer. The concept is used here in the broad sense and it can thus be taken as being synonymous with ecosystem properties or ecosystem structure and function.

Ecosystem services: The benefits (and occasionally losses or detriments) that people obtain from ecosystems. These include provisioning services such as food and water; regulating services such as flood and disease control; and cultural services such as recreation, ethical and spiritual, educational and sense of place. In the original definition of the Millennium Ecosystem Assessment (2005) the concept of "ecosystem goods and services" is synonymous with ecosystem services. Other approaches distinguish "final ecosystem services" that directly deliver welfare gains and/or losses to people through goods from this general term

${ }^{59}$ CBD Article 2. Use of Terms. https://www.cbd.int/convention/articles/default.shtml?a=cbd-02 ${ }^{60}$ Formulated in accordance with CBD Article 2 on Use of Terms. 
that includes the whole pathway from ecological processes through to final ecosystem services, goods and anthropocentric values to people. Added in the Nordic Assessment is consideration of the Common International Classification of Ecosystem Services (CICES).

Ecosystem goods: According to the Millennium Ecosystem Assessment, they are included in the general definition of ecosystem services. According to other approaches, they are objects from ecosystems that people value through experience, use or consumption. The use of this term in the context of this document goes well beyond a narrow definition of goods simply as physical items that are bought and sold in markets, and includes objects that have no market price.

Ethnobiodiversity: The uses, knowledge, beliefs, management systems, taxonomies and language that a given culture has for the biodiversity with which it relates (ecosystems, species and genetic diversity). Ethnobiodiversity is part of biocultural diversity.

$E x$-situ conservation: means the conservation of components of biological diversity outside their natural habitats. ${ }^{61}$

Feedbacks: A mechanism, process, or signal that loops back to influence the social-ecological system component emitting the signal or initiating the mechanism or process. ${ }^{62}$

Functional redundancy: The presence of several species or system elements that can perform the same function and thus compensate for one another. ${ }^{63}$

Genetic material: means any material of plant, animal, microbial or other origin containing functional units of heredity. ${ }^{64}$

Genetic resources: means genetic material of actual or potential value. 65

Good quality of life: The achievement of a fulfilled human life, the criteria for which may vary greatly across different societies and groups within societies. It is a context-dependent state of individuals and human groups, comprising aspects such access to food, water, energy and livelihood security, and also health, good social relationships and equity, security, cultural identity, and freedom of choice and action. "Living in harmony with nature", "living-well in balance and harmony with Mother Earth" and "human well-being" are examples of different perspectives on good quality of life.

\footnotetext{
${ }^{61}$ CBD Article 2. Use of Terms. https://www.cbd.int/convention/articles/default.shtml?a=cbd-02

${ }^{62}$ Resilience dictionary, http://www.stockholmresilience.org/21/research/what-is-resilience/ resilience-dictionary.html and Walker \& Salt (2012).

${ }^{63}$ Adapted from Resilience dictionary, http://www.stockholmresilience.org/21/research/

what-is-resilience/resilience-dictionary.html and Walker \& Salt (2012).

${ }^{64}$ CBD Article 2. Use of Terms. https://www.cbd.int/convention/articles/default.shtml?a=cbd-02

65 Ibid.
} 
Habitat: means the place or type of site where an organism or population naturally occurs. ${ }^{66}$

Human well-being: See well-being.

Indigenous and local knowledge system (ILK): A cumulative body of knowledge, practice and belief, evolving by adaptive processes and handed down through generations by cultural transmission, about the relationship of living beings (including humans) with one another and with their environment. It is also referred to by other terms such as, for example, indigenous, local or traditional knowledge, traditional ecological/environmental knowledge (TEK), farmers' or fishers' knowledge, ethnoscience, indigenous science, folk science.

In-situ conditions: means conditions where genetic resources exist within ecosystems and natural habitats, and, in the case of domesticated or cultivated species, in the surroundings where they have developed their distinctive properties. ${ }^{67}$

In-situ conservation: means the conservation of ecosystems and natural habitats, and the maintenance and recovery of viable populations of species in their natural surroundings and, in the case of domesticated or cultivated species, in the surroundings where they have developed their distinctive properties. ${ }^{68}$.

Institutions: Encompass all formal and informal interactions among stakeholders and social structures that determine how decisions are taken and implemented; how power is exercised; and how responsibilities are distributed. The norms and rules govern human interactions. These can be formal, such as rules and laws, but also informal, such as norms and conventions of society. 69

Knowledge system: A body of propositions that are adhered to, whether formally or informally, and are routinely used to claim truth.

Level of resolution: Degree of detail captured in an analysis. A high level of resolution implies a highly detailed analysis, usually associated with finer spatial and temporal scales. A low level of resolution implies a less detailed analysis, usually associated with coarser spatial and temporal scales.

Living in harmony with nature: A perspective on good quality of life based on the interdependence that exists among human beings, other liv-

\footnotetext{
${ }^{66}$ Ibid.

67 Ibid.

68 Ibid.

${ }^{69}$ Resilience dictionary, http://www.stockholmresilience.org/21/research/what-is-resilience/

resilience-dictionary.html and Walker \& Salt (2012).
} 
ing species and elements of nature. It implies that we should live peacefully alongside all other organisms even though we may need to exploit other organisms to some degree.

Living-well in balance and harmony with Mother Earth: A concept originating in the visions of indigenous peoples worldwide which refers to the broad understanding of the relationships among people, and between people and Mother Earth. The concept of living-well refers to: firstly, balance and harmony of individuals considering both the material and spiritual dimensions; secondly, balance and harmony among individuals taking into account the relationship of individuals with a community; and finally, balance and harmony between human beings and Mother Earth. Living-well means living in balance and harmony with everybody and everything, with the most important aspect being life itself rather than the individual human being. Living-well refers to living in community, in brotherhood, in complementarity; it means a self-sustaining, communitarian and harmonious life.

Modularity: The degree to which components of a system form subgroups of internally well-connected but externally disconnected clusters. ${ }^{70}$

Mother Earth: An expression used in a number of countries and regions to refer to the planet Earth and the entity that sustains all living things found in nature with which humans have an indivisible, interdependent physical and spiritual relationship.

Multi-scale: A study or process that includes two or more different levels of organisation. ${ }^{71}$

Nature: The natural world, with emphasis on the diversity of living organisms and their interactions among themselves and with their environment.

Nature's benefits to people: All the benefits (and occasionally losses or detriments) that humanity obtains from nature.

Non-anthropocentric: an approach towards values in which human beings are part of but not at the centre of ethics. A non-anthropocentric approach values all living and, in some cases, non-living entities such as mountains and stones (Preston, 2003).

Polycentricity: A governance system in which there are multiple interacting governing bodies with autonomy to make and enforce rules within a specific policy arena and geography. ${ }^{72}$

70 Webb, C., \& Bodin, Ö. (2008). A Network Perspective on Modularity and Control of Flow in Robust Systems. In J. Norberg \& G. Cumming (Eds.), Columbia Press.

71 Ibid.

72 Ibid. 
Policy tools: Instruments used by governance bodies at all scales to implement their policies. Environmental policies, for example, could be implemented through tools such as legislation, economic incentives or dis-incentives, including taxes and tax exemptions, or tradable permits and fees.

Protected area: means a geographically defined area which is designated or regulated and managed to achieve specific conservation objectives. ${ }^{73}$

Refugia or resource areas: Biodiversity repositories important for system re-organisation after disturbance. ${ }^{74}$

Regime shift: When a social-ecological system crosses a threshold into a different regime of that system..$^{75}$

Resilience: The capacity of a system - be it a landscape, a coastal area or a city - to deal with change and continue to develop. This means the capacity to withstand shocks and disturbances, such as a financial crisis, or use such an event to catalyse renewal and innovation. ${ }^{76}$

Scale: Extent and/or resolution of a process or analysis, or the level of organisation of a phenomenon or process, e.g. field, farm, region, country. ${ }^{77}$

Scenarios: Plausible alternative future situations based on a particular set of assumptions. Scenarios are associated with lower certainty than projections, forecasts or predictions. For example, socio-economic scenarios are frequently based on storylines describing several alternative, plausible trajectories of population growth, economic growth and per capita consumption, among other things. These are commonly coupled with projections of impacts on biodiversity and ecosystem services based on more quantitative models. The term "scenarios" is sometimes used to describe the outcomes of socio-economic scenarios coupled with models of impacts, owing to the high uncertainty associated with the socio-economic trajectories.

Slow variable: A variable whose rate of change is slow in relation to the timescales of ecosystem service provision and management, and is therefore often considered constant. ${ }^{78}$

Social-ecological system (SES): A coupled system of humans and nature that constitutes a complex adaptive system with ecological and social components that interact dynamically through various feedbacks. ${ }^{79}$

\footnotetext{
${ }^{73}$ CBD Article 2. Use of Terms. https://www.cbd.int/convention/articles/default.shtml?a=cbd-02

${ }^{74}$ A good overview of refugia in Ecology http://www.eoearth.org/view/article/155685/

75 Resilience dictionary, http://www.stockholmresilience.org/21/research/what-is-resilience/

resilience-dictionary.html and Walker \& Salt (2012).

76 Ibid.

${ }^{77}$ Ibid.

${ }^{78}$ Ibid.

${ }^{79}$ Ibid.
} 
Sustainable use: means the use of components of biological diversity in a way and at a rate that does not lead to the long-term decline of biological diversity, thereby maintaining its potential to meet the needs and aspirations of present and future generations. 80

Thresholds: Levels in underlying controlling variables of a system at which feedbacks to the rest of the system change. ${ }^{81}$

Systems of life: The complex, integrated interactions of living beings (including humans), such as the cultural attributes of communities, socioeconomic conditions and biophysical variables.

Trend: The general direction in which the structure or dynamics of a system tends to change, even if individual observations vary.

Values: Those actions, processes, entities or objects that are worthy or important (sometimes values may also refer to moral principles).

Values, biophysical: The value of biological and physical processes and structures in nature. Examples include: structures, such a, vegetation cover; and processes, such as, regulating functions, like the capacity of ecosystems to extract aerosols and chemicals from the atmosphere. Biophysical values contribute to human well-being by maintaining ecosystems and the services derived from them (De Groot et al., 2010). ${ }^{82}$

Values, bequest: The satisfaction of preserving the option of future generations to enjoy nature and its benefits.

Values, existence: The satisfaction obtained from knowing that nature endures.

Values, economic: "Economic literature recognises two broad kinds of values: use value and non-use value. Use values encompass direct consumptive use values such as the value of timber, fish or other resources that ecosystems provide, and direct, non-consumptive use values such as those related to recreation and aesthetic appreciation. Indirect use values relate to the services provided by nature such as air and water purification, erosion prevention and pollination of crops. Non-use value is the importance attributed to an aspect of the environment in addition to, or irrespective of its use values. In essence, it can be understood as the value attributed to the simple existence of the "object" (i.e. its existence value) sometimes also referred to as "insurance value" or "glue value" (Turner et al., 2003)“ (De Groot et al., 2010, p. 262).83

\footnotetext{
${ }^{80}$ CBD Article 2. Use of Terms, https://www.cbd.int/convention/articles/default.shtml?a=cbd-02

${ }^{81}$ Resilience dictionary, http://www.stockholmresilience.org/21/research/what-is-resilience/resiliencedictionary.html and Walker \& Salt (2012).

82 De Groot, Rudolf S., et al. (2010)Challenges in integrating the concept of ecosystem services and values in landscape planning, management and decision making. Ecological Complexity 7.3. P. 260-272.

${ }^{83}$ De Groot, Rudolf S., et al. (2010) Challenges in integrating the concept of ecosystem services and values in landscape planning, management and decision making. Ecological Complexity 7.3. P. 260-272.
} 
Values, instrumental: The direct and indirect contributions of nature's benefits to the achievement of a good quality of life. Within the specific framework of the Total Economic Value, instrumental values can be divided into use (direct and indirect use values) on the one hand, and nonuse values (option, bequest and existence values) on the other. Sometimes option values are also considered as use values.

Value, insurance: Ecosystem resilience, i.e. an ecosystem's ability to maintain its basic functions and controls under disturbances, is often interpreted as insurance (Baumgärtner \& Strunz, 2014).

Values, intrinsic: The values inherent to nature, independent of human judgement, and therefore beyond the scope of anthropocentric valuation approaches.

Values, Non-Instrumental: "A value system in which ecosystems or species have intrinsic rights to a healthful, sustaining condition that is on a par with human rights to satisfaction. The value of any action or object is measured by its contribution to maintaining the health and integrity of an ecosystem or species, per se, irrespective of human satisfaction." (Farber et al., 2002, p376). ${ }^{84}$

Values, option: The potential ability to use some nature's benefits in the future, although they are not currently used or the likelihood of their future use is low. It represents the willingness to preserve an option for future enjoyment of known or yet unknown nature's benefits. The "option values of biodiversity", that is, the value of maintaining living variation in order to provide possible future uses and benefits, often used within the context of conservation biology, is included in this broad concept.

Values, relational: The values that are imbedded in desirable (sought after) relationships, including those among people and between people and nature; because such relationships are valued regardless of whether they imply trade-offs to obtain nature's benefits, relational values depart from economic valuation frameworks.

Values, Socio-cultural: These are values indicating the importance people give to cultural identity for example and how and to what degree it relates to ecosystem services (De Groot et al., 2010). ${ }^{85}$

Value systems: Set of values according to which people, societies and organisations regulate their behaviour. Value systems can be identified in individuals and social groups and thus families, stakeholder groups and ethnic groups may be characterised by specific value systems.

\footnotetext{
${ }^{84}$ Farber, S. C., Costanza, R., \& Wilson, M. A. (2002). Economic and ecological concepts for valuing ecosystem services. Ecological economics 41.3. P. 375-392.

85 De Groot, Rudolf S., et al. (2010). Challenges in integrating the concept of ecosystem services and values in landscape planning, management and decision making. Ecological Complexity 7.3. P. 260-272.
} 
Well-being: A perspective on a good life that comprises access to basic materials for a good life, freedom and choice, health and physical well-being, good social relations, security, peace of mind and spiritual experience.

Western science: (Also called modern science, Western scientific knowledge or international science) is used in the context of the CF as a broad term to refer to knowledge typically generated in universities, research institutions and private firms following paradigms and methods typically associated with the "scientific method" consolidated in post-Renaissance Europe on the basis of wider and more ancient roots. It is typically transmitted through scientific journals and scholarly books. Some of its central tenets are observer independence, replicable findings, systematic scepticism, and transparent research methodologies with standard units and categories. 
norden

Nordic Council of Ministers

Ved Stranden 18

DK-1061 Copenhagen K

www.norden.org

\section{Framing a Nordic IPBES-like study}

Natural resource depletion and adverse impacts from environmental degradation, including loss of biodiversity and ecosystem services and their associated knowledge, add to and exacerbate the list of challenges which humanity faces.

In order to address these challenges, policy makers need credible and independent information that take into account the complex relationships between biodiversity, ecosystem services and people. To meet these needs the "Intergovernmental Science-Policy Platform on Biodiversity and Ecosystem Services" (IPBES) was established in 2012. Its purpose is to assess the state of the planet's biodiversity, its ecosystems and essential services they provide for human wellbeing. This report is the result of an introductory and scoping study, laying the foundation for a Nordic Assessment of Biodiversity and Ecosystem Services based on IPBES methods and procedures.

TemaNord 2016:525

ISBN 978-92-893-4564-4 (PRINT)

ISBN 978-92-893-4565-1 (PDF)

ISBN 978-92-893-4566-8 (EPUB)

ISSN 0908-6692

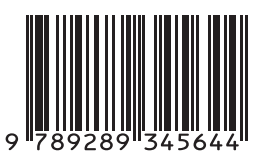

